This article was published in Renewable and Sustainable Energy Reviews, 42, $1187-1213,2015$

http://dx.doi.org/10.1016/j.rser.2014.10.084

\title{
Challenges and Strategies for Optimization of Glycerol Steam Reforming Process
}

Joel M. Silva ${ }^{1}$, M. A. Soria ${ }^{1, *}$, Luis M. Madeira ${ }^{1, *}$

1 LEPABE, Department of Chemical Engineering, Faculty of Engineering, University of Porto, Rua Dr. Roberto Frias s/n, 4200-465 Porto, Portugal

* Corresponding Authors. masoria@fe.up.pt (MA Soria) and +351-225081519 / mmadeira@fe.up.pt (LM Madeira) 


\section{Abstract}

The steam reforming of the main biodiesel by-product, glycerol, has been catching up the interest of the scientific community in the last years. The use of glycerol for hydrogen production is an advantageous option not only because glycerol is renewable but also because it's use would lead to the decrease of the price of biodiesel, thus making it more competitive. Consequently, the use of biodiesel at large scale would significantly reduce $\mathrm{CO}_{2}$ emissions comparatively to fossil fuels. Moreover, hydrogen itself is seen as a very attractive clean fuel for transportation purposes. Therefore, the industrialization of the glycerol steam reforming (GSR) process would have a tremendous global environmental impact. In the last years, intensive research regarding GSR thermodynamics, catalysts, reaction mechanisms and kinetics, and innovative reactor configurations (sorption enhanced reactors (SERs) and membrane reactors (MRs)) has been done, aiming for improving the process effectiveness. In this review, the main challenges and strategies adopted for optimization of GSR process are addressed, namely the GSR thermodynamic aspects, the last developments on catalysis and kinetics, as well as the last advances on GSR performed in SERs and MRs.

Keywords: glycerol; steam reforming; catalyst; kinetics; sorption enhanced reactor; membrane reactor. 


\section{Table of Contents}

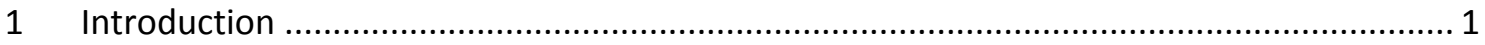

2 Thermodynamics of GSR - Influence of different parameters …....................................... 3

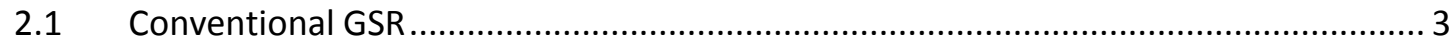

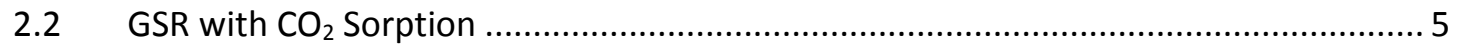

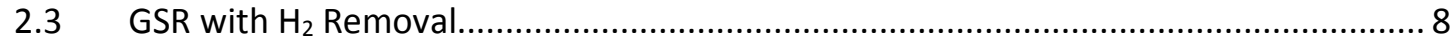

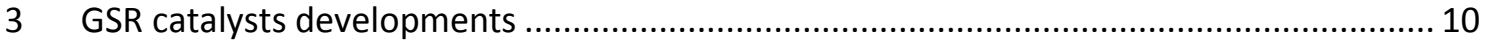

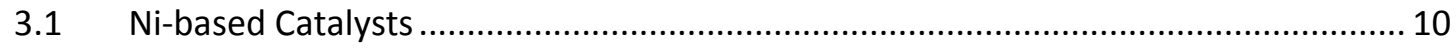

3.1.1 Effect of the support on the catalytic performance........................................ 10

3.1.2 Effect of the addition of a promoter on the catalytic performance ................... 12

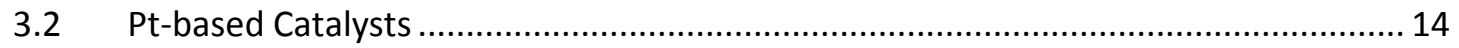

3.2.1 Effect of the support on the catalytic performance........................................... 14

3.2.2 Effect of the addition of a promoter on the catalytic performance .................... 16

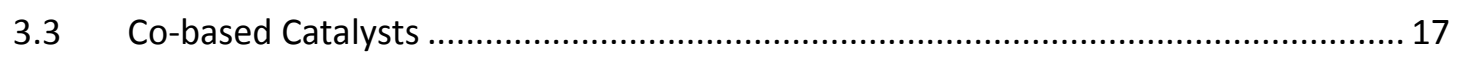

3.3.1 Effect of the support on the catalytic performance........................................ 17

3.3.2 Effect of the addition of a promoter on the catalytic performance .................... 17

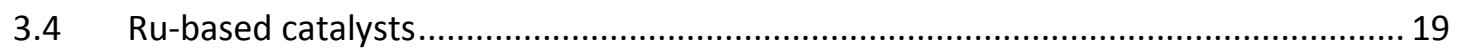

3.4.1 Effect of the support on the catalytic performance ......................................... 19

3.4.2 Effect of the addition of a promoter on the catalytic performance ................... 20

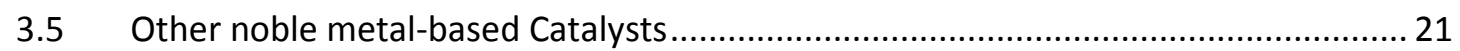

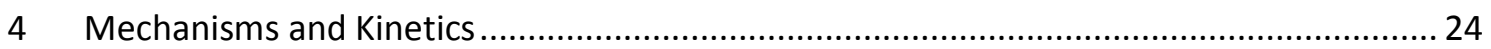

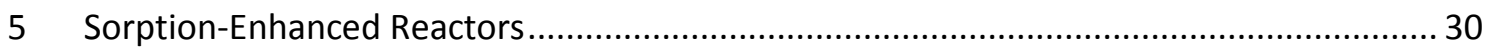

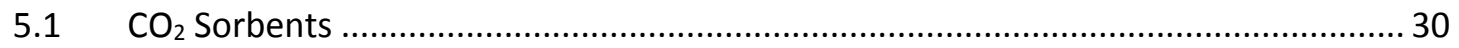

5.2 Sorption Enhanced Glycerol Steam Reforming ....................................................... 32

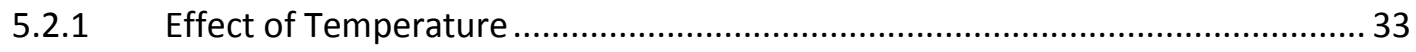

5.2.2 Effect of the Water/Glycerol Feed Ratio .............................................................. 34

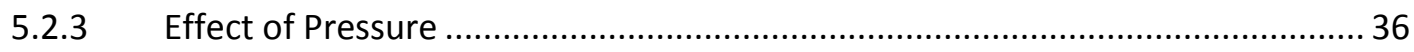

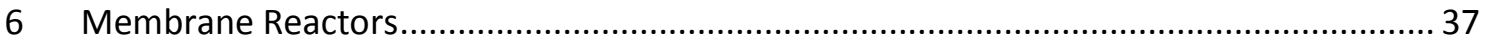

6.1 Hydrogen perm-selective membranes for membrane reactors ............................... 37

6.2 Glycerol Steam Reforming in Membrane Reactors................................................. 39

6.2.1 Effects of Temperature, Pressure and weight hourly space velocity.................. 39

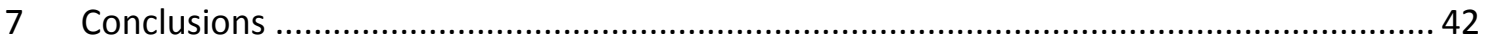

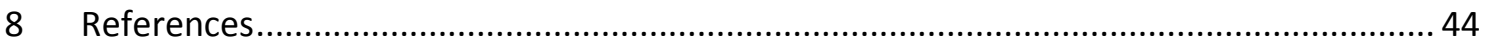




\section{Notation and Glossary}

$\begin{array}{ll}E_{a} & \text { Activation energy } \\ E_{a, P d} & \text { Activation energy of a Pd-based membrane } \\ f & \text { Fraction of } \mathrm{H}_{2} \text { removal } \\ G & \text { Gibbs free energy } \\ J_{H_{2}} & \text { Flux of } \mathrm{H}_{2} \text { through the membrane } \\ K & \text { Equilibrium constant } \\ k & \text { Reaction rate constant } \\ K_{i} & \text { Adsorption constant of component } i \\ k_{0} & \text { Pre-exponential factor } \\ k_{C} & \text { Coke deposition reaction rate constant } \\ n_{i} & \text { Molar number of component } i \\ p_{H_{2}, \text { permeate }} & \text { Partial pressure of } \mathrm{H}_{2} \text { in the permeate side } \\ p_{H_{2}, \text { retentate }} & \text { Partial pressure of } \mathrm{H}_{2} \text { in the retentate side } \\ p_{i} & \text { Partial pressure of component } i \\ P_{P d, H_{2}} & \text { Permeability of a Pd-based membrane to } \mathrm{H}_{2} \\ P_{P d, H_{2}}^{0} & \text { Pre-exponential factor } \\ R & \text { Ideal gas constant } \\ r_{\text {coke deposition }} & \text { Reaction rate of coke deposition } \\ r_{G S R} & \text { Reaction rate of glycerol steam reforming } \\ T & \text { Absolute temperature } \\ X_{1}, X_{2} & \text { Basic and acid active sites, respectively }\end{array}$

\section{Greek letters}

$\begin{array}{ll}\delta & \text { Membrane thickness } \\ \Delta H^{0} & \text { Standard enthalpy } \\ \Delta H_{r}^{298 \mathrm{~K}} & \text { Reaction enthalpy at } 298 \mathrm{~K} \\ \mu_{i} & \text { Chemical potential of component } i\end{array}$

\section{Superscripts}
$a, b$
$x$
Partial reaction orders for glycerol and steam, respectively
Pressure exponent

\section{List of acronyms}

$\begin{array}{ll}\text { CTAB } & \text { Cetyltrimethyl Ammonium Bromide } \\ \text { CVD } & \text { Chemical Vapor Deposition } \\ \text { EP } & \text { Electroless Plating } \\ \text { GHSV } & \text { Gas Hourly Space Velocity } \\ \text { GSR } & \text { Glycerol Steam Reforming } \\ \text { IUPAC } & \text { International Union of Pure and Applied Chemistry } \\ \text { MR } & \text { Membrane Reactor } \\ \text { PEMFC } & \text { Polymer Electrolyte Membrane Fuel Cell } \\ \text { PSA } & \text { Pressure Swing Adsorption } \\ \text { PSS } & \text { Porous Stainless Steel } \\ \text { SEGSR } & \text { Sorption-Enhanced Glycerol Steam Reforming } \\ \text { SER } & \text { Sorption-Enhanced Reactor } \\ \text { SRM } & \text { Steam Reforming of Methane } \\ \text { TR } & \text { Traditional Reactor } \\ \text { WGFR } & \text { Water/Glycerol Feed Ratio (molar) }\end{array}$


WGS

WHSV

Water-Gas Shift

YSZ

Weight Hourly Space Velocity

Yttria-Stabilized Zirconia 


\section{Introduction}

Biodiesel is a promising alternative energy source because it is a renewable fuel and reduces greatly $\mathrm{CO}_{2}$ emissions compared to fossil fuels (Fig.1). The production of biodiesel is most commonly done through transesterification with methanol of triglycerides extracted from sunflower oils, soybean and rapeseed (Fig. 2). This process produces glycerol as the main by-product (100 kg of glycerol/tone of biodiesel) [1, 2]. Moreover, the annual worldwide production of biodiesel has been in an increasing trend lately, as can be seen in Fig. 3 [3]. However, biodiesel is not competitive in terms of price yet [4]. One way of lowering the production cost of biodiesel would be to use its main by-product, glycerol, to produce $\mathrm{H}_{2}$ (or syngas) via steam reforming, for example, thus providing an extra value to such a waste.

Hydrogen is a clean energy source with numerous uses and its demand is expected to greatly increase in the future, mainly due to the technological advancements in the fuel cell industry. Nowadays, nearly $48 \%$ of the worldwide produced hydrogen is generated through the steam reforming of methane (SRM), while the reforming of naphtha/oil contributes with $30 \%$, the coal gasification with $18 \%$ and electrolysis with only 3.9\% [5]. The SRM, in particular, consists of $\mathrm{CH}_{4}$ reacting with $\mathrm{H}_{2} \mathrm{O}$ to yield syngas at high temperatures $\left(700-1100{ }^{\circ} \mathrm{C}\right)$ [4]. Stoichiometrically, 3 moles of $\mathrm{H}_{2}$ can be obtained per mole of methane through SRM, while 7 moles of $\mathrm{H}_{2}$ can be extracted from $1 \mathrm{~mol}$ of glycerol through glycerol steam reforming (GSR), as presented in eq. (1).

$$
\mathrm{C}_{3} \mathrm{H}_{8} \mathrm{O}_{3}+3 \mathrm{H}_{2} \mathrm{O} \leftrightarrow 7 \mathrm{H}_{2}+3 \mathrm{CO}_{2} \quad\left(\Delta H_{r}^{298 K}=128 \mathrm{~kJ} \cdot \mathrm{mol}^{-1}\right)
$$

Furthermore, while for SRM a fuel $\left(\mathrm{CH}_{4}\right)$ is consumed to produce another fuel, the same thing does not happen for GSR. Therefore, the use of glycerol instead of methane would be advantageous [4]. Even though steam reforming is the main target of focus in this review, there are other methods to convert glycerol into $\mathrm{H}_{2}$ :

- Auto-thermal reforming [6-8];

- Partial oxidation gasification [9-11];

- Aqueous-phase reforming [12-14];

- Supercritical water reforming [15-17].

The reason why GSR was chosen as focus of study instead of any of the other processes is mainly due to the fact that the steam reforming process is widely used in industry and it would not require many changes in the system if the feedstock was changed from natural gas or naphtha to glycerol [4]. 
The GSR process, like any other process, has some challenges that need to be overcome in order to accomplish its effective commercialization. Some of the main challenges are:

- The GSR is an endothermic reaction, thus requiring high temperatures and inherently high operating costs. Furthermore, more resistant reactors would be needed and so higher capital costs would be involved;

- The GSR process has side reactions, which affect both production and purity of $\mathrm{H}_{2}$. The main side reactions represented by eq. (2, 3 and 4) lead to methane formation either by reaction of carbon monoxide and hydrogen or reaction of carbon dioxide and hydrogen or through hydrogenolysis of glycerol, respectively.

$$
\begin{array}{lc}
\mathrm{CO}+3 \mathrm{H}_{2} \leftrightarrow \mathrm{CH}_{4}+\mathrm{H}_{2} \mathrm{O} & \left(\Delta \mathrm{H}_{r}^{298 \mathrm{~K}}=-206 \mathrm{~kJ} \cdot \mathrm{mol}^{-1}\right) \\
\mathrm{CO}_{2}+4 \mathrm{H}_{2} \leftrightarrow \mathrm{CH}_{4}+2 \mathrm{H}_{2} \mathrm{O} & \left(\Delta H_{r}^{298 \mathrm{~K}}=-165 \mathrm{~kJ} \cdot \mathrm{mol}^{-1}\right) \\
\mathrm{C}_{3} \mathrm{H}_{8} \mathrm{O}_{3}+2 \mathrm{H}_{2} \leftrightarrow 2 \mathrm{CH}_{4}+\mathrm{CO}+2 \mathrm{H}_{2} \mathrm{O} \quad\left(\Delta H_{r}^{298 \mathrm{~K}}=-160 \mathrm{~kJ} \cdot \mathrm{mol}^{-1}\right)
\end{array}
$$

- Although 7 moles of hydrogen should theoretically be produced per each mole of glycerol that reacts, many authors have observed upper $\mathrm{H}_{2}$ yield limits lower than 7 [18-23];

- The GSR is a thermodynamically-limited reaction (eq. (1)), being inherently the conversion detrimentally affected in certain conditions, particularly at lower temperatures [24];

- The formation of coke is also an issue since it deactivates the catalyst, thus affecting $\mathrm{H}_{2}$ yield and purity and long term operation;

- Besides producing hydrogen the GSR reaction also produces carbon dioxide, whose release is target of environmental concern and restricted by legislation. With the aim of addressing these problems, new catalysts have been developed and different purification methods have been studied. Moreover, new reactor configurations combining the GSR reaction and hydrogen or carbon dioxide selective removal have also been target of intense research, due to their potential to solve some of the limitations previously mentioned. In this review some of the important developments regarding the GSR reaction (including thermodynamics, developed catalysts and reaction kinetics) and its combination with a hydrogen perm-selective

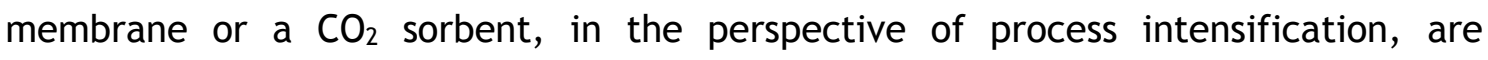
reviewed. Up to the authors' knowledge, a review that conjugates a literature survey of all these subjects is still missing. 


\section{Thermodynamics of GSR - Influence of different parameters}

\subsection{Conventional GSR}

The GSR is an equilibrium-limited process, as previously mentioned, that involves the decomposition of glycerol followed by the water-gas shift (WGS) reaction:

$$
\begin{array}{ll}
\mathrm{C}_{3} \mathrm{H}_{8} \mathrm{O}_{3} \rightleftharpoons 3 \mathrm{CO}+4 \mathrm{H}_{2} & \left(\Delta H_{r}^{298 \mathrm{~K}}=251 \mathrm{~kJ} \cdot \mathrm{mol}^{-1}\right) \\
\mathrm{CO}+\mathrm{H}_{2} \mathrm{O} \rightleftharpoons \mathrm{H}_{2}+\mathrm{CO}_{2} & \left(\Delta H_{r}^{298 \mathrm{~K}}=-41 \mathrm{~kJ} \cdot \mathrm{mol}^{-1}\right)
\end{array}
$$

In order to maximize the production of hydrogen, one must first fully understand how the thermodynamic boundaries are influenced by the different parameters.

There are several studies focused on the thermodynamics of the GSR [24-31]. One of the most important parameters affecting any reaction system is temperature. Once glycerol decomposition is highly endothermic and requires more heat than that produced in the WGS reaction, the overall GSR process is endothermic (eq. (1)), thus meaning that higher temperatures benefit the $\mathrm{H}_{2}$ production (glycerol conversion, $\mathrm{H}_{2}$ yield and selectivity) (Fig. 4) [24]. Mathematically, the equilibrium of a system at constant pressure and temperature is given as follows:

$$
d G=\sum_{i=1}^{K} \mu_{i} d n_{i}=0
$$

where $G$ is the Gibbs free energy, $\mu_{i}$ is the chemical potential of component $i$ and $n_{i}$ is the number of moles of component $i$ in the system. The goal is to determine the set of $n_{i}$ values that minimize de value of $G$ (thermodynamic equilibrium). There are two different thermodynamic approaches that can be used to solve this: (i) stoichiometric [30, 32, 33] and (ii) nonstoichiometric [24-28, 31, 34-38]. By using the stoichiometric approach a set of stoichiometrically independent reactions, which are normally chosen arbitrarily from a set of possible reactions, is used to describe the system. Instead, if the nonstoichiometric method is used the equilibrium composition is calculated based on the direct minimization of the Gibbs free energy of a specific set of species [27]. Both methods have their own advantages, however there has been a significant tendency towards the nonstoichiometric one. In fact, the use of the latter does not require a selection of the possible set of 
reactions. Moreover, during computation there is no divergence and there is no need of an accurate initial estimation of the equilibrium composition [27].

Since the GSR is an endothermic process $\left(\Delta H^{0}>0\right)$, if higher temperatures are used more hydrogen is produced, thus confirming the trend in Fig. 4. Furthermore, a variation of the number of moles of all products $\left(\mathrm{H}_{2}, \mathrm{CO}, \mathrm{CO}_{2}\right.$ and $\left.\mathrm{CH}_{4}\right)$ with temperature is also observed in this figure. At lower temperatures, the formation of $\mathrm{H}_{2}, \mathrm{CO}_{2}$ and $\mathrm{CH}_{4}$ as main products is seen. This might be due to the fact that the exothermic WGS and methane formation reactions are mainly favored at low temperatures. In contrast, endothermic reactions like GSR and reverse WGS are more favored at higher temperatures. This could explain the increase of both $\mathrm{H}_{2}$ and $\mathrm{CO}$ contents and the small decrease of $\mathrm{CO}_{2}$ observed at those temperatures. In any case, an optimum high temperature is normally determined. However, higher temperatures are not favorable from the economic point of view and so alternative ways to attain high $\mathrm{H}_{2}$ production yields have to be considered.

The molar water/glycerol feed ratio (WGFR) has also been found to highly influence the production of $\mathrm{H}_{2}$ (mainly the $\mathrm{H}_{2}$ yield and selectivity) in the equilibrium. Considering the Le Chatelier's principle, it is expectable that for higher WGFRs the equilibrium shifts towards the consumption of the excess of water, thus producing more hydrogen. Such a behavior has been indeed verified and, as can be seen in Fig. 5, the $\mathrm{H}_{2}$ yield increases as the WGFR increases from 4 to 15, whatever the temperature. For WGFRs above 9 the $\mathrm{H}_{2}$ yield increases at a slower rate, especially at higher temperatures. However, the amount of water used should not be too high due to the excessive vaporization costs that it would bring at industrial scale. Moreover, it should be chosen taking into consideration the $\mathrm{H}_{2} \mathrm{O}$ activation capacity of the catalyst used and the other operating conditions (temperature and pressure).

The influence of both operation temperature and WGFR on the formation of coke has been investigated as well [25, 28, 39]. Adhikari et al. [28] suggest that carbon formation may happen through the following reactions:

$$
\begin{aligned}
& 2 \mathrm{CO}(\mathrm{g}) \leftrightarrow \mathrm{CO}_{2}(\mathrm{~g})+\mathrm{C}(\mathrm{s}) \\
& \mathrm{CH}_{4}(\mathrm{~g}) \leftrightarrow 2 \mathrm{H}_{2}(\mathrm{~g})+\mathrm{C}(\mathrm{s}) \\
& \mathrm{CO}(\mathrm{g})+\mathrm{H}_{2}(\mathrm{~g}) \leftrightarrow \mathrm{H}_{2} \mathrm{O}(\mathrm{g})+\mathrm{C}(\mathrm{s})
\end{aligned}
$$




$$
\mathrm{CO}_{2}(\mathrm{~g})+2 \mathrm{H}_{2}(\mathrm{~g}) \leftrightarrow 2 \mathrm{H}_{2} \mathrm{O}(\mathrm{g})+\mathrm{C}(\mathrm{s})
$$

Fig. 6 [25] shows that, in order to avoid carbon formation, which poisons the catalysts, high WGFRs and temperatures should be used. In fact, for WGFRs higher than 5, carbon formation is completely inhibited for all the temperature range considered (550-1000 K). These results are in line with those obtained by Adhikhari et al. [28] and Authayanun et al. [39].

Pressure is also an important parameter because it has a significant influence on the performance of reaction systems. That influence is even more noticeable for processes during which there is variation of the total number of moles, like the GSR, since it affects the thermodynamic equilibrium (Le Chatelier's principle). For the case of GSR, higher pressures lead to a lower hydrogen production in the equilibrium. Moreover, enhanced formation of methane has also been verified [25, 28-30]. Therefore, it results to be advantageous to use lower pressures not only because it is economically more attractive (as far as the pressure is not too low) but also because it leads, under equilibrium, to higher $\mathrm{H}_{2}$ production (Fig. 7) [26]. Pressures lower than the atmospheric pressure would be desired, however, these pressures are more difficult to attain under economically attractive conditions in industrial practice. An alternative way to achieve this would be to use a carrier gas to dilute the reactants, thus decreasing their partial pressures. Chen et al. [26] came to the conclusion that by increasing the amount of carrier gas, not only the maximum $\mathrm{H}_{2}$ production increased but also the optimum temperature dropped. Although it may seem a good solution, at industrial scale it is not so attractive since it would require complex separation processes after the reactor.

In sum, it is clear that high temperatures, high WGFRs and low pressures favor hydrogen production in the equilibrium. Temperatures between $580-702{ }^{\circ} \mathrm{C}$, WGFRs between 9-12 and atmospheric pressure have been reported in the literature as optimum conditions [25-27, 29].

\subsection{GSR with $\mathrm{CO}_{2}$ Adsorption}

It is clear that even at favorable conditions, the GSR equilibrium is still quite limiting in terms of $\mathrm{H}_{2}$ yield, for example. For the cases analyzed in the previous section, the maximum $\mathrm{H}_{2}$ yields observed were close to 6 , due to the co-existence of several reaction apart GSR. However, according to the GSR reaction stoichiometry (eq. (1)), a maximum 
$\mathrm{H}_{2}$ yield close to 7 can be obtained. Such a yield could be reached by performing GSR simultaneously with $\mathrm{CO}_{2}$ capture, since the selective removal of $\mathrm{CO}_{2}$ shifts the thermodynamic equilibrium towards higher $\mathrm{H}_{2}$ yields. The Sorption Enhanced Glycerol Steam Reforming (SEGSR) process also allows to work at milder operating conditions, thus leading to lower operation costs. Moreover, since the emissions of $\mathrm{CO}_{2}$ are diminished, the SEGSR can be considered as a good solution as long as there is a way to store/valorize captured $\mathrm{CO}_{2}$ [40]. In this section a review of some thermodynamic studies on SEGSR is done.

Different approaches have been used to account for $\mathrm{CO}_{2}$ sorption in thermodynamic simulations. Wang et al. [41] accounted for 17 species in SEGSR among which 13 were gases and 4 were solids. These solids include carbon, $\mathrm{CaO}, \mathrm{CaCO}_{3}$ and $\mathrm{Ca}(\mathrm{OH})_{2}$. It is assumed that, in the presence of a $\mathrm{CO}_{2}$ sorbent like $\mathrm{CaO}$, the following reactions take place:

$$
\begin{aligned}
& \mathrm{CaO}(\mathrm{s})+\mathrm{CO}_{2}(\mathrm{~g}) \leftrightarrow \mathrm{CaCO}_{3}(\mathrm{~s}) \\
& \mathrm{CaO}(\mathrm{s})+\mathrm{H}_{2} \mathrm{O}(\mathrm{g}) \leftrightarrow \mathrm{Ca}(\mathrm{OH})_{2}(\mathrm{~s}) \\
& \mathrm{Ca}(\mathrm{OH})_{2}(\mathrm{~s})+\mathrm{CO}_{2}(\mathrm{~g}) \leftrightarrow \mathrm{CaCO}_{3}(\mathrm{~s})+\mathrm{H}_{2} \mathrm{O}
\end{aligned}
$$

In Fig. 8 [41] the effect of temperature and WGFR on the equilibrium concentration of $\mathrm{H}_{2}$ (dry basis) during (a) GSR and (b) SEGSR is presented. For the first case, the observed behavior is very similar to what has already been discussed in the previous section. Regarding the SEGSR, it can be observed that for increasing WGFR values, at constant temperature, the equilibrium hydrogen concentration also increases for the reason stated before. Therefore a balance should be sought, being that a value of 9 is proposed by Chen et al. [42] and Silva et al. [43] as the most favorable for hydrogen production. In terms of temperature, a more noticeable effect is observed. While for temperatures between 500 $900 \mathrm{~K}$ and constant WGFR there is an increase of the equilibrium hydrogen concentration, for temperatures above $900 \mathrm{~K}$ this concentration decreases. The authors suggest that the increase of the $\mathrm{H}_{2}$ concentration up to $900 \mathrm{~K}$ is associated to the compromise between eq. $(2,5,6,12$, and 13). The decrease of the equilibrium hydrogen concentration observed thereafter is due to the fact that the $\mathrm{CO}_{2}$ sorption described by eq. (12) is inhibited due to its exothermic nature. By comparing Fig. 8 (a) and (b), it is clear that the removal of $\mathrm{CO}_{2}$ during reaction enhances $\mathrm{H}_{2}$ production (Le Chatelier's principle), especially at lower 
temperatures where $\mathrm{CO}_{2}$ sorption is more intense. Chen et al. [42] observed that, while without $\mathrm{CO}_{2}$ capture the maximum $\mathrm{H}_{2}$ yield, at WGFR of 9 and $1 \mathrm{~atm}$, was $6, \mathrm{H}_{2}$ yields of approximately 6.5 and 7 were obtained when $80 \%$ and $99 \%$ of the $\mathrm{CO}_{2}$ was removed, respectively. Moreover, the increment of $\mathrm{H}_{2}$ production due to $\mathrm{CO}_{2}$ removal is higher for lower temperatures, which is related with the fact that lower temperatures favor $\mathrm{CO}_{2}$ capture.

Regarding the variation of the concentration of $\mathrm{CO}_{2}$, Wang et al. [41] observed very similar behavior between GSR and SEGSR at temperatures above $900 \mathrm{~K}$. However, at temperatures below $900 \mathrm{~K}$ the $\mathrm{CO}_{2}$ concentration was much lower in the SEGSR due to the already mentioned enhanced sorption, despite the higher $\mathrm{CO}_{2}$ production (Le Chatelier's principle). On the other hand, the production of both methane and carbon monoxide is lower in the SEGSR.

Chen et al. [44] varied the operation pressure between 1-20 atm and analyzed its effect on both GSR and SEGSR in terms of hydrogen yield. The first thing that the authors noticed was that the $\mathrm{H}_{2}$ yield decreased with increasing pressures for both processes. However, the SEGSR was less sensitive to pressure than GSR. This happens because, even though higher pressures do not favor SEGSR but methanation instead, higher pressures enhance $\mathrm{CO}_{2}$ adsorption. For this reason, the negative effects of pressure are diminished during SEGSR, being that the increment in the production of $\mathrm{H}_{2}$ due to $\mathrm{CO}_{2}$ removal is more noticeable at higher pressures.

The sorbent/glycerol ratio is also an important parameter to be taken into consideration. The concentration of $\mathrm{H}_{2}$ increases for increasing $\mathrm{CaO} /$ glycerol ratios, while the concentrations of both $\mathrm{CO}$ and $\mathrm{CO}_{2}$ highly decrease [41]. The concentration of methane presents a maximum. However, for increasing $\mathrm{CaO} /$ glycerol molar ratios above 10 , there is almost no variation of $\mathrm{H}_{2}, \mathrm{CO}, \mathrm{CO}_{2}$ and $\mathrm{CH}_{4}$ concentrations. Therefore, 10 may be considered the optimum $\mathrm{CaO} /$ glycerol molar ratio.

Finally, the deposition of carbon has also been target of investigation. As already discussed for GSR, high temperatures and WGFRs inhibit coke formation. Wang and coauthors observed higher carbon deposition in GSR than in SEGSR. Therefore it can be concluded that the capture of $\mathrm{CO}_{2}$ inhibits coke formation. This is supported by the lower concentrations of $\mathrm{CO}$ and $\mathrm{CO}_{2}$, which origin coke formation, during SEGSR (eq. (8, 10, and 11)). On the other hand, by analyzing Fig. 9 [41] it can be observed, for SEGSR, that at 1 atm coke is completely absent at temperatures above $500 \mathrm{~K}$ and WGFRs higher than 1.8. 
By increasing the pressure from 1 to 50 bar, the formation of a second carbon formed region occurs. This might be because of the enhancement of the reactions in eq. $(8,10$, and 11). In this case coke formation is only completely avoided at WGFRs above 3 (again for temperatures above $500 \mathrm{~K}$ ). In another work, Silva et al. [43] concluded that even using a WGFR as low as 1.5 , it would be possible to work at temperatures below $885 \mathrm{~K}$ (1 atm) without any carbon formation. Furthermore, in order to eliminate the possibility of carbon formation in all the temperature range (500-1400 K) under atmospheric pressure, WGFRs higher than 2 would have to be used. This value is very similar to the one reported by Wang et al. [41] - Fig. 9.

\subsection{GSR with $\mathrm{H}_{2}$ Removal}

The removal of hydrogen from the reaction medium instead of $\mathrm{CO}_{2}$ is another possibility that has been target of some interest. Analogously to the SEGSR, the selective removal of $\mathrm{H}_{2}$ during GSR by means of a membrane reactor (MR) also shifts the thermodynamic equilibrium towards higher $\mathrm{H}_{2}$ yields. Moreover a highly pure $\mathrm{H}_{2}$ stream, which is suitable to be used in polymer electrolyte membrane fuel cells (PEMFCs), is generated. There have been several studies that have focused on the experimental assessment of GSR in MRs, however the study of the thermodynamic behavior of the process has seldom been done. A revision of such work is briefly reported in this section.

Wang et al. [45] investigated the effect of temperature, WGFR, pressure and fraction of hydrogen removal on a MR. Regarding the operation pressure, it was found that higher pressures benefit the permeation of hydrogen through the membrane due to the increase of the driving force. However, the thermodynamics of GSR is not favored by high pressures as already discussed. The authors observed that superior hydrogen production occurs at $1 \mathrm{~atm}$ and, for that reason, all the analysis was performed at this pressure. Fig. 10 [45] depicts the influence of both temperature and WGFR on the production of $\mathrm{H}_{2}$ through GSR in a MR. It is observable that, as expected, the increase of both temperature and WGFR provoke an enhancement in the production of hydrogen. However, $\mathrm{H}_{2}$ production reaches a maximum at a certain temperature and then starts decreasing for higher temperatures (such effect is not verified for $\mathrm{H}_{2}$ removals of $99 \%$ and $100 \%$ ). Regarding the fraction of $\mathrm{H}_{2}$ removal, removing more hydrogen shifts the thermodynamic equilibrium towards higher hydrogen production according to the Le Chatelier's principle. Moreover, higher $\mathrm{H}_{2}$ removal dislocates the maximum hydrogen production to lower 
temperatures (Fig. 10a). While with no $\mathrm{H}_{2}$ removal the maximum $\mathrm{H}_{2}$ yield is approximately 6 at $925 \mathrm{~K}$, the maximum yield becomes close to 7 at $825 \mathrm{~K}$ for $80 \%$ of $\mathrm{H}_{2}$ removal, and with fractional hydrogen removal of 0.99 and 1 , the $\mathrm{H}_{2}$ yield is close to 7 for all range of temperatures considered. The same is verified for all range of WGFRs considered (Fig.10b). Furthermore, the increase in $\mathrm{H}_{2}$ production when the WGFR increases from 9 to 12 is very small. Consequently, the optimum conditions for GSR in the MR were found to be $825-875 \mathrm{~K}$, WGFR of 9 and $1 \mathrm{~atm}$. The formation of both $\mathrm{CO}$ and $\mathrm{CH}_{4}$ is decreased by selectively removing $\mathrm{H}_{2}$.

The formation of carbon was also analyzed by Wang et al. [45]. As can be seen in Fig. 11 [45], a WGFR value of 4.5 is enough to completely inhibit carbon formation for all range of temperatures and fractions of hydrogen removal tested. With exception to the case of fractional $\mathrm{H}_{2}$ removal of 0.99 , the minimum WGFR required to avoid carbon formation decreases slightly with the increase of temperature up to $800 \mathrm{~K}$. From that point on, the decrease with temperature is much faster and from approximately $873 \mathrm{~K}$ on, the influence of the $\mathrm{H}_{2}$ removal fraction on the minimum WGFR is practically negligible. For a fraction of hydrogen removal of 0.99 the minimum WGFR required to inhibit carbon formation decreases very rapidly. By comparing the different levels of hydrogen removal, it can be observed that higher hydrogen removal leads to higher minimum WGFRs necessary to inhibit carbon formation, except for $99 \%$ hydrogen removal (where the minimum WGFR necessary to avoid carbon formation becomes lower than that for lower hydrogen removal fractions at temperatures lower than $923 \mathrm{~K}$ ). In any case, if the optimum WGFR of 9 is used, no problems with carbon formation will exist. 


\section{GSR catalysts developments}

In the last decade extensive research has been done regarding the heterogeneous catalysis of the GSR reaction for either synthesis gas or $\mathrm{H}_{2}$ production. The most investigated materials until now have been $\mathrm{Ni}, \mathrm{Pt}, \mathrm{Co}$ and Ru-based catalysts. Other less researched materials like Rh, Ir and Pd have also shown interesting attributes. Among the above mentioned catalysts, Ni-based catalysts, as non-noble metal-based catalysts, have been extensively studied. At the moment, the main goal is to design highly reducible and with high oxygen mobility redox catalysts for low-temperature GSR [46].

\subsection{Ni-based Catalysts}

Nickel catalysts for the GSR have been extensively studied over the last years. A big advantage that Ni catalysts present when compared to the noble metal-based ones is their lower price.

\subsubsection{Effect of the support on the catalytic performance}

It has been found that the use of different supports in $\mathrm{Ni}$-based catalysts results in much different catalytic performances [47-51]. Table 1 summarizes the catalytic performance and operating conditions of different Ni-based catalysts on GSR. Adhikari et al. [48] compared the performance of $\mathrm{Ni}$ catalysts on different supports: $\mathrm{MgO}, \mathrm{CeO}_{2}$ and $\mathrm{TiO}_{2}$. At $600{ }^{\circ} \mathrm{C}$ and WGFR of 9, it was observed the following order of $\mathrm{H}_{2}$ selectivity: $\mathrm{CeO}_{2}$ $(70 \%)>\operatorname{MgO}(40 \%)>\mathrm{TiO}_{2}(15 \%)$. Moreover, the ceria supported catalyst was found to present the lowest carbon deposition. It was suggested that ceria establishes a better interaction with the nickel active phase, which leads to a higher metal dispersion and inherently available surface area. Pant et al. [50] observed that the presence of ceria affects the reduction of $\mathrm{Ni}^{2+}$ species, thus enhancing the catalyst activity. It has also been suggested that the dual oxidation state $(+4 /+3)$ that ceria presents leads to oxygen release which reacts with the carbon that is deposited, thus reducing coke formation [15, 52-55]. Moreover, $\mathrm{Ni} / \mathrm{CeO}_{2}$ catalyst is able to enhance both methane reforming and WGS reaction and presents high hydrogen selectivity through GSR [28, 56-58]. Also, it has been reported that the $\mathrm{H}_{2}$ yield is highly dependent on the nature of the active phase as well as its interaction with ceria $[28,56,57,59]$. 
The acidic character of $\mathrm{TiO}_{2}$ is responsible for the higher coke formation on $\mathrm{Ni} / \mathrm{TiO}_{2}$, which leads to a worse GSR performance [48]. Nichele et al. [51] showed that $\mathrm{Ni} / \mathrm{TiO}_{2}$ has very low activity in $\mathrm{C}-\mathrm{C}$ bond rupture, even at high temperatures, and that the contribution of the WGS reaction is even smaller. This is due to the fact that anatase, where nickel ions are incorporated after being oxidized and then reduced under $\mathrm{H}_{2}$ flow, is stable only at relatively low temperatures and its weak interaction with $\mathrm{Ni}$ is not able to avoid re-oxidation of the metallic active phase in the steam reforming conditions [51].

Sánchez et al. [49], Pant et al. [50] and Adhikari et al. [56] analyzed the performance of $\mathrm{Ni} / \mathrm{Al}_{2} \mathrm{O}_{3}$ catalysts for the GSR. The first group observed catalyst deactivation after $8 \mathrm{~h}$ time on stream (at 600 and $650^{\circ} \mathrm{C}$ ). Wen et al. [61] verified that $\mathrm{Ni}$ $\mathrm{Al}_{2} \mathrm{O}_{3}$ supported catalysts undergo quick deactivation. However, as already stated, deactivation is highly dependent on, among another things, the support nature. Many authors have verified the formation of carbonaceous deposits over $\mathrm{Ni} / \mathrm{Al}_{2} \mathrm{O}_{3}$, which led to relatively fast catalyst deactivation [49, 50, 61, 62]. Normally, the formation of coke deposits is associated to dehydration, cracking and polymerization reactions which take place on the acid sites of alumina [63]. Besides presenting higher carbon deposition, Pant et al. [50] also concluded that the prepared $\mathrm{Ni} / \mathrm{Al}_{2} \mathrm{O}_{3}$ catalyst presented higher catalyst sintering than the $\mathrm{Ni}$-ceria supported one. It has been suggested that the sintering of the $\mathrm{Ni}$ active phase is associated to a transition of alumina to crystalline phase during reaction [64].

Nichele et al. [51] also tested a $\mathrm{Ni} / \mathrm{ZrO}_{2}$ catalyst, having concluded that it presented high surface area, high stability at $650{ }^{\circ} \mathrm{C}$ and strong interaction of the support with the metal phase. Also, it was found that for lower temperatures $\left(500^{\circ} \mathrm{C}\right)$ the zirconia supported catalyst was even more active. However, there was a lower stability. In the same work a Ni/SBA-15 was also used, having presented insufficient hydrothermal resistance, which led to catalyst deactivation. However, sintering was avoided since it provided a good stabilization of the $\mathrm{Ni}$ active phase.

Nickel supported on neutral $\mathrm{SiC}$ has been reported to present outstanding stability and high yield of syngas [60]. The neutral nature of this material promotes an intrinsic nickel contribution to GSR, especially in terms of dehydrogenation and decarbonylation. Simultaneously, SiC leads to minimal side reactions from the condensation and the dehydration induced by the basic and acid properties, respectively. Because of this, the $\mathrm{Ni} / \mathrm{SiC}$ catalyst is able to present high stability for GSR and low carbon deposition. 
It is, therefore, evident that the nature of the support affects mainly the stability of the active phase. In order to reach a highly stable active phase, strong interactions between the metal phase and the support are required. These strong interactions also lead to higher activity and selectivity.

\subsubsection{Effect of the addition of a promoter on the catalytic performance}

In many studies reported in the literature, promoters have been used in $\mathrm{Ni}$ supported catalysts in order to improve their performance towards the GSR reaction. Table 2 presents, in summary, the effect of the promoter on the catalytic activity.

As previously mentioned, ceria presents good characteristics for GSR, having for that reason been used by many authors as a promoter [53, 67-69]. In general the addition of $\mathrm{CeO}_{2}$ promoter enhances the activity of the non-promoted catalyst. This is mainly related to the capacity of ceria to stabilize the nickel active phase and to promote the steam reforming of the oxygenated hydrocarbons intermediates, thus leading to a reduction of coke deposition. It has also been suggested that Ce inhibits secondary dehydration reactions, which are normally favored by the presence of support acid sites, which lead to the formation of hydrocarbons that are coke precursors and generate fast catalyst deactivation [68]. It is, nonetheless, important to notice that the ceria loading must not be too high. Iriondo et al. [53] suggest that for a $20 \mathrm{wt}$ \% ceria promoter content on alumina, ceria tends to interact with alumina instead of $\mathrm{Ni}$, thus decreasing the stabilization of the nickel active phase and lowering the available surface for $\mathrm{Ni}$ dispersion. In the same way, it is also possible that the bigger size of ceria crystallites could also diminish the interaction between ceria and nickel active phase [70]. On the other hand, Cui et al. [54] showed that the activity of the $\mathrm{La}_{0.3} \mathrm{Ce}_{0.7} \mathrm{NiO}_{3}$ mixed oxide catalyst for GSR is enhanced compared to $\mathrm{LaNiO}_{3}$ catalysts and that its performance is comparable to that of a noble metal like Pt [54].

The use of $\mathrm{ZrO}_{2}$ as a catalyst modifier has also been reported as an alternative promoter $[18,65,67,68]$, despite the fact that $\mathrm{ZrO}_{2}$ alone is not very active for steam reforming [71]. Iriondo et al.[67] observed that the addition of zirconia promoter to alumina not only enhanced the performance of the non-promoted catalyst but also presented better GSR performance than the ceria-promoted catalyst. The addition of an intermediate $\mathrm{ZrO}_{2}$ content $[65,72,73]$ enhanced the $\mathrm{H}_{2}$ yield and the capacity of the catalyst to reform intermediate products (thus suppressing secondary reactions), even at 
$500{ }^{\circ} \mathrm{C}$, due to the enhancement of $\mathrm{H}_{2} \mathrm{O}$ activation by $\mathrm{ZrO}_{2}$. It is suggested that this improvement is associated to the formation of $\mathrm{ZrO}_{2}-\mathrm{Al}_{2} \mathrm{O}_{3}$ species, which facilitates the reduction of $\mathrm{Ni}^{2+}$ [65]. Pant and co-workers [18] came to similar conclusions after performing GSR over a $\mathrm{ZrO}_{2}$-promoted $\mathrm{Ni} / \mathrm{CeO}_{2}$ catalyst. Zirconia is able to make the ceria support more crystalline, consequently improving the metal dispersion. It is also known that, in general, $\mathrm{ZrO}_{2}$ inhibits sintering of metallic active sites in the presence of water at high temperatures [64].

With the aim of reducing the acidity of alumina supports, thus preventing metal sintering and catalyst deactivation, alumina supports have been modified with basic $\mathrm{La}_{2} \mathrm{O}_{3}$ $[22,66,67,74,75]$. It has also been reported the performance of a $\mathrm{Ni} / \mathrm{SiO}_{2}$ modified with $\mathrm{La}_{2} \mathrm{O}_{3}$ for the GSR [76]. The combination of $\mathrm{SiO}_{2}$, which is known to present large surface area and weak acidity, and $\mathrm{La}_{2} \mathrm{O}_{3}$, favored the formation of $\mathrm{H}_{2}$ and $\mathrm{CO}_{2}$ and reduced carbon formation. This decrease in the carbon formation with increasing $\mathrm{La}_{2} \mathrm{O}_{3}$ content was due to the formation of a La carbonate that removes C species deposited on the nickel sites. Therefore, the $30 \mathrm{wt} . \%$ (highest $\mathrm{La}_{2} \mathrm{O}_{3}$ content used) $\mathrm{La}_{2} \mathrm{O}_{3}$ catalyst presented itself as promising system for GSR, since it was stable (Fig. 12) [76], while presenting good glycerol conversion, good $\mathrm{H}_{2}$ yield and low carbon formation.

The addition of basic $\mathrm{Mg}(\mathrm{II})$ to $\mathrm{Ni} / \mathrm{Al}_{2} \mathrm{O}_{3}$ catalysts has been reported to prevent carbon formation by favoring both the adsorption of $\mathrm{H}_{2} \mathrm{O}, \mathrm{O}_{2}, \mathrm{CO}_{2}$ or $-\mathrm{OH}$ fragments and the spillover of such fragments from the support to the metal particles $[20,77,78]$, thus facilitating carbon gasification. Moreover, the use $\mathrm{Mg}(\mathrm{II})$ promoter in $\mathrm{Ni} / \mathrm{Al}_{2} \mathrm{O}_{3}$ materials enhances the stability of $\mathrm{Ni}$ against sintering, since it decreases the degree of interaction of $\mathrm{Ni}$ with alumina through intercalation between the nickel active phase and alumina. Consequently, the incorporation of nickel in the alumina phase is inhibited [67]. It has been found that the use of low amounts of $M g(\mathrm{II})$ promoter leads to higher metal dispersion, thus favoring glycerol conversion into gaseous products, while higher loadings result in lower coke deposition [20]. Other basic promoters such as Mo [66, 79-83] and Ca $[66,69,79]$ have also been reported to enhance the GSR performance of non-promoted catalyst, for the same reasons previously mentioned for basic modifiers. Huang et al. [66] observed that the simultaneous presence of Mo-La-Ca inhibits the interaction between nickel and the commercial Ca-containing Linde-type 5A zeolite support, thus resulting in a remarkable stability during GSR (no deactivation during $100 \mathrm{~h}$ time-on-stream). Gong and co-workers [84] verified that the synergetic effect caused by the partial substitution 
of La by $\mathrm{Ca}$ in the perovskite structure leads to enhanced metal dispersion and stronger metal-support interaction.

Hakim et al. [85] studied the GSR reaction over hydroxyapatite-supported Ni-Ce$\mathrm{Cu}$ catalysts. It was found that doping with $\mathrm{Cu}$ influenced the catalytic performance of the catalyst. Also, higher $\mathrm{Cu}$ contents led to higher glycerol conversions and hydrogen production. Hakim's group came to the conclusion that the interaction between $\mathrm{CuO}$ and $\mathrm{CeO}_{2}$ on the hydroxyapatite support in the GSR reaction enhanced the active sites (more active sites) of the catalysts. Moreover, the presence of ceria facilitated the reduction and increased the dispersion of the copper species on the surface of the catalysts. In terms of $\mathrm{Ni}$ content, it was found that it does not enhance significantly the production of $\mathrm{H}_{2}$. As a matter of fact, it is suggested that since for the catalysts with higher Ni loading there is a greater presence of $\mathrm{NiO}$ phase on the surface of the catalysts during preparation and calcination, not all the nickel ions substituted the position of $\mathrm{Ca}^{2+}$ in the hydroxyapatite support and some metallic nickel became agglomerated.

Profeti et al. [86] studied the catalytic activity of $\mathrm{Ni} / \mathrm{CeO}_{2}-\mathrm{Al}_{2} \mathrm{O}_{3}$ catalysts modified with noble metals (Pt, Ir, Pd and $\mathrm{Ru}$ ) for the GSR reaction. The addition of noble metals stabilizes the $\mathrm{Ni}$ sites in the reduced state, increasing the glycerol conversion and decreasing the coke formation. Moreover, this stabilization of the nickel surface species interacting with the support occurs at lower temperatures in the presence of small amounts of noble metals due to hydrogen spillover effect. A more detailed review on noble metal-based catalysts for GSR is done in further sections.

\subsection{Pt-based Catalysts}

Noble metal catalysts normally are more active and stable towards the GSR reaction that Ni-based materials [87]. Pt-based catalysts are no exception and because of that, many authors have studied the potential of these catalysts for $\mathrm{H}_{2}$ production through this process.

\subsubsection{Effect of the support on the catalytic performance}

Platinum catalysts supported on carbon have been investigated for the GSR either for syngas or hydrogen production [88-90]. A summary of the catalytic performance and 
operating conditions of some Pt-based catalysts is presented in Table 3. It has been found that Pt/C supported catalysts present higher stability during GSR than other Pt-based materials making use of different supports $\left(\mathrm{Al}_{2} \mathrm{O}_{3}, \mathrm{ZrO}_{2}, \mathrm{MgO} / \mathrm{ZrO}_{2}\right.$, and $\left.\mathrm{CeO}_{2} / \mathrm{ZrO}_{2}\right)$; this is due to the very low formation of $\mathrm{C}_{2}$-hydrocarbons, which is symptomatic of lower carbon formation on the Pt/C catalyst [88]. Sutar et al. [89] attained catalytic results for GSR over a $\mathrm{Pt} / \mathrm{C}$ sample that are in general comparable to the ones presented in the previous section for some $\mathrm{Ni}$-based catalysts. However, for nickel catalysts those results were obtained at temperatures around $600-700^{\circ} \mathrm{C}$, while in this case the temperature used was $400{ }^{\circ} \mathrm{C}$ - Table 3. Simonetti et al. [88] reported an even more noticeable superior activity of Pt-based catalysts for the GSR compared to nickel ones.

Although Pt/C supported catalysts present very interesting results at relatively low temperatures, they are more suitable for syngas production. Oxide supports, on the other hand, promote the WGS reaction, thus being more appropriated for hydrogen production with lower $\mathrm{CO}$ content [88, 93-96]. Despite this, acid $\mathrm{ZrO}_{2}$ and $\mathrm{Al}_{2} \mathrm{O}_{3}$ supports lead to fast deactivation of platinum catalysts mainly due to coke deposition, which results from the promotion of lateral reactions of dehydration, hydrogenolysis, dehydrogenation and condensation [88, 97], as seen for $\mathrm{Ni}$-based catalysts. It has been reported that the acidity of supports decreases in the order $\mathrm{Al}_{2} \mathrm{O}_{3}>\mathrm{ZrO}_{2}>\mathrm{SiO}_{2}[97,98]$. Therefore, a solution for this deactivation problem includes the use of a support with lower acidity, like $\mathrm{SiO}_{2}[91$, 97, 99]. According to Pompeo et al. [91, 97], the silica support allows the Pt catalysts to promote mainly dehydrogenation reactions and subsequent cleavage of $\mathrm{C}-\mathrm{C}$ bonds, thus presenting excellent activity to gaseous products, high $\mathrm{H}_{2}$ selectivity and remarkable stability over time. It was also observed for $\mathrm{Pt} / \mathrm{SiO}_{2}$ supported catalyst that increasing the Pt content maintains the same active phase (same metal dispersion and average particle size). Therefore, the 2 wt.\% Pt catalyst shown in Table 3 presented better performance than the $1 \mathrm{wt} . \%$ Pt one. Moreover, a comparison between Pt and Ni catalysts supported on $\mathrm{SiO}_{2}$ was done at 350 and $450{ }^{\circ} \mathrm{C}$. At these temperatures the $\mathrm{Ni}$-based catalysts ended up deactivating after a couple of hours, while the Pt-based catalysts presented higher stability; moreover, at $350{ }^{\circ} \mathrm{C}$ the $2 \mathrm{wt} . \%$ Pt catalyst was considerably more stable than the 1 wt.\% Pt catalyst (Fig. 13) [91].

A Pt $/ \mathrm{Y}_{2} \mathrm{O}_{3}$ catalyst was tested for GSR by Cui et al. [54], having presented high glycerol conversion into gaseous products as well as high hydrogen yield. 


\subsubsection{Effect of the addition of a promoter on the catalytic performance}

Similarly to Ni-based catalysts, the performance of Pt-based catalysts can be enhanced by adding promoters. Table 4 summarizes the effect of different promoters on the GSR catalytic activity of Pt-based catalysts. It has been demonstrated that the heat of $\mathrm{CO}$ adsorption on Pt-based catalysts can be decreased by the formation of metal alloys [100, 101]. Simonetti et al. [90] came to the conclusion that bimetallic Pt-Re/C catalysts with atomic $\mathrm{Pt} / \mathrm{Re}$ ratios $\leq 1$ are 5 times more active to syngas production through GSR than monometallic Pt/C and Pt-Re with a higher Pt/Re ratio (10). The authors suggest that the primary promotional effect of Re is to weaken the interaction between $\mathrm{CO}$ and the surface, thus leading to faster turnover of catalytic sites. Kunkes et al. [93] added Fe; Cu; Sn; Ir; Co; Ni; Rh; Os; Ru; or Re to Pt supported on C. The addition of Fe; Cu; Sn; Ir; Co; $\mathrm{Ni}$; or Rh had a detrimental or neutral effect on the catalytic activity for all reaction temperatures $\left(275-350^{\circ} \mathrm{C}\right)$. According to Pompeo et al. [91], the fact that the coexistence of $\mathrm{Pt}$ and $\mathrm{Ni}$ did not improve the catalytic performance suggests that the formation of a bimetallic Pt-Ni phase affects the platinum electronic properties. On the other hand, the addition of Os; Ru; or Re to Pt enhanced the syngas production comparatively to $\mathrm{Pt} / \mathrm{C}$, being that Re was the promoter that allowed the best syngas production improvement.

The addition of ceria promoter has been verified as advantageous, but in this case for platinum-based catalysts [88, 92, 97]. As already mentioned, the addition of ceria to a support like alumina reduces its acidity, thereby improving the catalyst stability and $\mathrm{H}_{2}$ selectivity and reducing the formation of undesirable products and coke deposition. Montini et al. [92] verified that the $\mathrm{Pt} / \mathrm{CeO}_{2} / \mathrm{Al}_{2} \mathrm{O}_{3}$ catalyst, despite presenting improved performance, still deactivated after $20 \mathrm{~h}$ time-on stream (Fig. 14) [92]. This deactivation could be due to coke deposition on the active sites and only marginally due to Pt sintering. Similar behavior, in terms of performance enhancement, has been observed for Pt-based catalysts promoted with basic oxides like $\mathrm{La}_{2} \mathrm{O}_{3}$ [92] and $\mathrm{MgO}$ [88]. However, the $\mathrm{La}_{2} \mathrm{O}_{3}$ promoted catalyst only deactivated after $50 \mathrm{~h}$ time-on-stream, as can be seen in Fig. 14.

On the other hand, Pompeo et al. [97] reported the attainment, for a Pt/Ce $\mathrm{Zr}_{1} \alpha$ catalyst, of higher $\mathrm{H}_{2}$ selectivity and glycerol conversion to gaseous products than both $\mathrm{Pt} / \mathrm{Y}-\mathrm{Al}_{2} \mathrm{O}_{3}$ and $\mathrm{Pt} / \mathrm{ZrO}_{2}$ catalyst. The promoted catalyst presented higher average platinum particle size than the other two catalysts. Claus and co-authors [102] suggested that larger particles present a higher number of face atoms of the metal crystallite. Moreover, the adsorption of oxygenated hydrocarbons for posterior C-C cleavage can be 
preferably performed at face positions, thus leading to higher hydrogen selectivity. Furthermore, the simultaneous presence of $\mathrm{Ce}$ and $\mathrm{Zr}$ promotes the WGS reaction, thus enhancing the $\mathrm{H}_{2}$ selectivity [93].

\subsection{Co-based Catalysts}

Cobalt catalysts have shown good performance in ethanol reforming for hydrogen production and are proposed as appropriate catalytic systems [103-105]. However they have shown significant deactivation through sintering and surface cobalt deactivation. Even so, many authors have investigated in the last years the catalytic behavior of Cobased materials for GSR [23, 106-109].

\subsubsection{Effect of the support on the catalytic performance}

The use of alumina as support for Co active phase has been reported [107], having been observed the existence of both strong and weak acid sites on the catalyst surface with an acidic/basic ratio of approximately 5.5. Therefore, expected carbon deposition was verified. Moreover, TPO-TPR and TPR-TPO cycles showed different reactivity of the carbon deposited on the surface of the coked catalyst, meaning that there were at least two types of carbon pools on the surface. One of the pools was reactive in the presence of $\mathrm{H}_{2}$ while the other was inert to $\mathrm{H}_{2}$, reacting only in the presence of $\mathrm{O}_{2}$.

Zhang et al. [106] verified that $\mathrm{Co} / \mathrm{CeO}_{2}$ catalyst for GSR originated small concentrations of $\mathrm{CH}_{4}$ and $\mathrm{CO}$ at the reactor outlet stream. Furthermore, only slight changes on their concentrations were observed while increasing the reaction temperature, meaning that the $\mathrm{Co} / \mathrm{CeO}_{2}$ catalyst did not catalyze effectively both WGS and steam reforming of methane. Dehydration of glycerol was not observed over the ceria-supported catalyst, and so no significant deactivation occurred.

A comparison of the catalytic performance of both types of catalysts described along this section for GSR is presented in Table 5.

\subsubsection{Effect of the addition of a promoter on the catalytic performance}

It has been found that bimetallic $\mathrm{Co}-\mathrm{Ni} / \mathrm{Al}_{2} \mathrm{O}_{3}$ catalyst, used by Adesina et al. [108], presents an enhanced activity for steam reforming of methane and propane due to the 
synergism between the $\mathrm{Ni}$ and Co metals [110]. The reasons of such synergism are not, however, disclosed. The coexistence of both Lewis and Bronsted acid sites was discovered through physicochemical characterization. However, the bimetallic catalyst presents a net surface acidity (acidic/basic ratio of 9). Analogously to what was reported elsewhere [107], it was verified the occurrence of carbon deposition during reaction, which led to a reduction of the surface area and pore volume of the catalyst. Furthermore two types of carbon deposits were observed once again, being that one of them is inert to $\mathrm{H}_{2}$ as well. The GSR catalytic activity of this promoted catalyst is compared in Table 5 with that for the non-promoted catalysts presented in the previous section.

CeZr mixed oxides have also been target of attention since they allow the insertion of transition metals, like $\mathrm{Co}$ and $\mathrm{Ni}$, and/or noble metals, like $\mathrm{Ru}$ and $\mathrm{Rh}$, into the oxide structure, thus increasing the active phase-support interaction [111-113]. Araque et al. [23] evaluated the effect of the active phase by using two mixed oxide catalysts: $\mathrm{Ce}_{2} \mathrm{Zr}_{1.5} \mathrm{Co}_{0.5} \mathrm{O}_{8-\delta}$ and $\mathrm{Ce}_{2} \mathrm{Zr}_{1.5} \mathrm{Co}_{0.47} \mathrm{Rh}_{0.07} \mathrm{O}_{8-\delta}$. Rhodium did not significantly affect the glycerol total conversion. However, it highly affected the conversion of glycerol into gaseous products at the expense of liquid ones. It was also observed an enhancement of the $24 \mathrm{~h}$ average $\mathrm{H}_{2}$ production from $1.6 \mathrm{molH}_{2} \cdot \mathrm{mol}_{\mathrm{Gly}}{ }^{-1}{ }^{-1}$ up to $5.8 \mathrm{molH}_{2} \cdot \mathrm{mol}_{\mathrm{Gly} \text {.in }}{ }^{-1}$ when $\mathrm{Rh}$ was added to the mixed oxide catalyst. Also, for the Rh-containing catalyst, an average production of $\mathrm{H}_{2}$ of $6.7 \mathrm{molH}_{2} \cdot \mathrm{mol}_{\mathrm{Gly} \text {.in }}{ }^{-1}$ was obtained for over $16 \mathrm{~h}$, while the other catalyst kept stable only for $1 \mathrm{~h}$. The enhanced behavior of the Rh containing catalyst is related to the capacity of Rh to break the $\mathrm{C}-\mathrm{C}$ bonds. The loss of activity verified is due to the loss of the $\mathrm{C}-\mathrm{C}$ bond breaking capacity, since $\mathrm{C}_{2} \mathrm{H}_{4}$ formation was observed when deactivation occurred. In another work, Roger and co-authors [109] studied the effect of the $\mathrm{Ce} / \mathrm{Zr}$ ratio in fluorite-type mixed oxides of CeZr-CoRh catalysts on the $\mathrm{H}_{2}$ production by GSR. Catalysts with three different $\mathrm{Ce} / \mathrm{Zr}$ ratios were prepared: $\mathrm{Ce}_{0.53} \mathrm{Zr}_{2.97} \mathrm{Co}_{0.47} \mathrm{Rh}_{0.03} \mathrm{O}_{8-\delta}$ with poor ceria content $\left(\mathrm{CZ}^{\mathrm{P} C o R h}\right), \mathrm{Ce}_{2} \mathrm{Zr}_{1.5} \mathrm{Co}_{0.47} \mathrm{Rh}_{0.03} \mathrm{O}_{8-\delta}$ with intermediate ceria content ( $\left.C Z^{\prime} \mathrm{CoRh}\right)$, and $\mathrm{Ce}_{2.59} \mathrm{Zr}_{0.91} \mathrm{CO}_{0.47} \mathrm{Rh}_{0.03} \mathrm{O}_{8-\delta}$ rich in ceria $\left(\mathrm{CZ}^{\mathrm{R}} \mathrm{CoRh}\right)$. It was observed that the increase of the Ce content enhances both the stability (Fig. 15) [109] and selectivity towards $\mathrm{H}_{2}$ and $\mathrm{CO}_{2}$. This happens because of the improved cobalt reducibility and reoxidation properties, oxygen storage capacity and metal support interaction. Also, the catalytic stability and activity of the catalysts is related to their capacity to activate $\mathrm{H}_{2} \mathrm{O}$ under reaction conditions, thus favoring the steam reforming reaction over the decomposition reaction. By increasing the Ce content, the $\mathrm{H}_{2} \mathrm{O}$ activation is favored for a 
longer period of time, thus allowing carbon gasification and delaying the catalyst deactivation; even so this effect is not very pronounced (Fig. 15).

\subsection{Ru-based catalysts}

Ruthenium is currently, along with nickel and platinum, one of the most promising materials to catalyze hydrogen production through GSR. Moreover, $\mathrm{Ru}$ is the least expensive among all noble metals [114]. Ru-based catalysts have been reported has having superior catalytic activity for $\mathrm{H}_{2}$ production, not only through GSR but also through methane steam reforming, for example [1, 115, 116]. By comparing the GSR activity of catalysts loaded with Group 8-10 metals supported on oxides $\left(\mathrm{Y}_{2} \mathrm{O}_{3}, \mathrm{ZrO}, \mathrm{CeO}_{2}, \mathrm{La}_{2} \mathrm{O}_{3}\right.$, $\left.\mathrm{SiO}_{2}, \mathrm{MgO}, \mathrm{Al}_{2} \mathrm{O}_{3}\right)$, the order $\mathrm{Ru} \approx \mathrm{Rh}>\mathrm{Ni}>\mathrm{Ir}>\mathrm{Co}>\mathrm{Pt}>\mathrm{Pd}>\mathrm{Fe}$ was found in $\mathrm{La}_{2} \mathrm{O}_{3^{-}}$ supported materials [117]. It has also been reported that the order of the catalytic activity of Group 8-10 metal catalysts over $\mathrm{SiO}_{2}$ is as follows: $\mathrm{Ru} \approx \mathrm{Rh}>\mathrm{Ni}>\mathrm{Ir}>\mathrm{Pt} \approx \mathrm{Pd} \gg \mathrm{Co} \approx$ Fe [117].

\subsubsection{Effect of the support on the catalytic performance}

Hirai et al. [117] prepared several catalysts loaded with Group 8-10 metals supported on $\mathrm{Y}_{2} \mathrm{O}_{3}, \mathrm{ZrO}_{2}, \mathrm{CeO}_{2}, \mathrm{La}_{2} \mathrm{O}_{3}, \mathrm{SiO}_{2}, \mathrm{MgO}$, and $\mathrm{Al}_{2} \mathrm{O}_{3}$ via a conventional impregnation method. Among all the metals used, Ru was the one that showed the best catalytic activity. Therefore, since ruthenium allowed the attainment of the highest $\mathrm{H}_{2}$ yield, the effects of the previously mentioned supports for ruthenium on GSR were evaluated at 600 ${ }^{\circ} \mathrm{C}$. The Ru/MgO supported catalyst showed very low glycerol conversion to gaseous products compared to the other samples. This low activity is due to the fact that ruthenium on $\mathrm{MgO}$ is hard to be reduced to metallic ruthenium and so the number of active sites would decrease [118]. The $\mathrm{Ru} / \mathrm{Al}_{2} \mathrm{O}_{3}$ supported catalyst presented the lowest glycerol conversion into gaseous products. It also showed low $\mathrm{H}_{2}$ yield because of the higher selectivity towards methane production and lower selectivity to $\mathrm{CO}_{2}$. On the other hand, both $\mathrm{Ru} / \mathrm{Y}_{2} \mathrm{O}_{3}$ and $\mathrm{Ru} / \mathrm{ZrO}_{2}$ supported catalysts presented high glycerol conversion into gaseous products and $\mathrm{H}_{2}$ yield. In fact, the $\mathrm{Ru} / \mathrm{Y}_{2} \mathrm{O}_{3}$ sample was the one that presented the best results. This has been attributed to the ability of yttria to promote de WGS reaction [119]. Considering this, an optimization of the loading level of ruthenium was performed at $500{ }^{\circ} \mathrm{C}$, to compare the catalytic activity at lower conversions [117]. The $\mathrm{H}_{2}$ 
yield kept increasing as the ruthenium loading increased up to $3 \mathrm{wt} . \%$. A further increase in the ruthenium loading to $5 \mathrm{wt}$.\% did not affect the $\mathrm{H}_{2}$ yield and so, the optimal loading was found to be $3 \mathrm{wt}$.\%. Finally, it was observed that both glycerol conversion into gaseous products and $\mathrm{H}_{2}$ yield did not decrease during a $24 \mathrm{~h}$ time-on-stream test, as shown in Fig. 16 [117]. Very small carbon deposition was verified after $24 \mathrm{~h}$ reaction, thus meaning that the $3 \mathrm{wt} . \% \mathrm{Ru} / \mathrm{Y}_{2} \mathrm{O}_{3}$ material is apparently resistant for the deactivation caused by carbon deposition. However, some deactivation caused by sintering of the dispersed catalytic metal clusters was observed. Ultimately the authors concluded that the $\mathrm{Ru} / \mathrm{Y}_{2} \mathrm{O}_{3}$ catalyst presents very high performance in GSR. The catalytic performance of some of these Rubased catalysts for GSR is presented in Table 6.

\subsubsection{Effect of the addition of a promoter on the catalytic performance}

Kim and Lee [119] studied the GSR on Ru and Ru-Me ( $\mathrm{Me}=\mathrm{Fe}, \mathrm{Co}, \mathrm{Ni}$, and $\mathrm{Mo}$ ) catalysts supported on $\mathrm{Y}_{2} \mathrm{O}_{3}, \mathrm{Ce}_{0.5} \mathrm{Zr}_{0.5} \mathrm{O}_{2}$, and commercial $\gamma-\mathrm{Al}_{2} \mathrm{O}_{3}$. It was verified that the use of different supports affects the performance of the catalysts, being that for the Rubased catalysts supported on reducible yttria and ceria-zirconia there was a significant enhancement of the $\mathrm{H}_{2}$ production turnover rate and selectivity. This happens because these supports tend to facilitate the WGS reaction. On the other hand, the acidic $\gamma$ alumina supported Ru-based catalysts showed low $\mathrm{H}_{2}$ production turnover rate, high $\mathrm{CO}$ selectivity and formation of $C_{1}-C_{2}$ hydrocarbons for the reasons already stated.

In opposition to what was verified for the different supports, the metallic promoters did not influence much neither $\mathrm{H}_{2}$ production rate nor selectivity. On the other hand, the addition of metallic promoters led to lower catalysts deactivation. In terms of coke deposition, both yttria and ceria-zirconia supports showed superior resistance against coke formation on the catalysts. In fact, very small deposited amounts of carbonaceous species were verified for these supports (<3 wt.\%). However, deactivation of the catalysts at levels between $15 \%$ and $80 \%$ was observed. Since the low amounts of deposited coke could never lead to such deactivation levels, the authors suggest that sintering of the dispersed catalytic metal clusters was the cause of the verified activity drop. As can be seen in Fig. 17 [119], the Ru-Mo/ $\mathrm{Ce}_{0.5} \mathrm{Zr}_{0.5} \mathrm{O}_{2}$ and $\mathrm{Ru}-\mathrm{Mo} / \mathrm{Y}_{2} \mathrm{O}_{3}$ catalysts exhibited superior stability against deactivation by sintering and lower carbon deposition. The results suggest that the $\mathrm{MoO}_{x}$ species effectively diminished sintering of the surface metal clusters. 
Ru-based catalysts supported on $\mathrm{Mg}(\mathrm{Al}) \mathrm{O}$ mixed oxide were reported by Gallo et al. $[120,121]$. The $M g(A l) O$ mixed oxide support plays an important role in enhancing the performance of the catalyst. Ru based catalysts supported on $\mathrm{Mg}(\mathrm{Al}) \mathrm{O}$ mixed oxides have been reported in the literature to present good performance in steam reforming of ethanol [123], acetic acid [124] and hydrocarbons [125-127]. It is known that $\mathrm{Mg}(\mathrm{Al}) \mathrm{O}$ oxides are able to stabilize supported metal nanoparticles, even at high operating temperatures and/or glycerol concentrations, thus avoiding metal nanoparticles sintering [120]. The presence of $\mathrm{Mg}$ in the support is, in part, responsible for this good behavior. The effect of Sn doping on the bimetallic Ru-Sn/Mg(Al)O supported catalysts was accessed as well by using catalysts with different Sn loadings [120]. The Ru-based catalyst without tin showed very high glycerol conversion with high selectivity towards $\mathrm{H}_{2}$ and $\mathrm{CO}_{2}$, and $\mathrm{CO}$ selectivity lower than $10 \%$ during the entire catalytic run. By increasing the tin loading, a progressive increase in both $\mathrm{CO}$ and $\mathrm{CH}_{4}$ selectivity was verified. On the other hand, the $\mathrm{CO}_{2}$ selectivity decreased gradually. Therefore, the catalysts that showed the most attractive results in terms of specific $\mathrm{H}_{2}$ productivity ( $\mathrm{mmol} \mathrm{H} \cdot \mathrm{mmol} \mathrm{Ru}_{\mathrm{exp}}{ }^{-1} \cdot \mathrm{min}^{-1}$ ) and specific activity (mmol

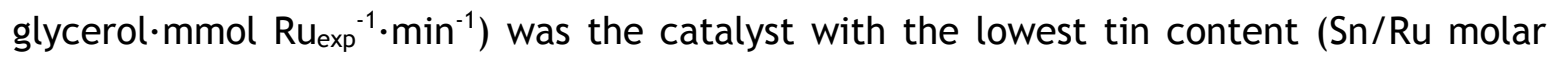
ratio of 0.33 ). It was concluded that the addition of tin has different effects depending on the $\mathrm{Sn} / \mathrm{Ru}$ molar ratios. For low $\mathrm{Sn} / \mathrm{Ru}$ molar ratios it was verified that both activity and $\mathrm{H}_{2}$ productivity per exposed $\mathrm{Ru}$ sites are significantly enhanced, since tin selectively coated Ru faces, and only co-ordinatively unsaturated Ru sites, which are the most active ones, are exposed. However, by increasing the ratio a large amount of acidic tin oxides is unselectively deposited onto support materials. Therefore, glycerol decomposition is promoted rather than GSR, thus leading to high amounts of $\mathrm{CO}$ and finally to coke deposition responsible for the catalyst deactivation [120]. A comparison between the GSR performance of some of the promoted ruthenium catalysts here discussed and the nonpromoted catalysts discussed in the previous section is presented in Table 6.

\subsection{Other noble metal-based Catalysts}

In addition to the materials analyzed in the previous sections, there are others that have not been so frequently reported in the literature for $\mathrm{H}_{2}$ production through GSR, but still present some interesting results. In this section some of those materials are reviewed. 
Zhang et al. [106] studied, has already mentioned, the performance of ceriasupported Ir, Co and Ni catalysts for GSR in the temperature range between $250-600{ }^{\circ} \mathrm{C}$. Among all the catalysts tested, the $\mathrm{Ir} / \mathrm{CeO}_{2}$ sample was the one that presented the best performance. It was verified that the methane concentration greatly decreased with increasing temperature, thus meaning that the steam reforming of methane has occurred in a significant extent. Consequently, most of the produced methane was converted into $\mathrm{H}_{2}$. Also, the increasing concentrations of $\mathrm{CO}_{2}$ in the outlet gas stream and progressively lower $\mathrm{CO}$ content for increasing temperatures, indicates that the $\mathrm{Ir} / \mathrm{CeO}_{2}$ catalyst successfully catalyzes the WGS reaction. Therefore, $\mathrm{Ir} / \mathrm{CeO}_{2}$ seems to be a very promising catalyst for GSR.

Chiodo and co-workers [128] reported the comparison between a $\mathrm{Rh} / \mathrm{Al}_{2} \mathrm{O}_{3}$ catalyst and several Ni supported materials for the GSR. The group came to the conclusion that the rhodium catalyst is more active and stable than the nickel-based ones. However, after approximately $8 \mathrm{~h}$ fast deactivation of the catalyst was verified. Rodhium catalysts are more resistant to coke formation than $\mathrm{Ni}$-based due their high activity in hydrogenation reactions which, in case of removal of unsaturated compounds from the catalyst surface, is fundamental to avoid coke formation. Furthermore, Rh materials are active in $\mathrm{C}=\mathrm{C}$ bond activation. Considering that the main species that reach the catalyst surface are $\mathrm{CO}$ and olefins $\left(\mathrm{C}_{2} \mathrm{H}_{4}, \mathrm{C}_{3} \mathrm{H}_{6}\right)$, it is therefore deducible that the catalytic performance depends on the tendency towards $\mathrm{C}=\mathrm{C}$ cleavage and coke formation inhibition through polymerization of $\mathrm{CH}_{x}$ species and/or CO dissociation (Boudouard reaction) [129-132]. Despite this, there are still some improvements that need to be done regarding the relatively fast deactivation of Rh-based catalysts.

Ebshish et al. [133] compared the catalytic performance of $1 \mathrm{wt} . \% \mathrm{Ce} / \mathrm{Al}_{2} \mathrm{O}_{3}$ and 1 wt.\% Pd/ $\mathrm{Al}_{2} \mathrm{O}_{3}$ catalysts, as well as the performance of $1 \mathrm{wt} . \% \mathrm{Ce} / \mathrm{Al}_{2} \mathrm{O}_{3}$ and $10 \mathrm{wt} . \%$ $\mathrm{Ce} / \mathrm{Al}_{2} \mathrm{O}_{3}$. The authors observed that the $1 \mathrm{wt} . \%$ palladium catalyst supported on alumina presented better glycerol conversion to gaseous products as well as better $\mathrm{H}_{2}$ yield than both 1 wt.\% $\mathrm{Ce} / \mathrm{Al}_{2} \mathrm{O}_{3}$ and 10 wt.\% Ce/ $/ \mathrm{Al}_{2} \mathrm{O}_{3}$ catalysts. In terms of $\mathrm{H}_{2}$ selectivity, the 10 wt.\% $\mathrm{Ce} / \mathrm{Al}_{2} \mathrm{O}_{3}$ sample was superior to the other two catalysts, having low amounts of carbon oxides been formed. This enhancement was suggested to be due to the higher metal loading. However, it also presented higher carbon formation than the other Cebased catalyst. It has been concluded that in general Pd is more active and more stable than Ce because of its favorable lattice parameters. It is also important to remark the 
fact that this was the first time that Ce was reported as having been used as a catalyst for GSR. In all the previous works, only its oxide had been used as catalyst support.

A summary of some of the catalysts reviewed in this section and their catalytic performances in GSR is presented in Table 7. 


\section{Mechanisms and Kinetics}

Establishment of reaction rate equations for any process, and for GSR in particular, is crucial for reactor design, while the comprehension of the associated mechanism may lead to improvements in catalyst design with the inherent implications at industrial scale. In the last years many authors have studied the kinetics of the GSR over different catalysts and have proposed different reaction mechanisms, being that there has not been full agreement on this matter. In this section a review of the proposed reaction kinetics, as well as the most accepted reaction mechanisms is done. This is, as mentioned above, fundamental for reactor modeling, design, optimization and operation.

Normally the reaction rate data for the GSR have been fitted to a general powerlaw type equation with the following form:

$$
-r_{G S R}=k p_{G}^{a} p_{W}^{b}
$$

where $k$ is the reaction rate constant (defined by the Arrhenius equation), $p_{G}$ and $p_{W}$ and $a$ and $b$ are the partial pressures and the reaction orders of glycerol and steam, respectively.

Normally it is difficult to compare activation energies reported in the literature since the conditions used differ from study to study. Moreover, special attention should be put on whether or not mass (and even heat) transfer resistances are absent, so that cases of kinetics falsification can be identified. In Table 8 are presented some literature values of kinetic parameters obtained for some of the most relevant GSR catalysts in the absence of any resistances. In terms of activation energy, a comparison between all the $\mathrm{Ni}$-based and Co-based catalysts presented in Table 8, which were tested at higher temperatures, can however be done. Among these catalysts, it is possible to notice that while the $\mathrm{Ni}$ or $\mathrm{Co} / \mathrm{Al}_{2} \mathrm{O}_{3}$ supported catalysts present activation energies around 60-70 $\mathrm{kJ} / \mathrm{mol}$, both the $24.1 \mathrm{wt} . \% \mathrm{Ni}-26.1 \mathrm{wt} . \% \mathrm{Mg}-49.8 \mathrm{wt} . \%$ Al sample and the $15 \mathrm{wt} . \% \mathrm{Ni}-10$ wt.\% $\mathrm{ZrO}_{2} / \mathrm{CeO}_{2}$ material present activation energies of $38 \mathrm{~kJ} \cdot \mathrm{mol}^{-1}$ and $43 \mathrm{~kJ} \cdot \mathrm{mol}^{-1}$, respectively. This suggests that the reaction mechanism or the rate-determining step for the last two samples may be different from that over the other catalysts. On the other hand, both Ru-based and Pt-based catalysts were tested at lower temperatures, being that the $5 \% \mathrm{Ru} / \mathrm{Al}_{2} \mathrm{O}_{3}$ sample, among all catalysts in Table 8 , is the one that presents the lowest activation energy. Vaidya and co-authors [114] suggest that this might occur due 
to the enhanced catalyst activity even at low reaction temperatures, which is associated to the high loading level of Ru. It should also be noticed the substantial difference between the activation energies of both $\mathrm{Ni} / \mathrm{CeO}_{2}$ catalysts $\left(36.5 \mathrm{vs} .103 .4 \mathrm{~kJ} \cdot \mathrm{mol}^{-1}\right)$. Since for both cases, external and internal mass transfer limitations were minimized by selecting suitable flow rates and an appropriate particle size range, respectively, this peculiar difference may be associated to the different temperature ranges used, possibly different metal loadings, and different preparation methods. The last factor is probably the one that contributes the most to the verified significant difference. In comparison to the wet impregnation technique, the deposition-precipitation method improves, among other things, the metallic dispersion and decreases catalyst sintering.

In terms of glycerol partial reaction order, all Ni-based catalysts presented similar values (0.2-0.5) except for the Ni-Mg-Al sample, which presents a value of 1.0. This difference suggests that different reaction mechanisms or different rate-determining steps may exist for these catalysts. Regarding the Co-based materials, both present low values of glycerol partial reaction order, especially the $\mathrm{Co} / \mathrm{Al}_{2} \mathrm{O}_{3}$ catalyst. As a matter of fact, this catalyst also presents small values of glycerol partial reaction order for the production of $\mathrm{C}_{1}$ products $\left(\mathrm{CO}_{2}, \mathrm{CO}\right.$ and $\left.\mathrm{CH}_{4}\right)$. This might indicate the existence of a cancellation effect of the molecularly adsorbed glycerol in the rate-controlling step and the presence of a glycerol adsorption term in the denominator of the LangmuirHinshelwood rate expression (see eq. (30)) [107]. Therefore, an apparent reduced order for glycerol in the overall reaction rate is obtained. For the Pt- and the Ru-based catalysts, glycerol partial reaction orders of 1 were considered as a valid approach for the low glycerol concentrations used. However, this assumption may not be valid for more concentrated solutions, which can be used during real operation in reformers. In terms of $\mathrm{H}_{2} \mathrm{O}$ reaction order, for most of the catalysts in Table 8 it is considered to be zero due to the use of excess of water. For the others, however, values between 0.3-0.4 were obtained despite the excess steam used.

The formation rates of $\mathrm{H}_{2}, \mathrm{CO}_{2}, \mathrm{CO}$ and $\mathrm{CH}_{4}$ have been often fitted to a power-law expression (eq. (15)) as well [107, 108, 134]. For all cases, the formation rate of CO was inhibited by steam (negative value of $b$ ). This can either be because of the competitive adsorption of steam on the same active sites as the surface precursor for CO production (especially at high steam partial pressures), or because of CO consumption via WGS reaction [134]. For the other gases, positive values of $a$ and $b$ were obtained, meaning 
that both glycerol and steam positively contribute to $\mathrm{H}_{2}, \mathrm{CO}_{2}$ and $\mathrm{CH}_{4}$ formation. In terms of activation energy, $\mathrm{H}_{2}, \mathrm{CO}_{2}$ and $\mathrm{CO}$ formation present similar values (in the range 60-75 $\left.\mathrm{kJ} \cdot \mathrm{mol}^{-1}\right)[108,134]$ while the formation of methane presents a much higher activation energy $\left(100-120 \mathrm{~kJ} \cdot \mathrm{mol}^{-1}\right)[107,108,134]$.

In what concerns the reaction mechanism, Adesina and co-workers [108] came to the conclusion that the most adequate one for the GSR reaction over the $5 \mathrm{wt} . \%$ Co-10 wt.\% $\mathrm{Ni} / \mathrm{Al}_{2} \mathrm{O}_{3}$ catalyst is the Langmuir-Hinshelwood dual site mechanism with molecular adsorption of both glycerol and steam. This mechanism involves the following steps:

$$
\begin{aligned}
& \mathrm{C}_{3} \mathrm{H}_{8} \mathrm{O}_{3}+\mathrm{X}_{1} \leftrightarrow \mathrm{C}_{3} \mathrm{H}_{8} \mathrm{O}_{3}-\mathrm{X}_{1} \\
& \mathrm{H}_{2} \mathrm{O}+\mathrm{X}_{2} \leftrightarrow \mathrm{H}_{2} \mathrm{O}-\mathrm{X}_{2} \\
& \mathrm{C}_{3} \mathrm{H}_{8} \mathrm{O}_{3}-\mathrm{X}_{1}+\mathrm{H}_{2} \mathrm{O}-\mathrm{X}_{2} \rightarrow \mathrm{HCOO}-\mathrm{X}_{2}+\mathrm{CH}_{2} \mathrm{OHCHOH}-\mathrm{X}_{1}+2 \mathrm{H}_{2} \\
& \mathrm{HCOO}-\mathrm{X}_{2} \rightarrow \mathrm{CO}_{2}+\mathrm{H}-\mathrm{X}_{2} \\
& \mathrm{CH}_{2} \mathrm{OHCHOH}-\mathrm{X}_{1}+\mathrm{H}-\mathrm{X}_{2} \rightarrow \mathrm{CH}_{2} \mathrm{OH}-\mathrm{X}_{1}+\mathrm{CH}_{3} \mathrm{O}-\mathrm{X}_{2} \\
& \mathrm{CH}_{2} \mathrm{OH}-\mathrm{X}_{1}+\mathrm{X}_{2} \rightarrow \mathrm{CH}_{2}-\mathrm{X}_{1}+\mathrm{OH}-\mathrm{X}_{2} \\
& \mathrm{CH}_{2}-\mathrm{X}_{1}+\mathrm{H}-\mathrm{X}_{2} \rightarrow \mathrm{CH}_{3}-\mathrm{X}_{1}+\mathrm{X}_{2} \\
& \mathrm{CH}_{3}-\mathrm{X}_{1}+\mathrm{H}-\mathrm{X}_{2} \rightarrow \mathrm{CH}_{4}+\mathrm{X}_{1}+\mathrm{X}_{2} \\
& \mathrm{CH}_{3} \mathrm{O}-\mathrm{X}_{1}+\mathrm{X}_{2} \rightarrow \mathrm{CH}_{2} \mathrm{O}-\mathrm{X}_{1}+\mathrm{H}-\mathrm{X}_{2} \\
& \mathrm{CH} \mathrm{O}-\mathrm{X}_{1}+\mathrm{X}_{2} \rightarrow \mathrm{HCO}-\mathrm{X}_{1}+\mathrm{H}-\mathrm{X}_{2} \\
& \mathrm{CO}-\mathrm{X}_{1}+\mathrm{OH}-\mathrm{X}_{2} \leftrightarrow \mathrm{CO} \mathrm{X}_{2}+\mathrm{H}-\mathrm{X}_{2}+\mathrm{X}_{1} \\
& \mathrm{HCO}-\mathrm{X}_{1}+\mathrm{X}_{2} \rightarrow \mathrm{CO}-\mathrm{X}_{1}+\mathrm{H}-\mathrm{X}_{2} \\
& \mathrm{CO}+\mathrm{X}_{1} \\
& \mathrm{CH}_{2} \\
& \mathrm{CO}
\end{aligned}
$$


where $X_{1}$ and $X_{2}$ represent the basic and the acid active sites, respectively. The authors suggested that surface reaction was rate-controlling, and so the following kinetic expression was proposed [108]:

$$
r=\frac{k p_{G} p_{W}}{\left(1+K_{G} p_{G}\right)\left(1+K_{W} p_{W}\right)}
$$

where $K_{G}$ and $K_{W}$ are the adsorption constants of glycerol and steam, respectively. In another work, Cheng et al. [134] concluded that the GSR reaction rate over a $\mathrm{Ni} / \mathrm{Al}_{2} \mathrm{O}_{3}$ supported catalyst is better described by a Langmuir-Hinshelwood model considering molecular adsorption of glycerol and dissociative chemisorption of steam, on two different sites, with the surface reaction as rate-determining step. The authors proposed the following mechanism represented by eq. (31-44).

$$
\begin{aligned}
& \mathrm{C}_{3} \mathrm{H}_{8} \mathrm{O}_{3}+\mathrm{X}_{1} \leftrightarrow \mathrm{C}_{3} \mathrm{H}_{8} \mathrm{O}_{3}-\mathrm{X}_{1} \\
& \mathrm{H}_{2} \mathrm{O}+2 \mathrm{X}_{2} \leftrightarrow \mathrm{OH}-\mathrm{X}_{2}+\mathrm{H}-\mathrm{X}_{2} \\
& \mathrm{C}_{3} \mathrm{H}_{8} \mathrm{O}_{3}-\mathrm{X}_{1}+\mathrm{H}-\mathrm{X}_{2} \rightarrow \mathrm{CH}_{2} \mathrm{OHCHOH}-\mathrm{X}_{1}+\mathrm{CHOH}-\mathrm{X}_{2}+2 \mathrm{H}_{2} \\
& \mathrm{CHOH}-\mathrm{X}_{2} \rightarrow \mathrm{CO}-\mathrm{X}_{2}+\mathrm{H}_{2} \\
& \mathrm{CH}_{2} \mathrm{OHCHOH}-\mathrm{X}_{1}+\mathrm{H}-\mathrm{X}_{2} \rightarrow \mathrm{CH}_{2} \mathrm{OH}-\mathrm{X}_{1}+\mathrm{CH}_{3} \mathrm{O}-\mathrm{X}_{2} \\
& \mathrm{CH}_{2} \mathrm{OH}-\mathrm{X}_{1}+\mathrm{X}_{2} \rightarrow \mathrm{CH}_{2}-\mathrm{X}_{1}+\mathrm{OH}-\mathrm{X}_{2} \\
& \mathrm{CH}_{2}-\mathrm{X}_{1}+\mathrm{H}-\mathrm{X}_{2} \rightarrow \mathrm{CH}_{3}-\mathrm{X}_{1}+\mathrm{X}_{2} \\
& \mathrm{CH}_{3}-\mathrm{X}_{1}+\mathrm{H}-\mathrm{X}_{2} \rightarrow \mathrm{CH}_{4}-\mathrm{X}_{1}+\mathrm{X}_{2} \\
& \mathrm{CH}_{3} \mathrm{O}-\mathrm{X}_{1}+\mathrm{X}_{2} \rightarrow \mathrm{CH}_{2} \mathrm{O}-\mathrm{X}_{1}+\mathrm{H}-\mathrm{X}_{2} \\
& \mathrm{CH}_{2} \mathrm{O}-\mathrm{X}_{1}+\mathrm{X}_{2} \rightarrow \mathrm{HCO}-\mathrm{X}_{1}+\mathrm{H}-\mathrm{X}_{2} \\
& \mathrm{HCO}-\mathrm{X}_{1}+\mathrm{X}_{2} \rightarrow \mathrm{CO}-\mathrm{X}_{1}+\mathrm{H}-\mathrm{X}_{2} \\
& \mathrm{CO}-\mathrm{X}_{1} \leftrightarrow \mathrm{CO}+\mathrm{X}_{1} \\
& \mathrm{CO}-\mathrm{X}_{1}+\mathrm{OH}-\mathrm{X}_{2} \leftrightarrow \mathrm{CO}+\mathrm{H}-\mathrm{X}_{2}+\mathrm{X}_{1} \\
& \mathrm{H}-\mathrm{X}_{2}+\mathrm{H}-\mathrm{X}_{2} \leftrightarrow \mathrm{H}_{2}+2 \mathrm{X}_{2}
\end{aligned}
$$

This mechanism yielded the following rate equation [134]: 


$$
r=\frac{k P_{G} \sqrt{P_{W}}}{\left(1+K_{G} P_{G}\right)\left(1+\sqrt{K_{W} P_{W}}\right)}
$$

In another mechanistic study, Byrd et al. [15] observed the presence of very low concentrations of organic carbon in the product stream, which suggests that intermediates like alcohols or organic acids, formed from C-O cleavage, were further transformed into gaseous products. For this reason, a different mechanism was proposed to describe the GSR over the $5 \% \mathrm{Ru} / \mathrm{Al}_{2} \mathrm{O}_{3}$ catalyst [114] and was also admitted to be valid for the $15 \mathrm{wt} . \%$ $\mathrm{Ni} / \mathrm{CeO}_{2}$ one [50]. This mechanism involves the reversible adsorption of glycerol on the catalyst active sites followed by its reaction with water, thus forming an adsorbed complex molecule. This complex on its hand decomposes into intermediate products, which irreversibly yield $\mathrm{H}_{2}$ and $\mathrm{CO}_{2}$. These steps are described by the following equations:

$$
\begin{aligned}
& \mathrm{C}_{3} \mathrm{H}_{8} \mathrm{O}_{3}+\mathrm{X} \stackrel{k_{1}, k_{-1}}{\longrightarrow} \mathrm{C}_{3} \mathrm{H}_{8} \mathrm{O}_{3}-\mathrm{X} \\
& \mathrm{C}_{3} \mathrm{H}_{8} \mathrm{O}_{3}-\mathrm{X}+\mathrm{H}_{2} \mathrm{O} \stackrel{k_{2}}{\rightarrow} \text { Complex-X} \\
& \text { Complex-X } \stackrel{k_{3}}{\rightarrow} \text { Intermediates } \stackrel{k_{4}}{\rightarrow} \mathrm{CO}_{2}+\mathrm{H}_{2}
\end{aligned}
$$

By applying steady state hypothesis to $\mathrm{C}_{3} \mathrm{H}_{8} \mathrm{O}_{3}-\mathrm{X}$ and Complex-X and assuming that the decomposition of Complex-X into intermediate products is the rate-determining step, the reaction rate was expressed as [50, 114]:

$$
r=\frac{k_{1} k_{2} p_{G} p_{W}}{\left[k_{-1}+k_{1} p_{G}+k_{2} p_{W}+\left(k_{1} k_{2} p_{G} p_{W} / k_{3}\right)\right]}
$$

Considering that water is in excess and that the operation pressure is constant, $p_{W}$ can be assumed to be almost equal to $p_{W 0}$. Therefore, eq. (49) is simplified to:

$$
r=\frac{k p_{G}}{1+b p_{G}}
$$

where $k$ and $b$ are defined as:

$$
\begin{aligned}
& k=\frac{k_{1} k_{2} p_{W 0}}{k_{-1}+k_{2} p_{W 0}} \\
& b=\frac{k_{1}+\left(k_{1} k_{2} p_{W 0} / k_{3}\right)}{k_{-1}+k_{2} p_{W 0}}
\end{aligned}
$$


Carbon deposition, as already discussed, is one of the most common causes of catalyst deactivation in GSR reaction. The influence of carbon deposition on the physical properties of the catalyst has already been discussed, as well as the nature of these deposits. On the other hand, the determination of carbon deposition kinetics is very helpful in terms of creation of more realistic reactor models, and better reactor design and operation. Cheng et al. [136] observed that the coke deposition rate on a 5 wt.\% Co10 wt.\% $\mathrm{Ni} / \mathrm{Al}_{2} \mathrm{O}_{3}$ catalyst during GSR can be relatively well described by a power-law model as follows:

$$
r_{\text {coke deposition }}=k_{C} p_{G}^{a} p_{W}^{b}
$$

where $k_{C}$ is the coke deposition reaction rate constant. At temperatures between 500-550 ${ }^{\circ} \mathrm{C}$ and glycerol partial pressures between 4.5-16.5 kPa, the parameters $a$ and $b$ were determined to be 0.55 and -0.22 , respectively, being the activation energy $40.9 \mathrm{~kJ} \cdot \mathrm{mol}^{-1}$. These values were found to be lower than those obtained for carbon deposition caused by $\mathrm{C}_{3} \mathrm{H}_{8}$ [137, 138], which is structurally very similar to glycerol. Regarding the lower activation energy, it may be explained by the presence of the functional $\mathrm{OH}$ group on each of the carbon atoms in the parent chain of glycerol, which makes it more reactive than propane (less electron-withdrawing $\mathrm{H}$ on each $\mathrm{C}$ atom). Moreover, the equilibrium constant of propane dehydrogenation into hydrogen and carbon is lower than that of glycerol decomposition into carbon. Therefore, the authors concluded that the adsorption of glycerol is stronger than for propane, in other words, it leads to easier carbon deposition [136]. Keeping this in mind and considering the empirical rate law, it was suggested that glycerol adsorbs dissociatively while steam is molecularly chemisorbed. Therefore, a Langmuir-Hinshelwood rate model considering a bimolecular rate-controlling step was proposed [136], yielding the following rate equation for coke deposition.

$$
r_{\text {coke deposition }}=\frac{k_{C} p_{W} \sqrt{p_{G}}}{\left(1+K_{W} P_{W}+\sqrt{K_{G} p_{G}}\right)^{2}}
$$




\section{Sorption-Enhanced Reactors}

In the last years, alternatives for improving the catalytic GSR process have been investigated. The main common reason that motivates this search is the necessity of overcoming equilibrium limitations, and also producing highly pure hydrogen that is suitable to be used in PEMFCs, for example. One of those alternatives is the Sorption Enhanced GSR (SEGSR) process, which consists on combining the catalytic GSR and $\mathrm{CO}_{2}$ capture in the same physical device. This innovative configuration allows "affecting" the thermodynamic equilibrium of the GSR reaction by removing one of the reaction products from the reaction medium. Some of the more important advantages of sorption-enhanced reactors (SER) comparatively to tradition reactors (TR) are:

- Shift the equilibrium of reversible reactions towards higher conversions;

- Enhancement of both hydrogen yield and selectivity;

- Attainment of better performance than in a TR at the same (or even less drastic) operating conditions.

However, the main disadvantage of this system is that the $\mathrm{CO}_{2}$ sorbent gets saturated at some point and then regeneration is necessary. In order to be possible to run continuously, the system must encompass, for example, two reactors, being that while one of them is used as SER the other is used as regenerator; the approach is the same as used in other cyclic processes like PSA (Pressure Swing Adsorption), etc. Another example of such a continuous SEGSR system is presented in Fig. 18 [139]. Besides the two moving-bed reactors in which both catalyst and sorbent are moved at a velocity of $9-11 \mathrm{~cm} \cdot \mathrm{min}^{-1}$, a riser is used for transporting the particles with $\mathrm{N}_{2}$. There is also a system for injecting the particles of catalyst and sorbent at the top of the reactor (cyclone section) in order to compensate for the losses during the runs, which amount is close to $5 \%$ every 5 min [139].

The successful use of SERs for GSR depends, above all, on choosing an adsorbent with suitable characteristics and selecting appropriate operating conditions. Such matters are target of focus in the following section.

\section{$5.1 \mathrm{CO}_{2}$ Sorbents}

Different materials like hydrotalcites [140-144], CaO-based materials [145-149], lithium zirconates [150-154] and lithium silicates [155-159], among others, have been 
reported in the literature as $\mathrm{CO}_{2}$ sorbents for SERs applications. It is expected from a good $\mathrm{CO}_{2}$ sorbent to couple in a GSR process to present high $\mathrm{CO}_{2}$ capture capacity and selectivity at moderated temperatures $\left(300-500{ }^{\circ} \mathrm{C}\right)$, good regenerability (adequate sorptiondesorption kinetics), good hydrothermal and mechanical stability and low-cost [160-163]. The sorption capacities and sorption/regeneration temperatures of several sorbents are summarized is Table 9.

Hydrotalcites are a family of clay minerals that consist of a double-layered hydroxide structure with the general formula $\left[\mathrm{M}_{x}^{\prime \prime} \mathrm{M}^{\prime \prime \prime}{ }_{(1-x)}(\mathrm{OH})_{2}\right]\left[\mathrm{A}^{n-}\right]_{x / n} \cdot m \mathrm{H}_{2} \mathrm{O}$, where $\mathrm{M}^{\prime \prime}$ and $M^{\prime \prime \prime}$ represent di- and trivalent metal ions inside the brucite-like layers and $A^{n-}$ is a charge compensating anion [143, 167]. Aschenbrenner et al. [143] observed that NiMgAl hydrotalcite presented 53\% more adsorption capacity than NiMgAlFe hydrotalcite and high stability. A comparison between a commercial hydrotalcite and two potassium and potassium-sodium containing hydrotalcites allowed to conclude that the last one presented the highest adsorption capacity while the potassium containing hydrotalcite presented no significative deactivation after more than 50 cycles of operation [142]. Kdoped hydrotalcite-based sorbents have been reported elsewhere to present a $\mathrm{CO}_{2}$ capture capacity as high as $9 \mathrm{~mol} \cdot \mathrm{kg}^{-1}$ at $300{ }^{\circ} \mathrm{C}$ but under wet conditions (Table 9) [141]. Under dry conditions, the maximum value reported was around $1.8 \mathrm{~mol} \cdot \mathrm{kg}^{-1}$ (Table 9), which is an outstanding value taken into account the temperature $\left(300{ }^{\circ} \mathrm{C}\right)$ and that it was not tested under the presence of steam. It has also been found that the physical and chemical properties of hydrotalcites are highly influenced by the charge compensating anion used. Wang et al. [168] analyzed several charge compensating anions $\left(\mathrm{CO}_{3}{ }^{2-} ; \mathrm{HCO}_{3}{ }^{-} ; \mathrm{NO}^{3-} ; \mathrm{SO}_{4}{ }^{2-}\right.$; and $\mathrm{Cl}^{-}$) having observed that when using $\mathrm{CO}_{3}{ }^{2-}$, a spheroidal "sand rose" type of hydrotalcite with very high BET surface area $\left(114.3 \mathrm{~m}^{2} \cdot \mathrm{g}^{-1}\right)$ was produced. On the other hand, the other anions led to the formation of "stone" type hydrotalcites with very low surface areas $\left(<9 \mathrm{~m}^{2} \cdot \mathrm{g}^{-1}\right)$. For this reason, the $\mathrm{Mg}_{3} \mathrm{Al}_{1}-\mathrm{CO}_{3}$ hydrotalcite presented the highest $\mathrm{CO}_{2}$ capture capacity. The thermal stability was also found to depend on the anion used, being that the $\mathrm{Mg}_{3} \mathrm{Al}_{1}-\mathrm{SO}_{4}$ was the one that presented the highest thermal stability.

Other adsorbents like CaO-based materials, and lithium zirconates and silicates present in general a lower $\mathrm{CO}_{2}$ capacity and slower adsorption kinetics at $300-400{ }^{\circ} \mathrm{C}$, higher regeneration temperature $\left(>650^{\circ} \mathrm{C}\right)$ and gradual deactivation due to sintering of the active surface [140]. They have however significant adsorption capacities, but at much higher temperatures (Table 9). Wang et al. [145] avoided sintering of nano $\mathrm{CaCO}_{3}$ during 
multiple carbonation/calcination cycles by applying a $\mathrm{TiO}_{2}$ coating. Akgsornpeak et al. [149] avoided the same problem by preparing $\mathrm{CaO}$ sorbents through sol-gel synthesis in the presence of cetyltrimethyl ammonium bromide (CTAB). Besides that, the CaO sorbents prepared with $\mathrm{CTAB}$ also exhibited high carbonation reaction rates, and the best $\mathrm{CaO}$ sorbent presented carbonation conversion $154 \%$ more effective than the $\mathrm{CaO}$ prepared in the absence of $C T A B$. The incorporation of $\mathrm{Y}_{2} \mathrm{O}_{3}$ has been recently reported to significantly enhance the carbonation rate and adsorption capacity of $\mathrm{CaO}$-based $\mathrm{CO}_{2}$ sorbents [147]. Similarly to hydrotalcites, the addition of optimized amounts of $\mathrm{K}$ to $\mathrm{Li}_{2} \mathrm{ZrO}_{3}$ sorbents was reported to enhance its $\mathrm{CO}_{2}$ sorption rate and capacity. Moreover, they showed good stability [152]. However, Lapkin and co-workers [154] came to the conclusion that a traditional route to $\mathrm{K}$-doped materials result in slow regeneration. On the other hand, a new soft chemistry route that produces high surface area undoped materials led to much higher rates of reaction/regeneration. Seggiani et al. [156] analyzed the performance of different doped- $\mathrm{Li}_{4} \mathrm{SO}_{4} \mathrm{CO}_{2}$ sorbents, having observed that the $\mathrm{K}$-doped and $\mathrm{Na}$-doped presented the highest $\mathrm{CO}_{2}$ sorption capacities and sorption rates. In terms of stability, only the potassium-doped sorbent was able to keep its properties after 25 sorption/desorption cycles. In another work, it was shown that $\mathrm{Li}_{4} \mathrm{SiO}_{4}$ treated with glacial acetic acid presented stable $\mathrm{CO}_{2}$ sorption capacity, higher specific surface area and higher porosity than limestone and $\mathrm{Li}_{4} \mathrm{SiO}_{4}$ without acid treatment [157].

The decision on which kind of $\mathrm{CO}_{2}$ sorbent is more adequate to be used in SEGSR strongly depends on the operating temperature at which it will be employed. Since one of the main goals at the moment is to reduce the GSR temperature in order to reduce operation costs, it is desirable to work at relatively low temperatures $\left(300-500{ }^{\circ} \mathrm{C}\right)$. For such temperatures hydrotalcites have been reported to present higher $\mathrm{CO}_{2}$ capacities and faster sorption kinetics, as well as easier regeneration, and lower loss of sorption capacity $[140,141]$. Moreover, the fact that the $\mathrm{CO}_{2}$ capacity of hydrotalcites is strongly enhanced under wet conditions (steam reforming conditions) makes them an even better candidate for use in SEGSR.

\subsection{Sorption Enhanced Glycerol Steam Reforming}

The catalytic GSR performed in TRs presents some limitations as already mentioned, including the thermodynamic constrains. On the other hand, when $\mathrm{CO}_{2}$ capture 
is performed simultaneously with the GSR reaction in a SER, the thermodynamic equilibrium is shifted towards higher glycerol conversions and hydrogen yields. A typical evolution profile of the product gas composition ( $\mathrm{N}_{2}$ free and dry basis) in a SEGSR over a mixture of $\mathrm{Ni}-\mathrm{Co} /$ hydrotalcite-like catalyst and calcined dolomite as $\mathrm{CO}_{2}$ sorbent is illustrated in Fig. 19 [169]. The performance of the SEGSR is highly dependent on the $\mathrm{CO}_{2}$ capture. It can be seen in Fig. 19 that there are 3 distinct regimes along time: prebreakthrough, breakthrough and post-breakthrough. In the pre-breakthrough regime (up to $140 \mathrm{~min}$ ), most of the $\mathrm{CO}_{2}$ was removed by fast carbonation reaction with $\mathrm{CaO}$, thus enhancing hydrogen production. In the breakthrough regime the $\mathrm{H}_{2}$ concentration starts decreasing. In the post-breakthrough regime the $\mathrm{CaO}$ sorbent is already saturated and so the enhancement of hydrogen production due to $\mathrm{CO}_{2}$ removal disappears; at this stage the SEGSR becomes GSR (conventional fixed-bed reactor).

In the following sections are shown the effects of the main operating conditions in the SEGSR, comparing, whenever possible, with the thermodynamic equilibrium.

\subsubsection{Effect of Temperature}

The influence of temperature on the performance of a SEGSR reactor has been analyzed by several authors, due to the crucial importance of choosing an appropriate temperature range in order to fully benefit of the advantages of this innovative reactionseparation system.

Chen et al. [44] compared the product gas composition of a GSR reactor obtained with and without in situ $\mathrm{CO}_{2}$ removal, and each of them with the respective thermodynamic equilibrium limits. Such comparison is depicted in Fig. 20 [44]. The SEGSR tests were performed until the calcined dolomite was saturated, being that from that point on the GSR took place. A Co-Ni/hydrotalcite-like catalyst and ARCTIC dolomite (98.5\% $\left.\mathrm{CaMg}\left(\mathrm{CO}_{3}\right)_{2}\right) \mathrm{CO}_{2}$ sorbent were used. Regarding the GSR product gas composition, the thermodynamic equilibrium trends are in general followed by $\mathrm{CO}$ and $\mathrm{CH}_{4}$. However, the $\mathrm{H}_{2}$ content is slightly higher and the $\mathrm{CO}_{2}$ content is slightly lower than the equilibrium values for GSR. The authors suggested that this happened because of the very slow $\mathrm{CO}_{2}$ removal by the dolomite sample in the second carbonation regime (i.e. the reactor was not yet operating as a conventional GSR one, because some carbon dioxide sorption was still occurring). By comparing both SEGSR and GSR it is observed, as expected, that the in 
situ selective removal of $\mathrm{CO}_{2}$ enhanced the hydrogen production and originated a lower CO content due to the promotion/shift of the WGS reaction equilibrium, which consequently promoted SRM. Both experimental and thermodynamic equilibrium gas composition values are in agreement for SEGSR. In terms of the effect of temperature, a compromise between the WGS reaction, $\mathrm{SRM}$ and $\mathrm{CO}_{2}$ sorption has to be considered. At higher temperatures, both exothermic WGS reaction and $\mathrm{CO}_{2}$ sorption are less favored while the endothermic SRM is benefited. As can be seen for SEGSR, both $\mathrm{CO}$ and $\mathrm{CO}_{2}$ contents increase with temperature, being that $\mathrm{CO}$ is more influenced because of both the increase of $\mathrm{CO}_{2}$ concentration in the adsorption equilibrium and decrease of the WGS reaction equilibrium constant. The methane content, on the other hand, decreased since high temperatures favor SRM. Finally, the hydrogen purity decreased as well due to the presence of higher amounts of $\mathrm{CO}$ and $\mathrm{CO}_{2}$.

Dou et al. [122, 170] analyzed the purity of hydrogen as a function of time at distinct temperatures $\left(400-700{ }^{\circ} \mathrm{C}[122]\right.$ and $500-700^{\circ} \mathrm{C}$ [170]) while using dolomite as $\mathrm{CO}_{2}$ sorbent. As expected, the highest hydrogen purity was obtained in the pre- $\mathrm{CO}_{2}$ breakthrough period. The periods of production of hydrogen with purity higher than $90 \%$ were 3.6, 6.8 and $5 \mathrm{~min}$ at 400,500 and $600{ }^{\circ} \mathrm{C}$, respectively. At $700{ }^{\circ} \mathrm{C}$, the maximum $\mathrm{H}_{2}$ purity was $77 \%$ with a $\mathrm{CO}_{2}$ breakthrough time of $0.7 \mathrm{~min}$ [122]. A similar behavior was observed in [170]. The authors suggest that the effect of SEGSR was particularly low at $700{ }^{\circ} \mathrm{C}$ because the carbonate decomposition (calcination) in the presence of steam is significantly active at that temperature for dolomite. Moreover, the calcined dolomite presents some affinity towards steam in order to form $\mathrm{Ca}(\mathrm{OH})_{2}$ (eq. (13)). In another work, Dou and co-workers [139] observed that the high-purity hydrogen production period did not vary much when the operation temperature was increased from $500^{\circ} \mathrm{C}$ to $600{ }^{\circ} \mathrm{C}$, while using $\mathrm{CaO}$ as $\mathrm{CO}_{2}$ sorbent. Chen et al. [171] observed, while using an hydrotalcite $\mathrm{CO}_{2}$ sorbent, a decrease of the GSR enhancement when the temperature was increased from 400 to $500{ }^{\circ} \mathrm{C}$. Thus, the operating temperature should be chosen so that the GSR enhancement caused by in situ $\mathrm{CO}_{2}$ capture is maximized.

\subsubsection{Effect of the Water/Glycerol Feed Ratio}

It is well known that the WGFR has an important influence on the GSR reaction. It was verified in section 2.2 that increasing the WGFR affects the thermodynamic 
equilibrium of the SEGSR process. However, in actual operation additional effects may occur. Such effects are target of discussion here.

Chen and co-workers [44] analyzed the performance of the SEGSR for different values of WGFR in the range of 3-9. A comparison between the evolution of product composition with time on stream at WGFRs of 3, 4 and 9 was done. During the pre- $\mathrm{CO}_{2}$ breakthrough period, in particular, the authors observed that for a WGFR of 9 the maximum $\mathrm{H}_{2}$ purity is higher than that for a WGFR of 3 . Moreover, at the lower WGFR the $\mathrm{H}_{2}$ purity decreased with time on stream. This decay was caused exclusively by the gradual increase of the methane content, since both $\mathrm{CO}_{2}$ and $\mathrm{CO}$ content remained almost constant and low. The authors suggested that the relatively high methane content was not exclusively due to methanation reaction, since only low amounts of $\mathrm{CO}_{2}$ and $\mathrm{CO}$ were present in the gas phase and in the catalyst surface. Thus, considering that SEGSR was performed at high temperatures and glycerol is thermally unstable, the pyrolysis of glycerol to yield $\mathrm{CH}_{4}, \mathrm{CO}_{2}, \mathrm{H}_{2} \mathrm{O}$, coke and volatiles may have happened even before glycerol reached or passed through the catalyst bed. Therefore, pyrolysis of glycerol may have occurred and caused the carbonaceous deposits that were found on the front of the reactor bed and that led to catalyst deactivation. At a WGFR of 4 the purity of $\mathrm{H}_{2}$ was lower than that for a WGFR of 9, however gradual decrease of the $\mathrm{H}_{2}$ content due to methane formation through glycerol pyrolysis was not observed at such water content as compared to WGFR of 3.

A comparison between the $\mathrm{H}_{2}$ yields obtained experimentally and in the thermodynamic equilibrium at different WGFRs was also done by Chen et al. [44]. The biggest difference was obtained for a WGFR of 3. This happened because of the pyrolysis of glycerol that hindered hydrogen production by favoring the formation of $\mathrm{CH}_{4}, \mathrm{CO}_{2}$ and carbon deposits. As the WGFR increased, the experimental $\mathrm{H}_{2}$ yield went close to the thermodynamic boundaries, being that at a WGFR of 9 the experimental $\mathrm{H}_{2}$ yield achieved the theoretical maximum value. In another work, Chen et al. [169] obtained lower $\mathrm{H}_{2}$ yields than in [44] using the same WGFR of 9 but at $550^{\circ} \mathrm{C}$. They suggested that this lower performance was associated to the formation of carbonaceous deposits through glycerol pyrolysis. The reason for such difference is that while in [44] pure glycerol was used, in [169] Chen's group used crude glycerol, whose impurities lead to pyrolysis, thus enhancing coke formation.

Wang et al. [172] analyzed the impact of changing the WGFR from 6 to 9 on the product composition (dry basis) of SEGSR. While for a WGFR of 6 a dry product composition 
of $87 \% \mathrm{H}_{2}, 9 \% \mathrm{CH}_{4}, 3 \% \mathrm{CO}$ and $1 \% \mathrm{CO}_{2}$ was attained, for a WGFR of 9 a dry product composition of $95 \% \mathrm{H}_{2}$ and $5 \%$ of $\mathrm{CH}_{4}$ was reached. This is due to the enhancement of GSR performance at higher WGFRs. Even though the $\mathrm{H}_{2}$ concentrations obtained for both cases were high, they were still below the thermodynamic values. Methane concentrations, on the other hand, were higher than the thermodynamic values, which the authors suggested to be due to lack of activity to convert excess methane into hydrogen with the $\mathrm{Ni} / \mathrm{ZrO}_{2}$ catalyst used.

On the other hand, the steam content has been reported to influence the capacity of $\mathrm{CO}_{2}$ sorbents [141, 142]. By comparing the adsorption capacity of hydrotalcite-based sorbents under dry and wet conditions, Martunus et al. [142] and Maroño et al. [141] concluded that under wet conditions the $\mathrm{CO}_{2}$ capture capacities of the sorbents were higher. Dou et al. [170] compared the performance of SEGSR using crude glycerol and pure glycerol in the same conditions, having come to the conclusion that when crude glycerol was used longer breakthrough times were observed. This might be explained by the fact that steam conversions obtained while using crude glycerol were approximately half of those obtained for pure glycerol, thus resulting in higher steam partial pressures in the reactor when crude glycerol was used. However, excessive amounts of steam may lead to reduction of $\mathrm{CO}_{2}$ capture capacity of sorbents, since it causes shrinkage of pore mouths due to adsorption of both steam and $\mathrm{CO}_{2}$ on the active sorbent surfaces, especially near the pore mouth. Consequently, the pores may be closed, thus increasing the diffusional resistance [142].

\subsubsection{Effect of Pressure}

It was discussed in section 2 that, in equilibrium, lower pressures favor the production of hydrogen through both GSR and SEGSR and lead to low carbon formation, especially for SEGSR. Chen and co-workers [171] observed that by increasing the operation pressure, the hydrogen yield decreased for both GSR and SEGSR (Fig. 21 [171]). However, as expected, higher values of hydrogen yield were obtained in SEGSR for all pressure range. Moreover, it was observed that the difference between the values of $\mathrm{H}_{2}$ yield in GSR and SEGSR increased with pressure, as can be seen in Fig. 21. This happens because higher pressures favor $\mathrm{CO}_{2}$ sorption. Therefore higher pressures allow taking more advantage of the benefits of the SEGSR process. 


\section{Membrane Reactors}

The International Union of Pure and Applied Chemistry (IUPAC) defined MR as a device for simultaneously carrying out a reaction and a membrane-based separation in the same physical enclosure [173]. In a MR the membrane not only selectively separates one or more components but also plays a crucial role, e.g. in overcoming the thermodynamic boundaries of equilibrium-limited reactions like the GSR. Regarding its advantages compared to TRs, they are basically the same as SERs, with exception to the reduction of $\mathrm{CO}_{2}$ emissions, being that the capital costs reduction is even higher in the case of MRs since only one reactor is needed instead of two reactors. In fact, this cost reduction is feasible as long as cheap and long-lasting membranes can be produced. Moreover, in MRs it is possible to produce ultra-pure hydrogen streams. The scheme of a MR for GSR is presented in Fig. 22 [174]. In this particular case, a hydrogen perm-selective membrane is used to selectively separate hydrogen from the other components; however, a $\mathrm{CO}_{2}$ perm-selective membrane could be used instead. Still, since one of the main goals of using MRs for GSR reaction is to produce ultra-pure hydrogen that can later be used in PEMFCs, it is preferable to use a $\mathrm{H}_{2}$ perm-selective membrane in order to isolate $\mathrm{H}_{2}$ instead of using $\mathrm{CO}_{2}$ perm-selective membranes and having $\mathrm{H}_{2}$ mixed with steam, some unreacted $\mathrm{CO}$ and glycerol.

In order to fully use all the capacities of MRs, it is fundamental that an appropriate hydrogen perm-selective membrane is used and that the right operating conditions are selected. Therefore, the following sections comprise a short overview on hydrogen permselective membranes reported in the literature as well as an analysis of experimental parametric studies on GSR in MRs.

\subsection{Hydrogen perm-selective membranes for membrane reactors}

Hydrogen perm-selective membranes may be classified as dense metallic membranes (palladium and palladium alloys), proton conducting dense ceramic membranes (perovskites like $\mathrm{SrCeO}_{3-\delta}$ and $\mathrm{BaCeO}_{3-\delta}$ ), dense polymeric membranes (polyimide, cellulose acetate, polysulfone, etc), microporous ceramic membranes (silica, alumina, zirconia, titania, zeolites, metal-organic frameworks (MOF)) and porous carbon 
membranes (carbon) $[175,176]$. The main advantage of dense metallic membranes is that usually they withstand high temperatures (e.g. as compared to polymeric ones) and present higher selectivity towards $\mathrm{H}_{2}$, thus being possible to obtain high purity hydrogenpermeate streams [175]. Therefore, dense metallic membranes are preferable for ultrapure hydrogen production and will be the main target of focus.

When choosing a membrane to be used in a MR, one has to consider the operating conditions under which the membrane will be used. In the last years there has been a tremendous effort in order to find suitable membranes for MR applications. Palladiumbased membranes are currently the most promising for high purity hydrogen production in MRs, especially palladium alloys (e.g. Pd-Ag and Pd-Cu) which are less sensitive than pure Pd to embrittlement (caused by the presence of $\mathrm{H}_{2}$ at temperatures below $300{ }^{\circ} \mathrm{C}$ and pressures below $2 \mathrm{MPa}$ ) and poisoning (caused by contact with $\mathrm{CO}$ or $\mathrm{H}_{2} \mathrm{~S}$ - present in crude glycerol) [175, 177]. Tosti et al. [178] verified that self-supported dense Pd-Ag 23 wt.\% tubular membranes with finger-type configuration are highly durable and reliable since they allowed to attain complete hydrogen selectivity and no failures were observed after at least one year of thermal and hydrogenation cycles. These characteristics, together with high permeability, make such materials very promising for ultra-pure hydrogen production in industrial and energetic applications (chemical industry, PEMFCs, etc.) [178]. However, the cost of these dense membranes is still a limiting factor, reason why a strong effort has been put in the preparation of thinner Pd films over different supports, by several techniques.

In terms of preparation methods, electroless plating (EP) and chemical vapor deposition (CVD) are the most used ones. The EP method normally consists on producing $\mathrm{Pd}$ particles through reduction of a plating solution containing Pd-amine complexes. This technique allows to attain high coating adhesion, involves low operation costs and allows simple operation. However, the impurities present in the plating solution may lead to the presence of defects on the palladium layer deposited on the support. The CVD technique allows to very easily deposit a metal film on a support. On the other hand, using both of these techniques it may be difficult to control the metal alloy composition [179].

Usually the permeation of hydrogen through a palladium-based membrane is described by a solution-diffusion mechanism, being that the flux of hydrogen that permeates through the membrane $\left(U_{H_{2}}\right)$ can be illustrated by the following equation: 


$$
J_{H_{2}}=P_{P d, H_{2}} /_{\delta}\left(p_{H_{2}, \text { retentate }}^{x}-p_{H_{2}, \text { permeate }}^{x}\right)
$$

where $P_{P d, H_{2}}$ is the permeability of the membrane, $\delta$ is the membrane thickness, $p_{H_{2}, \text { retentate }}$ and $p_{H_{2}, \text { permeate }}$ are the partial pressures of hydrogen in the retentate and in the permeate side, respectively, and $x$ is the pressure exponent. The ratio $\frac{P_{P d_{1} H_{2}}}{\delta}$ is normally called permeance or pressure normalized flux. The pressure exponent takes values between 0.5 and 1, being 0.5 (Sieverts law) when the diffusion of atomic hydrogen through the metal lattice of the membrane is the limiting step. On the other hand, the pressure exponent becomes close to 1 if the surface adsorption is rate limiting. The permeability is typically described by an Arrhenius-type dependency on the temperature:

$$
P_{P d, H_{2}}=P_{P d, H_{2}}^{0} \exp \left(-E_{a, P d} /_{R T}\right)
$$

where $P_{P d, H_{2}}^{0}$ is the pre-exponential factor and $E_{a, P d}$ is the activation energy of the membrane.

Table 10 encompasses a summary of different Pd-based membranes that have been reported in the last years. Some parameters such as membrane thickness, hydrogen permeance, ideal $\mathrm{H}_{2} / \mathrm{N}_{2}$ selectivity and activation energy are reported.

\subsection{Glycerol Steam Reforming in Membrane Reactors}

Experimental studies featuring the use of MRs for hydrogen production through several reactions (GSR, SRM, WGS, steam reforming of ethanol, etc.) have been extensively reported in the last decade. This growing interest in such technology is explained by the fact that, among other things, MRs allow to overcome the thermodynamic boundaries of equilibrium-limited reactions, thus allowing to reach high purity hydrogen streams that are suitable for use in PEMFCs. The experimental studies on GSR in MRs reported in the literature [190-193] accessed the effects of temperature, pressure and weight hourly space velocity (WHSV) and will be summarized in the next section.

\subsubsection{Effects of Temperature, Pressure and Weight Hourly Space Velocity}

In a MR, it was observed that, by increasing the operating temperature from 400 ${ }^{\circ} \mathrm{C}$ to $450{ }^{\circ} \mathrm{C}$, both glycerol conversion and hydrogen yield increased [190, 192]. This 
happens not only because of the endothermic nature of the GSR reaction, but also because at higher temperatures the Pd-Ag/PSS membrane becomes more permeable towards hydrogen (eq. (56)). Such enhancement in the performance was also proved by the observed increase in the hydrogen recovery (ratio between the amount of hydrogen collected in the permeate side and the total amount of hydrogen produced in the GSR reaction) when temperature was increased from $400{ }^{\circ} \mathrm{C}$ to $450{ }^{\circ} \mathrm{C}$ [190]. This way, a higher shift of the thermodynamic equilibrium at higher temperatures is observed.

When it comes to the successful operation of a MR, pressure is a fundamental parameter to be taken into consideration. As can be seen by analyzing eq. (55), higher differences between the retentate and permeate pressures (driving force) lead to higher permeating hydrogen fluxes. Therefore, higher driving forces favor the dislocation of the thermodynamic constraints (Fig. 23 [193]). On the other hand, the production of hydrogen through GSR reaction is not favored at higher pressures, as already discussed in previous sections and illustrated in the same figure. Thus, a compromise between these two factors must be taken into consideration, being, for the conditions employed in Fig. 23, the hydrogen permeation through the membrane the dominant one.

In terms of glycerol conversion, a clear increase was verified with the increase of pressure in several works with MRs [190, 192, 193]. However, lulianelli et al. [191] observed a high increase of glycerol conversion from 1.0 to 4.0 bar and a small decrease from 1.0 to 1.5 bar (Fig. 24 [191]). The authors suggested that this happens because while for the first case the enhancement of the hydrogen permeation prevails over the thermodynamic restrictions, for the second case the opposite occurs. Regarding the hydrogen yield, it increased less and, at higher pressures, it was observed that it stabilized or even decreased. This happens due to the occurrence of methanation reactions which consume hydrogen. Basile and co-workers [191] observed an increase of the methane selectivity as well as a decrease of hydrogen selectivity for increasing pressures. Such behavior is also due to the low capacity of the used Co-based catalyst to promote SRM [191]. Contrarily, the recovery of hydrogen increased even more rapidly at higher reaction pressures.

The use of an inert sweep gas to dilute the hydrogen in the permeate side and decrease its partial pressure has been one of the best ways of increasing the driving force for hydrogen permeation in MRs. Iulianelli et al. [191] analyzed the effect of the sweep factor (SF) (molar ratio between the sweep gas and the feed glycerol flow rates) on 
glycerol conversion and hydrogen recovery at different reaction pressures. By increasing the SF from 2.6 to 11.9 at 4.0 bar, the glycerol conversion increased from 55.0 to $92.0 \%$ (Fig. 24). However, for increasing SFs beyond 11.9 the enhancement of the glycerol conversion is very low. This happens because from a SF of 11.9 on, the increase in the dilution of the hydrogen in the permeate side is almost null and so the driving force almost does not increase. In terms of hydrogen recovery, the best result was around $63.0 \%$ and was obtained at 4.0 bar and SF of 22.8.

The effect of the WHSV has also been analyzed by lulianelli et al. [193]. The authors observed that increasing WHSV have a negative impact on the glycerol conversion and on both hydrogen yield and recovery. The lower the WHSV, the higher is the residence time of gases inside the reactor bed and so higher glycerol conversions and hydrogen yields are obtained. Higher residence times also allow hydrogen to permeate more easily, not only because of the higher amounts of hydrogen produced and thus higher driving force, but also because hydrogen has more time to reach the membrane surface and permeate.

Besides affecting the performance of the GSR catalyst, the deposition of carbonaceous deposits was also found to negatively affect the performance of the membrane in terms of hydrogen permeating flux [191]. Moreover, the presence of CO during GSR reaction is often responsible for the loss of membranes permeability, being far more important than $\mathrm{CO}_{2}$ [177]. One way of reducing this effect is to use higher WGFRs (e.g. 9). 


\section{Conclusions}

In the last decades hydrogen has been seen as a promising energy carrier to be used in energy systems. For this reason, different ways of producing hydrogen have been target of interest. However, most of these processes are based on the use of fossil origin raw materials (natural gas, naphtha, coal, etc.) whose environmental sustainability is highly questionable.

Glycerol produced as by-product in the biodiesel manufacturing process has been found to be a very attractive non-fossil alternative for hydrogen production. The GSR process is seen as one of the most promising ways of converting glycerol into hydrogen, mainly because its scale-up would not require many changes in the current industrial processes for hydrogen production from fossil fuels, which are mostly based on steam reforming. In order to enhance the GSR process performance for improved hydrogen production the choice of an appropriate catalyst is fundamental. Nickel and noble metals like platinum and ruthenium have been widely studied. While nickel catalysts are cheaper, noble metals are more active and stable, thus allowing to work at lower temperatures. Nonetheless, in the last years a huge effort has been put on the search for nickel-based catalysts whose performance is comparable to that of noble metal materials. The influence of catalyst supports must also be taken into consideration, being that neutral supports (e.g. $\mathrm{SiO}_{2}$ ) present higher stability and lower carbon deposition. The use of promoters may also be necessary in order to further improve the catalyst stability, a key issue in this field. Consequently, further research has to be done on this area, especially the search for low-temperature active and stable Ni-based catalysts.

Different mechanisms have been proposed for the GSR reaction (e.g. LangmuirHinshelwood dual site mechanism with molecular adsorption of glycerol and molecular or dissociative adsorption of water). However, a consensus on this matter hasn't been reached yet and so further studies are required. Moreover, since the GSR reaction highly promotes the formation of carbonaceous deposits, the study of the coke deposition kinetics has also been done, being that a Langmuir-Hinshelwood single site mechanism with dissociative adsorption of glycerol and molecular adsorption of water was proposed to describe the deposition of coke over a Co-Ni/ $\mathrm{Al}_{2} \mathrm{O}_{3}$ catalyst. Despite this, more focus on this subject is required as well, so that the possible existence of different mechanisms of coke deposition on other types of catalysts may be disclosed. 
Even if a good catalyst together with favoring operating conditions are used in catalytic GSR in a TR (e.g. fixed bed reactor), thermodynamic limitations in terms of glycerol conversion and hydrogen yield are still present. In order to avoid such constraints, intensified processes combining GSR reaction and $\mathrm{CO}_{2}$ or $\mathrm{H}_{2}$ selective removal in the same physical device have been found as an excellent alternative. It has been observed that removing $\mathrm{CO}_{2}$ or $\mathrm{H}_{2}$ from the reaction medium shifts the thermodynamic equilibrium towards higher glycerol conversions and higher hydrogen yields. Moreover, such processes allow to work at lower temperatures and attain similar or even better performances than TRs at higher temperatures. However, in order for the implementation of these processes be successful, $\mathrm{CO}_{2}$ sorbents with high sorption capacity, stability and low sorption and regeneration temperatures (e.g. $300-500{ }^{\circ} \mathrm{C}$ ), as well as hydrogen perm-selective membranes with high hydrogen selectivity and permeability and high resistance to embrittlement and poisoning have to be used. At the moment, hydrotalcite-based $\mathrm{CO}_{2}$ sorbents (that require lower sorption and regeneration temperatures) and Pd-based membranes are seen as promising systems for use in SEGSR and GSR in MRs, respectively, at lower temperatures $\left(300-400{ }^{\circ} \mathrm{C}\right)$. Moreover, appropriate operating conditions (temperature, WGFR, pressure and WHVS) have to be carefully chosen.

Regarding $\mathrm{CO}_{2}$ emissions, these can be easily avoided though SEGSR, however MRs with $\mathrm{H}_{2}$ perm-selective membranes are not efficient on this. On the other hand, highly pure $\mathrm{H}_{2}$ streams suitable for use in PEMFCs can only be produced in MRs. Therefore, new solutions combining catalytic GSR with in situ $\mathrm{CO}_{2}$ and $\mathrm{H}_{2}$ removal would be interesting to explore.

\section{Acknowledgements}

Joel M. Silva acknowledges the Doctoral Program in Chemical and Biological Engineering from FEUP for the PhD grant. M.A. Soria is grateful to the FCT for the postdoctoral grant (SFRH/BD/88444/2012). 


\section{References}

[1] Zhou C-H, Beltramini JN, Fan Y-X, Lu GQ. Chemoselective catalytic conversion of glycerol as a biorenewable source to valuable commodity chemicals. Chemical Society Reviews. 2008;37:52749.

[2] Dou B, Song $\mathrm{Y}$, Wang $\mathrm{C}$, Chen $\mathrm{H}, \mathrm{Xu} \mathrm{Y}$. Hydrogen production from catalytic steam reforming of biodiesel byproduct glycerol: Issues and challenges. Renewable and Sustainable Energy Reviews. 2014;30:950-60.

[3] U.S. Energy Information Administration.

[4] Avasthi KS, Reddy RN, Patel S. Challenges in the Production of Hydrogen from Glycerol - A Biodiesel Byproduct Via Steam Reforming Process. Procedia Engineering. 2013;51:423-9.

[5] Ewan BCR, Allen RWK. A figure of merit assessment of the routes to hydrogen. International Journal of Hydrogen Energy. 2005;30:809-19.

[6] Liu Y, Farrauto R, Lawal A. Autothermal reforming of glycerol in a dual layer monolith catalyst. Chemical Engineering Science. 2013;89:31-9.

[7] Liu Y, Lawal A. Synthesis gas production by autothermal reforming of crude glycerol using a dual layer monolith catalyst. 2013.

[8] Nahar G, Dupont V. Recent advances in hydrogen production via autothermal reforming process (ATR): A review of patents and research articles. Recent Patents on Chemical Engineering. 2013;6:8-42.

[9] Wang W. Thermodynamic analysis of glycerol partial oxidation for hydrogen production. Fuel Processing Technology. 2010;91:1401-8.

[10] Camargo G, Cardozo S, Pena MV. Thermodynamical analysis of glycerol partial oxidation reaction using zeolites catalyst. 2012 AIChE Annual Meeting, AIChE 2012, October 28, 2012 November 2, 2012. Pittsburgh, PA, United states: American Institute of Chemical Engineers; 2012.

[11] Liu S-K, Lin Y-C. Autothermal partial oxidation of glycerol to syngas over Pt-, LaMnO 3-, and Pt/LaMnO3-coated monoliths. Industrial and Engineering Chemistry Research. 2012;51:1627887.

[12] Tuza PV, Manfro RL, Ribeiro NFP, Souza MMVM. Production of renewable hydrogen by aqueous-phase reforming of glycerol over $\mathrm{Ni}-\mathrm{Cu}$ catalysts derived from hydrotalcite precursors. Renewable Energy. 2013;50:408-14.

[13] Ciftci A, Peng B, Jentys A, Lercher JA, Hensen EJM. Support effects in the aqueous phase reforming of glycerol over supported platinum catalysts. Applied Catalysis A: General. 2012;431432:113-9.

[14] Manfro RL, da Costa AF, Ribeiro NFP, Souza MMVM. Hydrogen production by aqueousphase reforming of glycerol over nickel catalysts supported on $\mathrm{CeO} 2$. Fuel Processing Technology. 2011;92:330-5.

[15] Byrd AJ, Pant KK, Gupta RB. Hydrogen production from glycerol by reforming in supercritical water over Ru/Al2O3 catalyst. Fuel. 2008;87:2956-60.

[16] Pairojpiriyakul T, Croiset E, Kiatkittipong W, Kiatkittipong K, Arpornwichanop A, Assabumrungrat $\mathrm{S}$. Hydrogen production from catalytic supercritical water reforming of glycerol with cobalt-based catalysts. International Journal of Hydrogen Energy. 2013;38:4368-79. 
[17] Gutiérrez Ortiz FJ, Serrera A, Galera S, Ollero P. Experimental study of the supercritical water reforming of glycerol without the addition of a catalyst. Energy. 2013;56:193-206.

[18] Dave CD, Pant KK. Renewable hydrogen generation by steam reforming of glycerol over zirconia promoted ceria supported catalyst. Renewable Energy. 2011;36:3195-202.

[19] Dieuzeide ML, lannibelli V, Jobbagy M, Amadeo N. Steam reforming of glycerol over $\mathrm{Ni} / \mathrm{Mg} / \mathrm{Y}$-Al2O3 catalysts. Effect of calcination temperatures. International Journal of Hydrogen Energy. 2012;37:14926-30.

[20] Dieuzeide ML, Jobbagy M, Amadeo N. Glycerol steam reforming over Ni/ $\mathrm{Y}-\mathrm{Al} 2 \mathrm{O} 3$ catalysts, modified with $\mathrm{Mg}$ (II). Effect of Mg (II) content. Catalysis Today. 2013;213:50-7.

[21] Araque M, Martínez T LM, Vargas JC, Centeno MA, Roger AC. Effect of the active metals on the selective $\mathrm{H} 2$ production in glycerol steam reforming. Applied Catalysis B: Environmental. 2012;125:556-66.

[22] Iriondo A, Barrio VL, Cambra JF, Arias PL, Güemez MB, Navarro RM, et al. Influence of La2O3 modified support and $\mathrm{Ni}$ and $\mathrm{Pt}$ active phases on glycerol steam reforming to produce hydrogen. Catalysis Communications. 2009;10:1275-8.

[23] Araque M, Martínez T LM, Vargas JC, Roger AC. Hydrogen production by glycerol steam reforming over CeZrCo fluorite type oxides. Catalysis Today. 2011;176:352-6.

[24] Wang $C$, Dou $B$, Chen $H$, Song $Y, X u Y, D u X$, et al. Hydrogen production from steam reforming of glycerol by $\mathrm{Ni}-\mathrm{Mg}-\mathrm{Al}$ based catalysts in a fixed-bed reactor. Chemical Engineering Journal. 2013;220:133-42.

[25] Wang X, Li S, Wang H, Liu B, Ma X. Thermodynamic analysis of glycerin steam reforming. Energy and Fuels. 2008;22:4285-91.

[26] Chen H, Ding Y, Cong NT, Dou B, Dupont V, Ghadiri M, et al. A comparative study on hydrogen production from steam-glycerol reforming: thermodynamics and experimental. Renewable Energy. 2011;36:779-88.

[27] Adhikari S, Fernando S, Haryanto A. A comparative thermodynamic and experimental analysis on hydrogen production by steam reforming of glycerin. Energy and Fuels. 2007:21:2306-10.

[28] Adhikari S, Fernando S, Gwaltney SR, Filip To SD, Mark Bricka R, Steele PH, et al. A thermodynamic analysis of hydrogen production by steam reforming of glycerol. International Journal of Hydrogen Energy. 2007;32:2875-80.

[29] Hajjaji N, Chahbani A, Khila Z, Pons M-N. A comprehensive energy-exergy-based assessment and parametric study of a hydrogen production process using steam glycerol reforming. Energy. 2014;64:473-83.

[30] Dieuzeide ML, Amadeo N. Thermodynamic analysis of Glycerol steam reforming. Chemical Engineering and Technology. 2010;33:89-96.

[31] Rossi CCRS, Alonso CG, Antunes OAC, Guirardello R, Cardozo-Filho L. Thermodynamic analysis of steam reforming of ethanol and glycerine for hydrogen production. International Journal of Hydrogen Energy. 2009;34:323-32.

[32] Fishtik I, Alexander A, Datta R, Geana D. Thermodynamic analysis of hydrogen production by steam reforming of ethanol via response reactions. International Journal of Hydrogen Energy. 2000;25:31-45.

[33] Mas V, Kipreos R, Amadeo N, Laborde M. Thermodynamic analysis of ethanol/water system with the stoichiometric method. International Journal of Hydrogen Energy. 2006;31:21-8. 
[34] Authayanun S, Arpornwichanop A, Paengjuntuek W, Assabumrungrat S. Thermodynamic study of hydrogen production from crude glycerol autothermal reforming for fuel cell applications. International Journal of Hydrogen Energy. 2010;35:6617-23.

[35] Gutiérrez Ortiz FJ, Ollero P, Serrera A. Thermodynamic analysis of the autothermal reforming of glycerol using supercritical water. International Journal of Hydrogen Energy. 2011;36:12186-99.

[36] Gutiérrez Ortiz FJ, Ollero P, Serrera A, Sanz A. Thermodynamic study of the supercritical water reforming of glycerol. International Journal of Hydrogen Energy. 2011;36:8994-9013.

[37] Wang H, Wang X, Li M, Li S, Wang S, Ma X. Thermodynamic analysis of hydrogen production from glycerol autothermal reforming. International Journal of Hydrogen Energy. 2009;34:568390.

[38] Cheng CK, Foo SY, Adesina AA. Thermodynamic analysis of glycerol-steam reforming in the presence of $\mathrm{CO} 2$ or $\mathrm{H} 2$ as carbon gasifying agent. International Journal of Hydrogen Energy. 2012;37:10101-10.

[39] Authayanun S, Arpornwichanop A, Patcharavorachot $Y$, Wiyaratn W, Assabumrungrat S. Hydrogen production from glycerol steam reforming for low- and high-temperature PEMFCs. International Journal of Hydrogen Energy. 2011;36:267-75.

[40] Olajire AA. Valorization of greenhouse carbon dioxide emissions into value-added products by catalytic processes. Journal of CO2 Utilization. 2013;3-4:74-92.

[41] Li Y, Wang W, Chen B, Cao Y. Thermodynamic analysis of hydrogen production via glycerol steam reforming with $\mathrm{CO} 2$ adsorption. International Journal of Hydrogen Energy. 2010;35:776877.

[42] Chen H, Zhang T, Dou B, Dupont V, Williams P, Ghadiri M, et al. Thermodynamic analyses of adsorption-enhanced steam reforming of glycerol for hydrogen production. International Journal of Hydrogen Energy. 2009;34:7208-22.

[43] Lima da Silva A, Müller IL. Hydrogen production by sorption enhanced steam reforming of oxygenated hydrocarbons (ethanol, glycerol, n-butanol and methanol): Thermodynamic modelling. International Journal of Hydrogen Energy. 2011;36:2057-75.

[44] He L, Parra JMS, Blekkan EA, Chen D. Towards efficient hydrogen production from glycerol by sorption enhanced steam reforming. Energy and Environmental Science. 2010;3:1046-56.

[45] Wang X, Wang N, Li M, Li S, Wang S, Ma X. Hydrogen production by glycerol steam reforming with in situ hydrogen separation: A thermodynamic investigation. International Journal of Hydrogen Energy. 2010;35:10252-6.

[46] Lin Y-C. Catalytic valorization of glycerol to hydrogen and syngas. International Journal of Hydrogen Energy. 2013;38:2678-700.

[47] Adhikari S, Fernando SD, Haryanto A. Hydrogen production from glycerin by steam reforming over nickel catalysts. Renewable Energy. 2008;33:1097-100.

[48] Adhikari S, Fernando SD, To SDF, Bricka RM, Steele PH, Haryanto A. Conversion of glycerol to hydrogen via a steam reforming process over nickel catalysts. Energy and Fuels. 2008;22:1220-6.

[49] Sánchez EA, D'Angelo MA, Comelli RA. Hydrogen production from glycerol on Ni/Al2O3 catalyst. International Journal of Hydrogen Energy. 2010;35:5902-7. 
[50] Pant KK, Jain R, Jain S. Renewable hydrogen production by steam reforming of glycerol over $\mathrm{Ni} / \mathrm{CeO} 2$ catalyst prepared by precipitation deposition method. Korean Journal of Chemical Engineering. 2011;28:1859-66.

[51] Nichele V, Signoretto M, Menegazzo F, Gallo A, Dal Santo V, Cruciani G, et al. Glycerol steam reforming for hydrogen production: Design of $\mathrm{Ni}$ supported catalysts. Applied Catalysis B: Environmental. 2012;111-112:225-32.

[52] Patel S, Pant KK. Production of hydrogen with low carbon monoxide formation via catalytic steam reforming of methanol. Journal of Fuel Cell Science and Technology. 2006;3:369-74.

[53] Iriondo A, Barrio VL, Cambra JF, Arias PL, Guemez MB, Sanchez-Sanchez MC, et al. Glycerol steam reforming over $\mathrm{Ni}$ catalysts supported on ceria and ceria-promoted alumina. International Journal of Hydrogen Energy. 2010;35:11622-33.

[54] Cui Y, Galvita V, Rihko-Struckmann L, Lorenz H, Sundmacher K. Steam reforming of glycerol: The experimental activity of $\mathrm{La} 1-\mathrm{xCexNiO3}$ catalyst in comparison to the thermodynamic reaction equilibrium. Applied Catalysis B: Environmental. 2009;90:29-37.

[55] Franchini CA, Aranzaez W, Duarte de Farias AM, Pecchi G, Fraga MA. Ce-substituted LaNiO3 mixed oxides as catalyst precursors for glycerol steam reforming. Applied Catalysis B: Environmental. 2014;147:193-202.

[56] Adhikari S, Fernando S, Haryanto A. Production of hydrogen by steam reforming of glycerin over alumina-supported metal catalysts. Catalysis Today. 2007;129:355-64.

[57] Matas Güell B, Babich I, Nichols KP, Gardeniers JGE, Lefferts L, Seshan K. Design of a stable steam reforming catalyst-A promising route to sustainable hydrogen from biomass oxygenates. Applied Catalysis B: Environmental. 2009;90:38-44.

[58] Hagh BF. Optimization of autothermal reactor for maximum hydrogen production. International Journal of Hydrogen Energy. 2003;28:1369-77.

[59] Slinn M, Kendall K, Mallon C, Andrews J. Steam reforming of biodiesel by-product to make renewable hydrogen. Bioresource Technology. 2008;99:5851-8.

[60] Kim SM, Woo SI. Sustainable production of syngas from biomass-derived glycerol by steam reforming over highly stable Ni/SiC. ChemSusChem. 2012;5:1513-22.

[61] Wen G, Xu Y, Ma H, Xu Z, Tian Z. Production of hydrogen by aqueous-phase reforming of glycerol. International Journal of Hydrogen Energy. 2008;33:6657-66.

[62] Sanchez EA, Comelli RA. Hydrogen by glycerol steam reforming on a nickel-alumina catalyst: Deactivation processes and regeneration. International Journal of Hydrogen Energy. 2012;37:14740-6.

[63] Ni M, Leung DYC, Leung MKH. A review on reforming bio-ethanol for hydrogen production. International Journal of Hydrogen Energy. 2007;32:3238-47.

[64] Seo JG, Youn MH, Park S, Chung JS, Song IK. Hydrogen production by steam reforming of liquefied natural gas (LNG) over Ni/Al2O3-ZrO2 xerogel catalysts: Effect of calcination temperature of Al2O3-ZrO2 xerogel supports. International Journal of Hydrogen Energy. 2009;34:3755-63.

[65] Iriondo A, Cambra JF, Güemez MB, Barrio VL, Requies J, Sánchez-Sánchez MC, et al. Effect of $\mathrm{ZrO} 2$ addition on $\mathrm{Ni} / \mathrm{Al} 2 \mathrm{O} 3$ catalyst to produce $\mathrm{H} 2$ from glycerol. International Journal of Hydrogen Energy. 2012;37:7084-93. 
[66] Huang Z-Y, Xu C-H, Meng J, Zheng C-F, Xiao H-W, Chen J, et al. Glycerol steam reforming to syngas over Ni-based catalysts on commercial Linde-type $5 \mathrm{~A}$ zeolite modified by metal oxides. Journal of Environmental Chemical Engineering. in press.

[67] Iriondo A, Barrio VL, Cambra JF, Arias PL, Güemez MB, Navarro RM, et al. Hydrogen production from glycerol over nickel catalysts supported on Al2O3 modified by Mg, Zr, Ce or La. Topics in Catalysis. 2008;49:46-58.

[68] Buffoni IN, Pompeo F, Santori GF, Nichio NN. Nickel catalysts applied in steam reforming of glycerol for hydrogen production. Catalysis Communications. 2009;10:1656-60.

[69] Kitamura S, Su-Enaga T, Ikenaga NO, Miyake T, Suzuki T. Steam reforming of glycerin using Ni-based catalysts loaded on CaO-ZrO 2 solid solution. Catalysis Letters. 2011;141:895-905.

[70] Damyanova S, Bueno JMC. Effect of $\mathrm{CeO} 2$ loading on the surface and catalytic behaviors of CeO2-Al2O3-supported Pt catalysts. Applied Catalysis A: General. 2003;253:135-50.

[71] Takanabe K, Aika K-i, Seshan K, Lefferts L. Sustainable hydrogen from bio-oil-Steam reforming of acetic acid as a model oxygenate. Journal of Catalysis. 2004;227:101-8.

[72] Seo JG, Youn MH, Song IK. Hydrogen production by steam reforming of LNG over Ni/Al2O3ZrO2 catalysts: Effect of Al2O3-ZrO2 supports prepared by a grafting method. Journal of Molecular Catalysis A: Chemical. 2007;268:9-14.

[73] Seo JG, Youn MH, Jung JC, Cho KM, Park S, Song IK. Preparation of Ni/Al2O3-ZrO2 catalysts and their application to hydrogen production by steam reforming of LNG: Effect of ZrO2 content grafted on Al2O3. Catalysis Today. 2008;138:130-4.

[74] Mawdsley JR, Krause TR. Rare earth-first-row transition metal perovskites as catalysts for the autothermal reforming of hydrocarbon fuels to generate hydrogen. Applied Catalysis A: General. 2008;334:311-20.

[75] Liguras DK, Kondarides DI, Verykios XE. Production of hydrogen for fuel cells by steam reforming of ethanol over supported noble metal catalysts. Applied Catalysis B: Environmental. 2003;43:345-54.

[76] Thyssen VV, Maia TA, Assaf EM. Ni supported on La2O3-SiO2 used to catalyze glycerol steam reforming. Fuel. 2013;105:358-63.

[77] Rostrup-Nielsen JR, Sehested J, Nørskov JK. Hydrogen and synthesis gas by steam- and C02 reforming. 2002. p. 65-139.

[78] Basagiannis AC, Verykios XE. Steam reforming of the aqueous fraction of bio-oil over structured Ru/MgO/Al2O3 catalysts. Catalysis Today. 2007;127:256-64.

[79] Huang ZY, Xu CH, Liu CQ, Xiao HW, Chen J, Zhang YX, et al. Glycerol steam reforming over $\mathrm{Ni} / \mathrm{Y}$-Al2O3 catalysts modified by metal oxides. Korean Journal of Chemical Engineering. 2013;30:587-92.

[80] Suelves I, Lázaro MJ, Moliner R, Echegoyen Y, Palacios JM. Characterization of NiAl and NiCuAl catalysts prepared by different methods for hydrogen production by thermo catalytic decomposition of methane. Catalysis Today. 2006;116:271-80.

[81] Maluf SS, Assaf EM. Ni catalysts with Mo promoter for methane steam reforming. Fuel. 2009;88:1547-53

[82] Youn MH, Seo JG, Kim P, Song IK. Role and effect of molybdenum on the performance of Ni$\mathrm{Mo} / \mathrm{Y}-\mathrm{Al} 2 \mathrm{O} 3$ catalysts in the hydrogen production by auto-thermal reforming of ethanol. Journal of Molecular Catalysis A: Chemical. 2007;261:276-81. 
[83] Huang T, Huang W, Huang J, Ji P. Methane reforming reaction with carbon dioxide over SBA15 supported Ni-Mo bimetallic catalysts. Fuel Processing Technology. 2011;92:1868-75.

[84] Wu G, Li S, Zhang C, Wang T, Gong J. Glycerol steam reforming over perovskite-derived nickel-based catalysts. Applied Catalysis B: Environmental. 2014;144:277-85.

[85] Hakim L, Yaakob Z, Ismail M, Daud WRW, Sari R. Hydrogen production by steam reforming of glycerol over Ni/Ce/Cu hydroxyapatite-supported catalysts. Chemical Papers. 2013;67:70312.

[86] Profeti LPR, Ticianelli EA, Assaf EM. Production of hydrogen via steam reforming of biofuels on $\mathrm{Ni} / \mathrm{CeO} 2-\mathrm{Al} 2 \mathrm{O} 3$ catalysts promoted by noble metals. International Journal of Hydrogen Energy. 2009;34:5049-60.

[87] Zhou CH, Zhao H, Tong DS, Wu LM, Yu WH. Recent advances in catalytic conversion of glycerol. Catalysis Reviews - Science and Engineering. 2013;55:369-453.

[88] Simonetti DA, Soares RR, Dumesic JA. Glycerol as a source for fuels and chemicals by lowtemperature catalytic processing. 2006.

[89] Sutar PN, Vaidya PD, Rodrigues AE. Glycerol-reforming kinetics using a Pt/C catalyst. Chemical Engineering and Technology. 2010;33:1645-9.

[90] Simonetti DA, Kunkes EL, Dumesic JA. Gas-phase conversion of glycerol to synthesis gas over carbon-supported platinum and platinum-rhenium catalysts. Journal of Catalysis. 2007;247:298306.

[91] Pompeo F, Santori GF, Nichio NN. Hydrogen production by glycerol steam reforming with $\mathrm{Pt} / \mathrm{SiO} 2$ and Ni/SiO2 catalysts. Catalysis Today. 2011;172:183-8.

[92] Montini T, Singh R, Das P, Lorenzut B, Bertero N, Riello P, et al. Renewable H2 from glycerol steam reforming: Effect of $\mathrm{La} 2 \mathrm{O} 3$ and $\mathrm{CeO} 2$ addition to Pt/Al2O3 catalysts. ChemSusChem. 2010;3:619-28.

[93] Kunkes EL, Soares RR, Simonetti DA, Dumesic JA. An integrated catalytic approach for the production of hydrogen by glycerol reforming coupled with water-gas shift. Applied Catalysis B: Environmental. 2009;90:693-8.

[94] Roh H-S, Potdar HS, Jeong D-W, Kim K-S, Shim J-O, Jang W-J, et al. Synthesis of highly active nano-sized (1\&\#xa0;wt.\% Pt/CeO2) catalyst for water gas shift reaction in medium temperature application. Catalysis Today. 2012;185:113-8.

[95] González ID, Navarro RM, Wen W, Marinkovic N, Rodriguéz JA, Rosa F, et al. A comparative study of the water gas shift reaction over platinum catalysts supported on $\mathrm{CeO} 2, \mathrm{TiO} 2$ and $\mathrm{Ce}-$ modified TiO2. Catalysis Today. 2010;149:372-9.

[96] Jeong D-W, Potdar HS, Shim J-O, Jang W-J, Roh H-S. H2 production from a single stage water-gas shift reaction over $\mathrm{Pt} / \mathrm{CeO} 2, \mathrm{Pt} / \mathrm{ZrO} 2$, and $\mathrm{Pt} / \mathrm{Ce}(1-\mathrm{x}) \mathrm{Zr}(\mathrm{x}) \mathrm{O} 2$ catalysts. International Journal of Hydrogen Energy. 2013;38:4502-7.

[97] Pompeo F, Santori G, Nichio NN. Hydrogen and/or syngas from steam reforming of glycerol. Study of platinum catalysts. International Journal of Hydrogen Energy. 2010;35:8912-20.

[98] Gervasini A, Fenyvesi J, Auroux A. Study of the acidic character of modified metal oxide surfaces using the test of isopropanol decomposition. Catalysis Letters. 1997;43:219-28.

[99] Zhang XH, Yan FW, Guo CY, Yuan GQ. Steam reforming of glycerol over Pt-MCM-41 synthesized in a one-step process. Russian Journal of Physical Chemistry A. 2012;86:1957-61.

[100] Greeley J, Mavrikakis M. Alloy catalysts designed from first principles. Nature Materials. 2004;3:810-5. 
[101] Ishikawa Y, Liao M-S, Cabrera CR. Energetics of H2O dissociation and COads+OHads reaction on a series of Pt-M mixed metal clusters: a relativistic density-functional study. Surface Science. 2002;513:98-110.

[102] Lehnert K, Claus P. Influence of Pt particle size and support type on the aqueous-phase reforming of glycerol. Catalysis Communications. 2008;9:2543-6.

[103] Frusteri F, Freni S, Spadaro L, Chiodo V, Bonura G, Donato S, et al. H2 production for MC fuel cell by steam reforming of ethanol over $\mathrm{MgO}$ supported $\mathrm{Pd}, \mathrm{Rh}, \mathrm{Ni}$ and Co catalysts. Catalysis Communications. 2004;5:611-5.

[104] Llorca J, Homs Ns, Sales J, Fierro J-LG, Ramírez de la Piscina P. Effect of sodium addition on the performance of $\mathrm{Co}-\mathrm{ZnO}$-based catalysts for hydrogen production from bioethanol. Journal of Catalysis. 2004;222:470-80.

[105] Batista MS, Santos RKS, Assaf EM, Assaf JM, Ticianelli EA. High efficiency steam reforming of ethanol by cobalt-based catalysts. Journal of Power Sources. 2004;134:27-32.

[106] Zhang B, Tang X, Li Y, Xu Y, Shen W. Hydrogen production from steam reforming of ethanol and glycerol over ceria-supported metal catalysts. International Journal of Hydrogen Energy. 2007;32:2367-73.

[107] Cheng CK, Foo SY, Adesina AA. H2-rich synthesis gas production over Co/Al2O3 catalyst via glycerol steam reforming. Catalysis Communications. 2010;12:292-8.

[108] Cheng CK, Foo SY, Adesina AA. Glycerol Steam Reforming over Bimetallic Co-Ni/Al2O3. Industrial \& Engineering Chemistry Research. 2010;49:10804-17.

[109] Martínez T LM, Araque M, Vargas JC, Roger AC. Effect of Ce/Zr ratio in CeZr-CoRh catalysts on the hydrogen production by glycerol steam reforming. Applied Catalysis B: Environmental. 2013;132-133:499-510.

[110] Opoku-Gyamfi K, Adesina AA. Forced composition cycling of a novel thermally selfsustaining fluidised-bed reactor for methane reforming. Chemical Engineering Science. 1999;54:2575-83.

[111] Ambroise E, Courson C, Roger AC, Kiennemann A, Blanchard G, Rousseau S, et al. Exhaust gas recirculation for on-board hydrogen production by isooctane reforming: Comparison of performances of metal/ceria-zirconia based catalysts prepared through pseudo sol-gel or impregnation methods. Catalysis Today. 2010;154:133-41.

[112] Vargas JC, Libs S, Roger AC, Kiennemann A. Study of Ce-Zr-Co fluorite-type oxide as catalysts for hydrogen production by steam reforming of bioethanol. Catalysis Today. 2005;107108:417-25.

[113] Romero-Sarria F, Vargas JC, Roger AC, Kiennemann A. Hydrogen production by steam reforming of ethanol. Study of mixed oxide catalysts Ce2Zr1.5Me0.5O8: Comparison of Ni/Co and effect of Rh. Catalysis Today. 2008;133-135:149-53.

[114] Sundari R, Vaidya PD. Reaction Kinetics of Glycerol Steam Reforming Using a Ru/Al2O3 Catalyst. Energy \& Fuels. 2012;26:4195-204.

[115] Piscina PRDL, Homs N. Use of biofuels to produce hydrogen (reformation processes). Chemical Society Reviews. 2008;37:2459-67.

[116] Soria MA, Mateos-Pedrero C, Rodríguez-Ramos I, Guerrero-Ruiz A. Catalytic steam reforming of methane under conditions of applicability with Pd membranes over supported Ru catalysts. Catalysis Today. 2011;171:126-31. 
[117] Hirai T, Ikenaga NO, Miyake T, Suzuki T. Production of hydrogen by steam reforming of glycerin on ruthenium catalyst. Energy and Fuels. 2005;19:1761-2.

[118] Nakagawa K, Hideshima S, Akamatsu N, Matsui NO, Ikenaga NO, Suzuki T. CO2 Reforming of Methane over Ru-Loaded Lanthanoid Oxide Catalysts. 2002. p. 205-23.

[119] Kim J, Lee D. Glycerol steam reforming on supported Ru-based catalysts for hydrogen production for fuel cells. International Journal of Hydrogen Energy. 2013;38:11853-62.

[120] Gallo A, Pirovano C, Marelli M, Psaro R, Dal Santo V. Hydrogen Production by Glycerol Steam Reforming with Ru-based Catalysts: A Study on Sn Doping. Chemical Vapor Deposition. 2010;16:305-10.

[121] Gallo A, Pirovano C, Ferrini P, Marelli M, Psaro R, Santangelo S, et al. Influence of reaction parameters on the activity of ruthenium based catalysts for glycerol steam reforming. Applied Catalysis B: Environmental. 2012;121-122:40-9.

[122] Dou B, Dupont V, Rickett G, Blakeman N, Williams PT, Chen H, et al. Hydrogen production by sorption-enhanced steam reforming of glycerol. Bioresource Technology. 2009;100:3540-7.

[123] Rass-Hansen J, Christensen CH, Sehested J, Helveg S, Rostrup-Nielsen JR, Dahl S. Renewable hydrogen: Carbon formation on $\mathrm{Ni}$ and Ru catalysts during ethanol steam-reforming. Green Chemistry. 2007;9:1016-21.

[124] Basagiannis AC, Verykios XE. Influence of the carrier on steam reforming of acetic acid over Ru-based catalysts. Applied Catalysis B: Environmental. 2008;82:77-88.

[125] Basile F, Fornasari G, Rosetti V, Trifirò F, Vaccari A. Effect of the Mg/Al ratio of the hydrotalcite-type precursor on the dispersion and activity of Rh and Ru catalysts for the partial oxidation of methane. Catalysis Today. 2004;91-92:293-7.

[126] Park SY, Kim JH, Moon DJ, Park NC, Kim YC. Autothermal reforming of propane over Nibased hydrotalcite catalysts. Journal of Nanoscience and Nanotechnology. 2010;10:3175-9.

[127] Lee HJ, Lim YS, Park NC, Kim YC. Catalytic autothermal reforming of propane over the noble metal-doped hydrotalcite-type catalysts. Chemical Engineering Journal. 2009;146:295-301.

[128] Chiodo V, Freni S, Galvagno A, Mondello N, Frusteri F. Catalytic features of Rh and Ni supported catalysts in the steam reforming of glycerol to produce hydrogen. Applied Catalysis A: General. 2010;381:1-7.

[129] Palmeri N, Chiodo V, Freni S, Frusteri F, Bart JCJ, Cavallaro S. Hydrogen from oxygenated solvents by steam reforming on $\mathrm{Ni} / \mathrm{Al} 2 \mathrm{O} 3$ catalyst. International Journal of Hydrogen Energy. 2008;33:6627-34.

[130] Cavallaro S, Chiodo V, Freni S, Mondello N, Frusteri F. Performance of Rh/Al2O3 catalyst in the steam reforming of ethanol: H2 production for MCFC. Applied Catalysis A: General. 2003;249:119-28

[131] Frusteri F, Spadaro L, Arena F, Chuvilin A. TEM evidence for factors affecting the genesis of carbon species on bare and $\mathrm{K}$-promoted $\mathrm{Ni} / \mathrm{MgO}$ catalysts during the dry reforming of methane. Carbon. 2002;40:1063-70.

[132] Bartholomew CH. CARBON DEPOSITION IN STEAM REFORMING AND METHANATION. Catalysis reviews. 1982;24:67-112.

[133] Ebshish A, Yaakob Z, Taufiq-Yap YH, Bshish A, Shaibani A. Catalytic Steam Reforming of Glycerol Over Cerium and Palladium-Based Catalysts for Hydrogen Production. Journal of Fuel Cell Science and Technology. 2013;10:021003-. 
[134] Cheng CK, Foo SY, Adesina AA. Steam reforming of glycerol over Ni/Al2O3 catalyst. Catalysis Today. 2011;178:25-33.

[135] Adhikari S, Fernando SD, Haryanto A. Kinetics and Reactor Modeling of Hydrogen Production from Glycerol via Steam Reforming Process over Ni/CeO2 Catalysts. Chemical Engineering \& Technology. 2009;32:541-7.

[136] Cheng CK, Foo SY, Adesina AA. Carbon deposition on bimetallic Co-Ni/Al2O3 catalyst during steam reforming of glycerol. Catalysis Today. 2011;164:268-74.

[137] Sundaram KM, Froment GF. Kinetics of coke deposition in the thermal cracking of propane. Chemical Engineering Science. 1979;34:635-44.

[138] Van Damme PS, Narayanan S, Froment GF. THERMAL CRACKING OF PROPANE AND PROPANE-PROPYLENE MIXTURES: PILOT PLANT VERSUS INDUSTRIAL DATA. AIChE Journal. 1975;21:1065-73.

[139] Dou B, Wang C, Chen H, Song Y, Xie B. Continuous sorption-enhanced steam reforming of glycerol to high-purity hydrogen production. International Journal of Hydrogen Energy. 2013;38:11902-9.

[140] Hanif A, Dasgupta S, Divekar S, Arya A, Garg MO, Nanoti A. A study on high temperature CO2 capture by improved hydrotalcite sorbents. Chemical Engineering Journal. 2014;236:91-9.

[141] Maroño M, Torreiro Y, Gutierrez L. Influence of steam partial pressures in the CO2 capture capacity of K-doped hydrotalcite-based sorbents for their application to SEWGS processes. International Journal of Greenhouse Gas Control. 2013;14:183-92.

[142] Martunus, Helwani Z, Wiheeb AD, Kim J, Othman MR. Improved carbon dioxide capture using metal reinforced hydrotalcite under wet conditions. International Journal of Greenhouse Gas Control. 2012;7:127-36.

[143] Aschenbrenner O, McGuire P, Alsamaq S, Wang J, Supasitmongkol S, Al-Duri B, et al. Adsorption of carbon dioxide on hydrotalcite-like compounds of different compositions. Chemical Engineering Research and Design. 2011;89:1711-21.

[144] Wang Q, Tay HH, Guo Z, Chen L, Liu Y, Chang J, et al. Morphology and composition controllable synthesis of $\mathrm{Mg}-\mathrm{Al}-\mathrm{CO} 3$ hydrotalcites by tuning the synthesis $\mathrm{pH}$ and the $\mathrm{CO} 2$ capture capacity. Applied Clay Science. 2012;55:18-26.

[145] Wang Y, Zhu Y, Wu S. A new nano CaO-based CO2 adsorbent prepared using an adsorption phase technique. Chemical Engineering Journal. 2013;218:39-45.

[146] Sanchez-Jimenez PE, Perez-Maqueda LA, Valverde JM. Nanosilica supported CaO: A regenerable and mechanically hard $\mathrm{CO} 2$ sorbent at Ca-looping conditions. Applied Energy. 2014;118:92-9.

[147] Zhang X, Li Z, Peng Y, Su W, Sun X, Li J. Investigation on a novel CaO-Y2O3 sorbent for efficient CO2 mitigation. Chemical Engineering Journal. 2014;243:297-304.

[148] Nieto-Sanchez AJ, Olivares-Marin M, Garcia S, Pevida C, Cuerda-Correa EM. Influence of the operation conditions on $\mathrm{CO} 2$ capture by $\mathrm{CaO}$-derived sorbents prepared from synthetic CaCO3. Chemosphere. 2013;93:2148-58.

[149] Akgsornpeak A, Witoon T, Mungcharoen T, Limtrakul J. Development of synthetic CaO sorbents via CTAB-assisted sol-gel method for $\mathrm{CO} 2$ capture at high temperature. Chemical Engineering Journal. 2014;237:189-98.

[150] Wang S, An C, Zhang Q-H. Syntheses and structures of lithium zirconates for hightemperature CO2 absorption. Journal of Materials Chemistry A. 2013;1:3540-50. 
[151] Duan Y. Structural and electronic properties of Li8ZrO6 and its CO2 capture capabilities: an ab initio thermodynamic approach. Physical Chemistry Chemical Physics. 2013;15:9752-60.

[152] Xiao Q, Tang X, Liu Y, Zhong Y, Zhu W. Citrate route to prepare K-doped Li2ZrO3 sorbents with excellent CO2 capture properties. Chemical Engineering Journal. 2011;174:231-5.

[153] Halabi MH, de Croon MHJM, van der Schaaf J, Cobden PD, Schouten JC. Reactor modeling of sorption-enhanced autothermal reforming of methane. Part I: Performance study of hydrotalcite and lithium zirconate-based processes. Chemical Engineering Journal. 2011;168:872-82.

[154] Iwan A, Stephenson H, Ketchie WC, Lapkin AA. High temperature sequestration of CO2 using lithium zirconates. Chemical Engineering Journal. 2009;146:249-58.

[155] Mizunuma M, Tsuda M, Maruo Y, Nakagaki T. CO2 Capture System Using Lithium Silicate for Distributed Power Supply. Energy Procedia. 2013;37:1194-201.

[156] Seggiani M, Puccini M, Vitolo S. Alkali promoted lithium orthosilicate for CO2 capture at high temperature and low concentration. International Journal of Greenhouse Gas Control. 2013;17:25-31.

[157] Chowdhury MBI, Quddus MR, deLasa HI. CO2 capture with a novel solid fluidizable sorbent: Thermodynamics and Temperature Programmed Carbonation-Decarbonation. Chemical Engineering Journal. 2013;232:139-48.

[158] Shan S, Jia Q, Jiang L, Li Q, Wang Y, Peng J. Novel Li4SiO4-based sorbents from diatomite for high temperature CO2 capture. Ceramics International. 2013;39:5437-41.

[159] Duan Y, Pfeiffer H, Li B, Romero-Ibarra IC, Sorescu DC, Luebke DR, et al. CO2 capture properties of lithium silicates with different ratios of Li2O/SiO2: an ab initio thermodynamic and experimental approach. Physical Chemistry Chemical Physics. 2013;15:13538-58.

[160] Yong Z, Rodrigues ArE. Hydrotalcite-like compounds as adsorbents for carbon dioxide. Energy Conversion and Management. 2002;43:1865-76.

[161] Yong Z, Mata V, Rodrigues ArE. Adsorption of carbon dioxide at high temperature-a review. Separation and Purification Technology. 2002;26:195-205.

[162] Yong Z, Mata V, Rodrigues A. Adsorption of Carbon Dioxide on Chemically Modified High Surface Area Carbon-Based Adsorbents at High Temperature. Adsorption. 2001;7:41-50.

[163] Gupta H, Fan L-S. Carbonation-Calcination Cycle Using High Reactivity Calcium Oxide for Carbon Dioxide Separation from Flue Gas. Industrial \& Engineering Chemistry Research. 2002;41:4035-42.

[164] L. G. Oliveira E. Sorption enhanced steam methane reforming process for continuous production of hydrogen in pressure swing adsorptive reactors: University of Porto; 2009.

[165] Carlos VM, Raquel T, Vicente R, Miguel AV, Alexandre FPF, Alírio ER, et al. High Temperature $\mathrm{CO} 2$ Sorption with Gallium-Substituted and Promoted Hydrotalcites. Separation and Purification Technology. in press.

[166] Lu H, Reddy EP, Smirniotis PG. Calcium oxide based sorbents for capture of carbon dioxide at high temperatures. Industrial and Engineering Chemistry Research. 2006;45:3944-9.

[167] Wang L, Li D, Watanabe H, Tamura M, Nakagawa Y, Tomishige K. Catalytic performance and characterization of $\mathrm{Co} / \mathrm{Mg} / \mathrm{Al}$ catalysts prepared from hydrotalcite-like precursors for the steam gasification of biomass. Applied Catalysis B: Environmental. 2014;150-151:82-92. 
[168] Wang Q, Wu Z, Tay HH, Chen L, Liu Y, Chang J, et al. High temperature adsorption of CO2 on Mg-Al hydrotalcite: Effect of the charge compensating anions and the synthesis $\mathrm{pH}$. Catalysis Today. 2011;164:198-203.

[169] Fermoso J, He L, Chen D. Production of high purity hydrogen by sorption enhanced steam reforming of crude glycerol. International Journal of Hydrogen Energy. 2012;37:14047-54.

[170] Dou B, Rickett GL, Dupont V, Williams PT, Chen H, Ding Y, et al. Steam reforming of crude glycerol with in situ CO2 sorption. Bioresource Technology. 2010;101:2436-42.

[171] Chen H, Ding Y, Cong NT, Dou B, Dupont V, Ghadiri M, et al. Progress in low temperature hydrogen production with simultaneous $\mathrm{CO} 2$ abatement. Chemical Engineering Research and Design. 2011;89:1774-82.

[172] Wang X, Li M, Li S, Wang H, Wang S, Ma X. Hydrogen production by glycerol steam reforming with/without calcium oxide sorbent: A comparative study of thermodynamic and experimental work. Fuel Processing Technology. 2010;91:1812-8.

[173] Terminology for membranes and membrane processes (IUPAC Recommendation 1996). Journal of Membrane Science. 1996;120:149-59.

[174] Haag S, Burgard M, Ernst B. Beneficial effects of the use of a nickel membrane reactor for the dry reforming of methane: Comparison with thermodynamic predictions. Journal of Catalysis. 2007;252:190-204.

[175] Gallucci F, Fernandez E, Corengia P, van Sint Annaland M. Recent advances on membranes and membrane reactors for hydrogen production. Chemical Engineering Science. 2013;92:4066.

[176] Adhikari S, Fernando S. Hydrogen membrane separation techniques. Industrial and Engineering Chemistry Research. 2006;45:875-81.

[177] Miguel CV, Mendes A, Tosti S, Madeira LM. Effect of $\mathrm{CO}$ and $\mathrm{CO} 2$ on $\mathrm{H} 2$ permeation through finger-like $\mathrm{Pd}-\mathrm{Ag}$ membranes. International Journal of Hydrogen Energy. 2012;37:12680-7

[178] Tosti S, Basile A, Bettinali L, Borgognoni F, Chiaravalloti F, Gallucci F. Long-term tests of $\mathrm{Pd}-\mathrm{Ag}$ thin wall permeator tube. Journal of Membrane Science. 2006;284:393-7.

[179] Mendes D, Mendes A, Madeira LM, Iulianelli A, Sousa JM, Basile A. The water-gas shift reaction: From conventional catalytic systems to $\mathrm{Pd}$-based membrane reactors- $\mathrm{A}$ review. AsiaPacific Journal of Chemical Engineering. 2010;5:111-37.

[180] Mendes D, Chibante V, Zheng JM, Tosti S, Borgognoni F, Mendes A, et al. Enhancing the production of hydrogen via water-gas shift reaction using Pd-based membrane reactors. International Journal of Hydrogen Energy. 2010;35:12596-608.

[181] Santucci A, Borgognoni F, Vadrucci M, Tosti S. Testing of dense Pd-Ag tubes: Effect of pressure and membrane thickness on the hydrogen permeability. Journal of Membrane Science. 2013;444:378-83.

[182] Nayebossadri S, Speight J, Book D. Effects of low Ag additions on the hydrogen permeability of $\mathrm{Pd}-\mathrm{Cu}-\mathrm{Ag}$ hydrogen separation membranes. Journal of Membrane Science. 2014;451:216-25.

[183] Lewis AE, Kershner DC, Paglieri SN, Slepicka MJ, Way JD. Pd-Pt/YSZ composite membranes for hydrogen separation from synthetic water-gas shift streams. Journal of Membrane Science. 2013;437:257-64. 
[184] Wei L, Yu J, Huang Y. Silver coating on porous stainless steel substrate and preparation of $\mathrm{H} 2$-permeable palladium membranes. International Journal of Hydrogen Energy. 2013;38:10833-8.

[185] Wei L, Yu J, Hu X, Huang Y. Fabrication of H2-permeable palladium membranes based on pencil-coated porous stainless steel substrate. International Journal of Hydrogen Energy. 2012;37:13007-12.

[186] Zhang D, Zhou S, Fan Y, Xu N, He Y. Preparation of dense Pd composite membranes on porous Ti-Al alloy supports by electroless plating. Journal of Membrane Science. 2012;387388:24-9.

[187] Braun F, Tarditi AM, Miller JB, Cornaglia LM. Pd-based binary and ternary alloy membranes: Morphological and perm-selective characterization in the presence of $\mathrm{H} 2 \mathrm{~S}$. Journal of Membrane Science. 2014;450:299-307.

[188] Basile A, Gallucci F, Iulianelli A, Tereschenko GF, Ermilova MM, Orekhova NV. Ti-Ni-Pd dense membranes-The effect of the gas mixtures on the hydrogen permeation. Journal of Membrane Science. 2008;310:44-50.

[189] Peters TA, Kaleta T, Stange M, Bredesen R. Development of thin binary and ternary Pdbased alloy membranes for use in hydrogen production. Journal of Membrane Science. 2011;383:124-34.

[190] Chang ACC, Lin W-H, Lin K-H, Hsiao C-H, Chen H-H, Chang H-F. Reforming of glycerol for producing hydrogen in a $\mathrm{Pd} / \mathrm{Ag}$ membrane reactor. International Journal of Hydrogen Energy. 2012;37:13110-7.

[191] Iulianelli A, Longo T, Liguori S, Basile A. Production of hydrogen via glycerol steam reforming in a Pd-Ag membrane reactor over $\mathrm{Co}-\mathrm{Al} 2 \mathrm{O} 3$ catalyst. Asia-Pacific Journal of Chemical Engineering. 2010;5:138-45.

[192] Lin K-H, Lin W-H, Hsiao C-H, Chang H-F, Chang ACC. Hydrogen production in steam reforming of glycerol by conventional and membrane reactors. International Journal of Hydrogen Energy. 2012;37:13770-6.

[193] Iulianelli A, Seelam PK, Liguori S, Longo T, Keiski R, Calabrò V, et al. Hydrogen production for PEM fuel cell by gas phase reforming of glycerol as byproduct of bio-diesel. The use of a PdAg membrane reactor at middle reaction temperature. International Journal of Hydrogen Energy. 2011;36:3827-34. 
Figures Captions

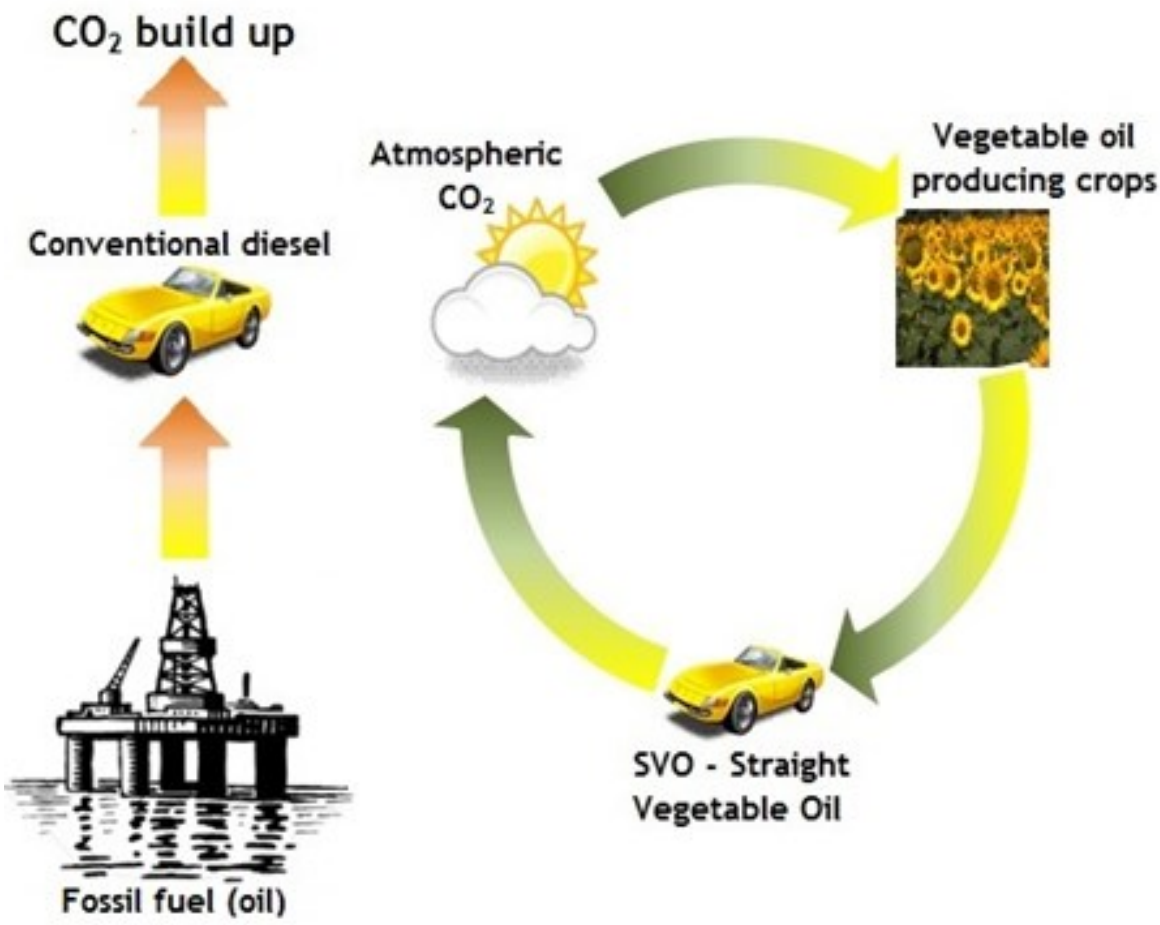

Fig. 1 - Comparison of $\mathrm{CO}_{2}$ emission cycles between conventional diesel and biodiesel.

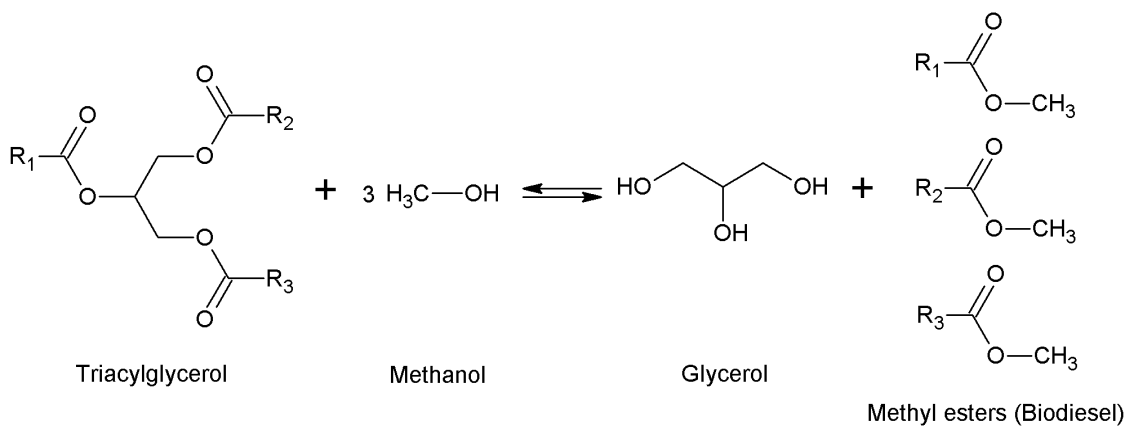

Fig. 2 - Overall reaction of triglycerides transesterification with methanol for biodiesel production yielding glycerol as by-product. 


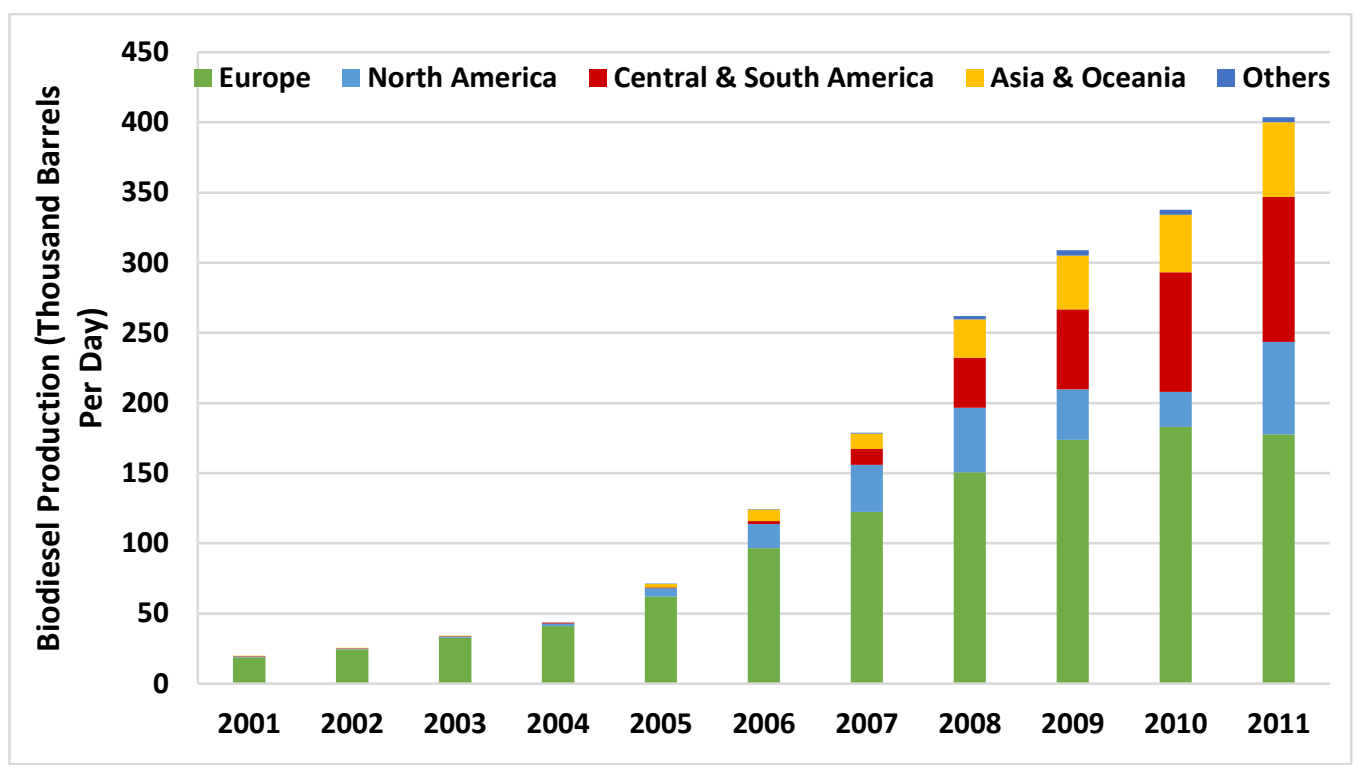

Fig. 3 - Evolution of worldwide biodiesel production between 2001-2011 [3].
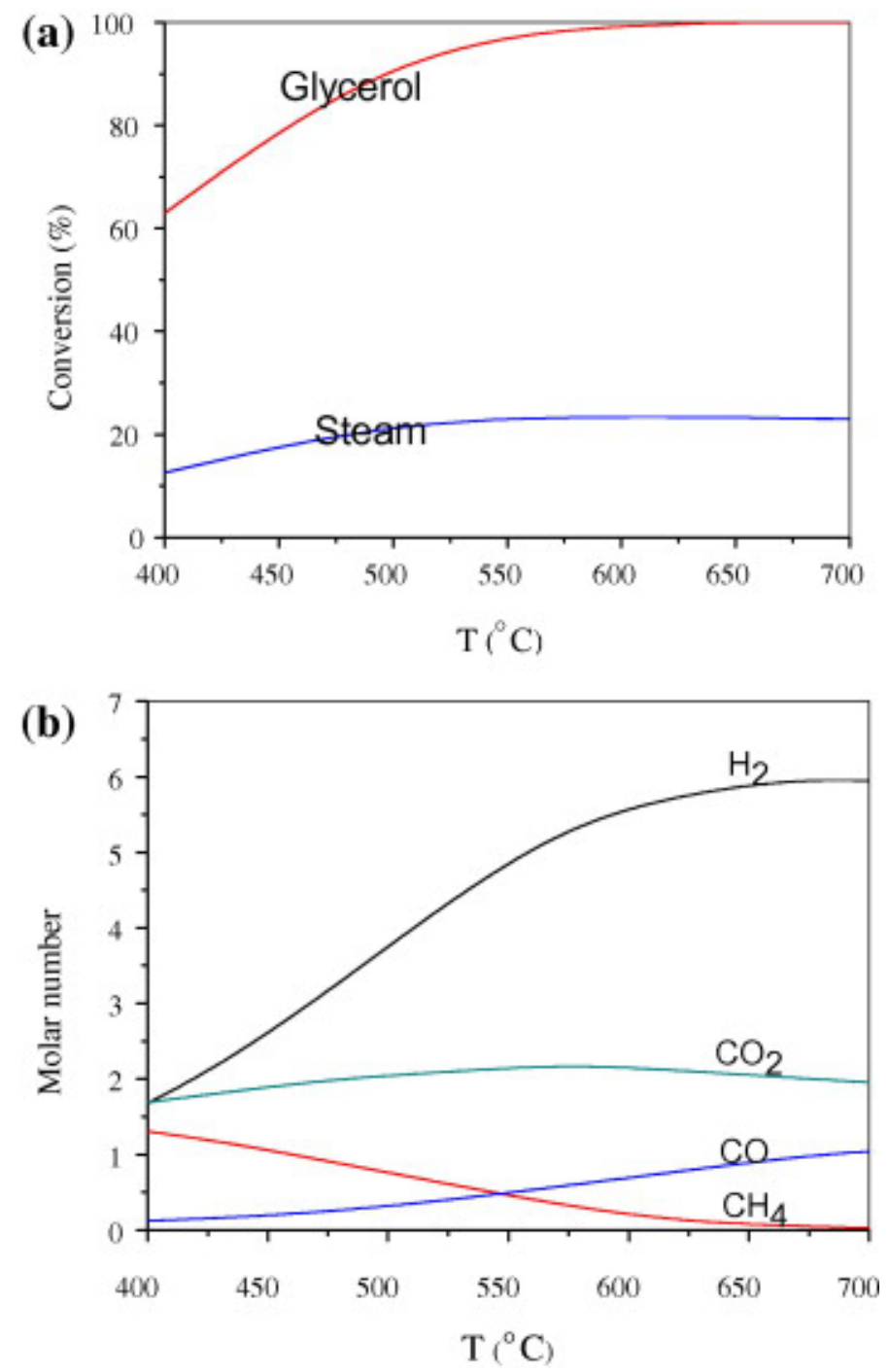

Fig. 4 - Thermodynamic equilibrium of GSR: (a) Glycerol and steam conversions and (b) moles of gas products. Water/glycerol feed ratio (WGFR) $=9$, atmospheric pressure and considering eq. (2, 5 and 6). Reprinted from Chemical Engineering Journal, 220, Wang C, Dou B, Chen H, 
Song $\mathrm{Y}, \mathrm{Xu} \mathrm{Y}$, Du $\mathrm{X}$, et al., Hydrogen production from steam reforming of glycerol by Ni-Mg-Al based catalysts in a fixed-bed reactor, 133-42, Copyright (2013), with permission from Elsevier.

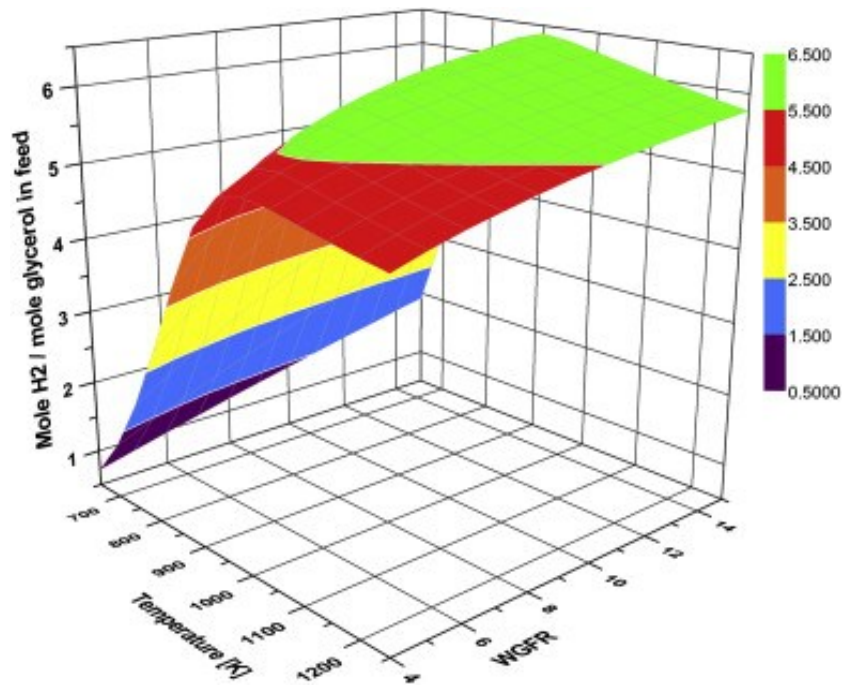

Fig. 5 - Moles of $\mathrm{H}_{2}$ produced per mole of glycerol during GSR as function of WGFR and temperature at $1 \mathrm{~atm}$ and considering eq. (2, 3, 5 and 6). Reprinted from Energy, 64, Hajjaji N, Chahbani A, Khila Z, Pons M-N., A comprehensive energy-exergy-based assessment and parametric study of a hydrogen production process using steam glycerol reforming, 473-83, Copyright (2014), with permission from Elsevier.

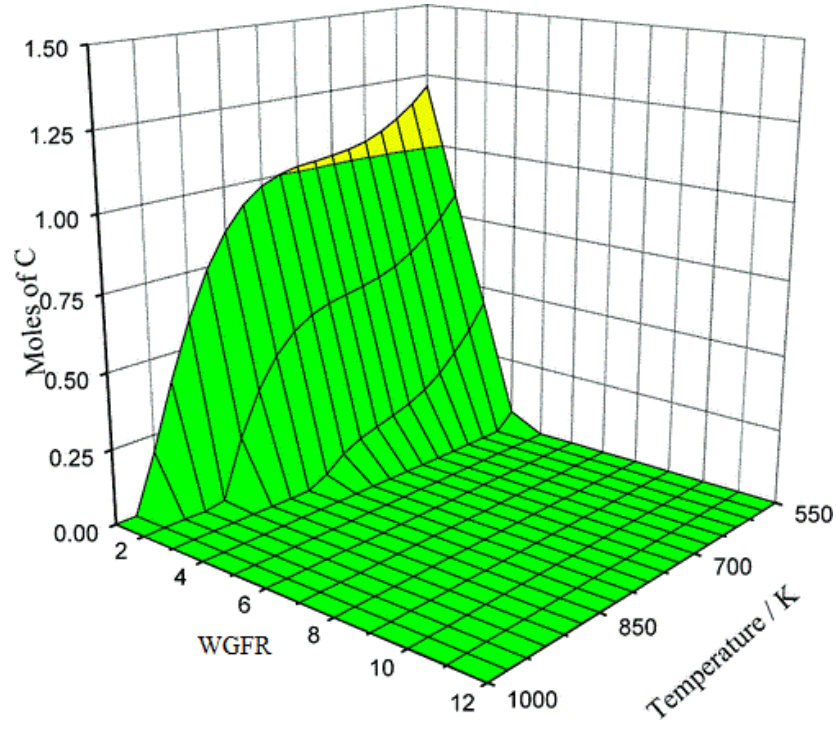

Fig. 6 - Moles of carbon formed as a function of WGFR and temperature at 50 atm. Adapted with permission from (Wang X, Li S, Wang H, Liu B, Ma X. Thermodynamic analysis of glycerin steam reforming. Energy and Fuels. 2008; 22:4285-91). Copyright (2008) American Chemical Society. 


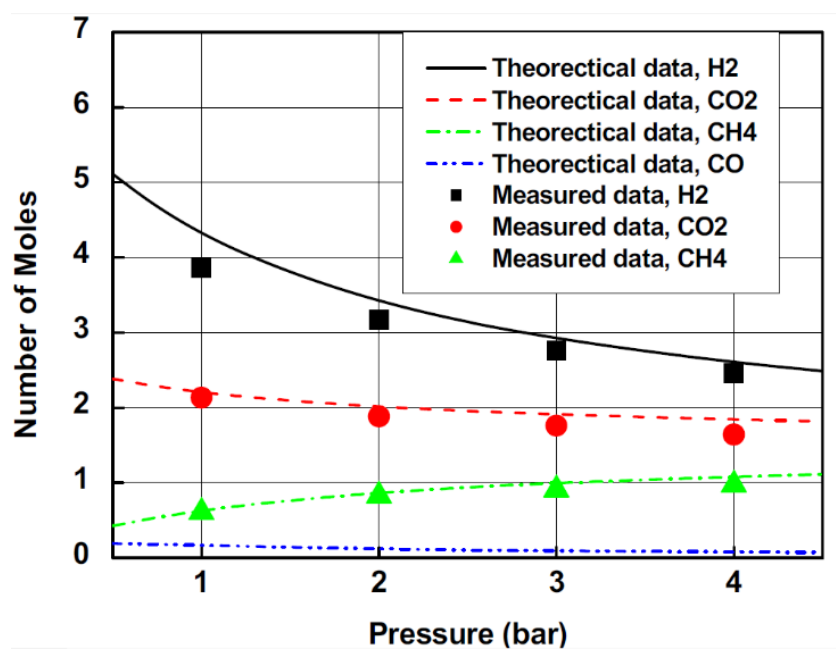

Fig. 7 - Effect of total pressure on the number of moles of different components in the equilibrium. $T=450{ }^{\circ} \mathrm{C}, \mathrm{WGFR}=9$, feeding reactants to inert gas ratio $=1: 4$. Reprinted from Renewable Energy, 36, Chen H, Ding Y, Cong NT, Dou B, Dupont V, Ghadiri M, et al., A comparative study on hydrogen production from steam-glycerol reforming: thermodynamics and experimental, 779-88, Copyright (2011), with permission from Elsevier.
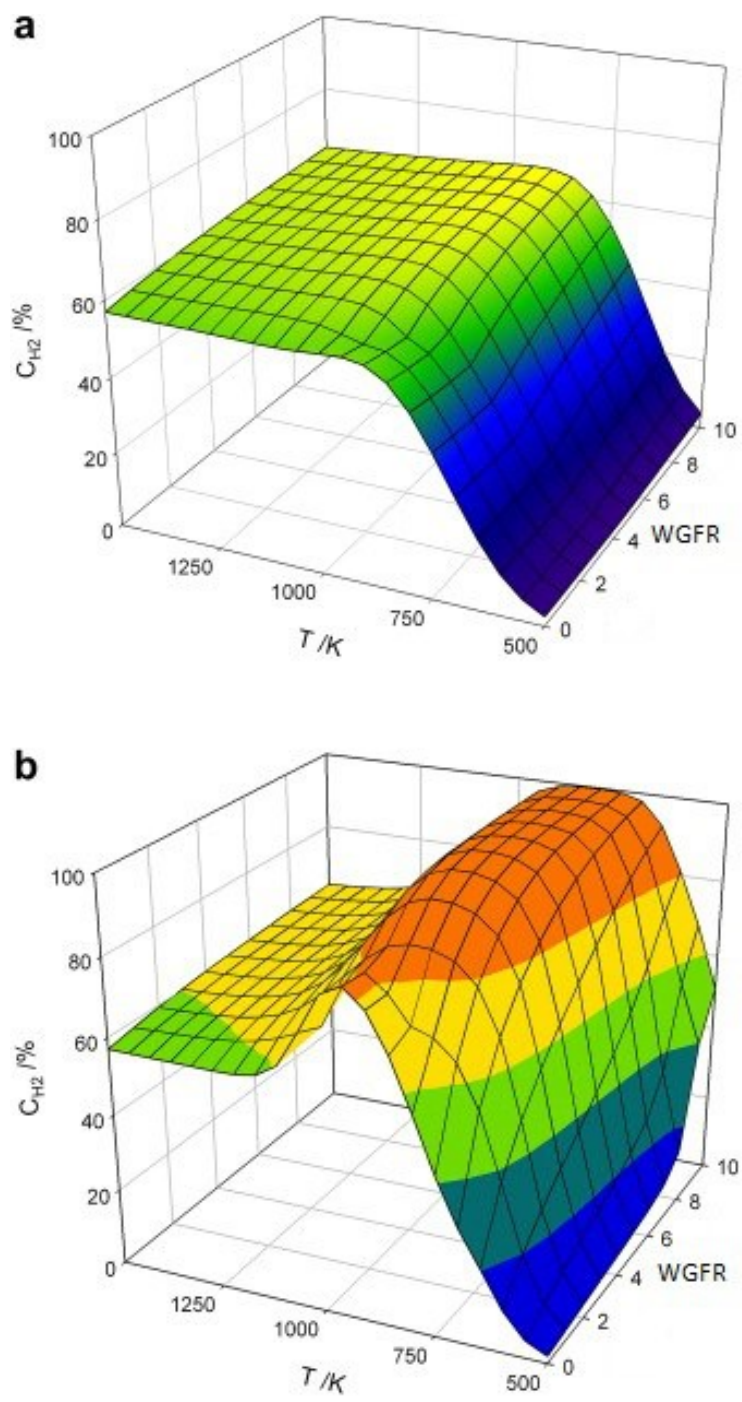
Fig. 8 - Hydrogen concentration (dry basis) in equilibrium as function of temperature and WGFR in (a) GSR and (b) SEGSR, at $1 \mathrm{~atm}$. Adapted from International Journal of Hydrogen Energy, 35, $\mathrm{Li} Y$, Wang W, Chen B, Cao Y, Thermodynamic analysis of hydrogen production via glycerol steam reforming with $\mathrm{CO} 2$ adsorption, 7768-77, Copyright (2010), with permission from International Journal of Hydrogen Energy.

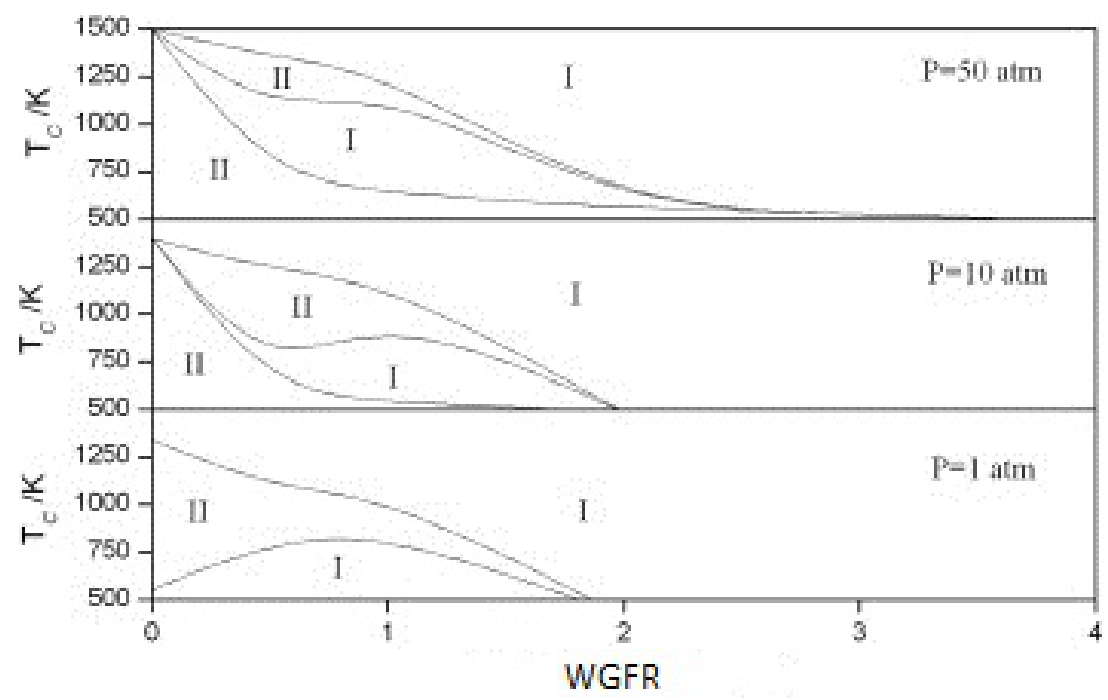

Fig. 9 - Coke free (I) and coke formed (II) regions in SEGSR as a function of temperature and WGFR, at $1 \mathrm{~atm}, 10 \mathrm{~atm}$ and $50 \mathrm{~atm}$. Reprinted from International Journal of Hydrogen Energy, 35, Li Y, Wang W, Chen B, Cao Y, Thermodynamic analysis of hydrogen production via glycerol steam reforming with $\mathrm{CO} 2$ adsorption, 7768-77, Copyright (2010), with permission from International Journal of Hydrogen Energy. 

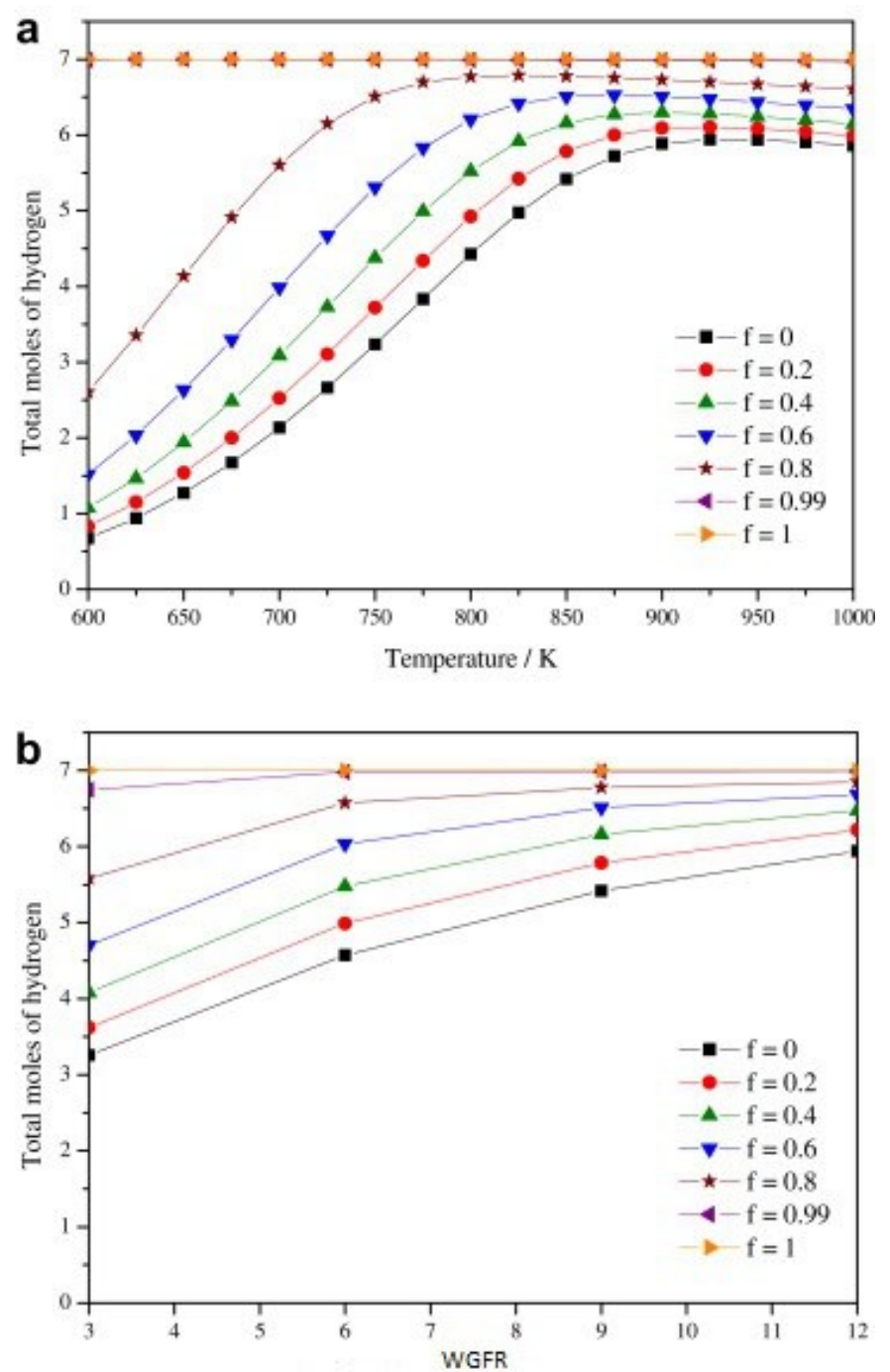

Fig. 10 - Effect of (a) temperature (WGFR = 9) and (b) WGFR $(T=850 \mathrm{~K})$ at $1 \mathrm{~atm}$ and fraction of hydrogen removal $(f)$ on the production of $\mathrm{H}_{2}$. Adapted from International Journal of Hydrogen Energy, 35, Wang X, Wang N, Li M, Li S, Wang S, Ma X, Hydrogen production by glycerol steam reforming with in situ hydrogen separation: A thermodynamic investigation, 10252-6, Copyright (2010), with permission from International Journal of Hydrogen Energy.

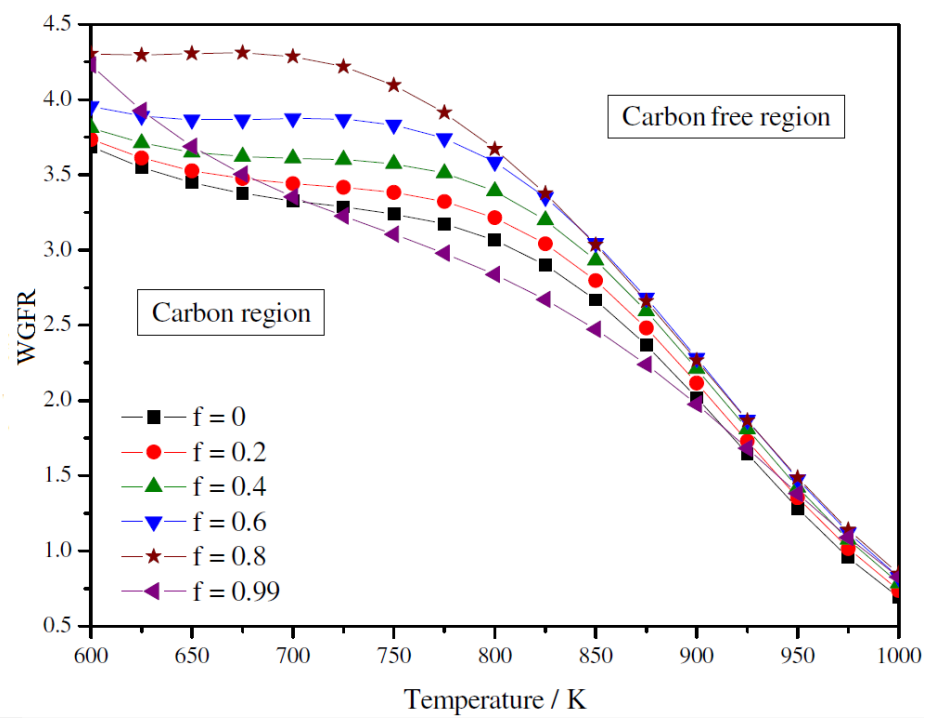


Fig. 11 - Carbon formation as function of WGFR and temperature at $1 \mathrm{~atm}$, for different values of $f$. Adapted from International Journal of Hydrogen Energy, 35, Wang X, Wang N, Li M, Li S, Wang $S$, Ma X, Hydrogen production by glycerol steam reforming with in situ hydrogen separation: A thermodynamic investigation, 10252-6, Copyright (2010), with permission from International Journal of Hydrogen Energy.

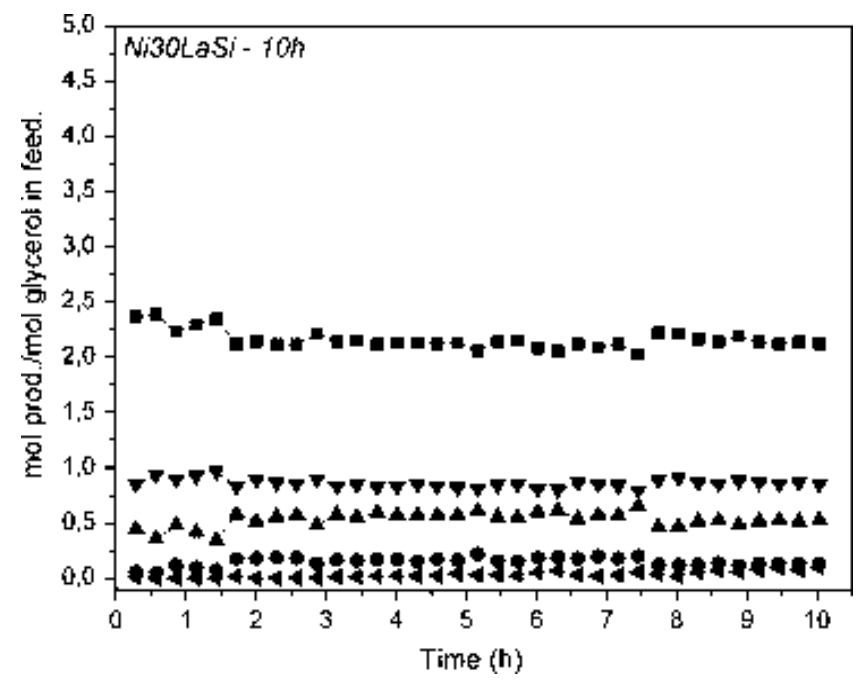

Fig. 12 - Yield of gaseous products formed during the stability reaction of GSR with the $30 \mathrm{wt} . \%$ $\mathrm{La}_{2} \mathrm{O}_{3}$ content catalyst $\left(\square \mathrm{H}_{2} \bullet \mathrm{CH}_{4} \bullet \mathrm{CO} \sim \mathrm{CO}_{2} \backsim \mathrm{C}_{2} \mathrm{H}_{4}\right)$. Reprinted from Fuel, 105, Thyssen VV, Maia TA, Assaf EM., Ni supported on La2O3-SiO2 used to catalyze glycerol steam reforming, 358-63, Copyright (2013), with permission from Elsevier.

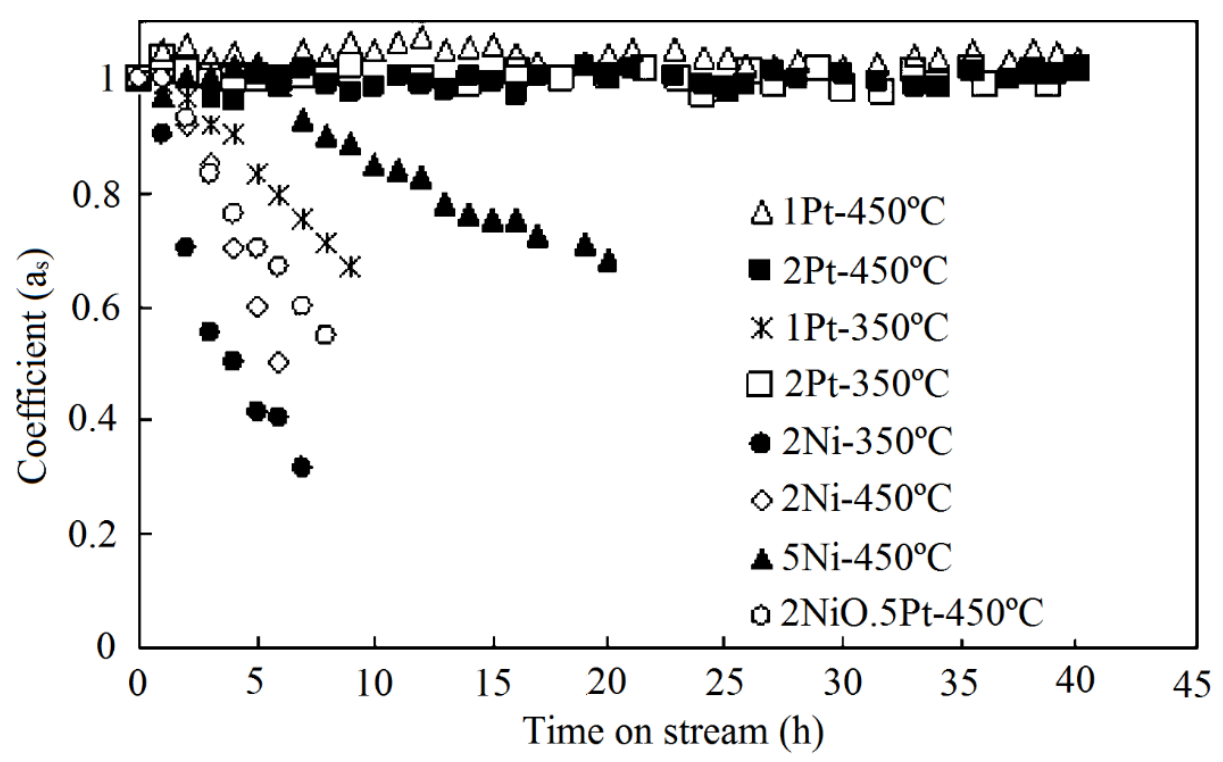

Fig. 13 - Activity over time-on-stream at $350{ }^{\circ} \mathrm{C}$ and $450{ }^{\circ} \mathrm{C}$ with different catalysts supported on $\mathrm{SiO}_{2}$ (feed flow rate of $0.5 \mathrm{~mL} \cdot \mathrm{min}^{-1}, 10 \mathrm{wt}$.\% aqueous solution of glycerol and for a residence time of $0.88 \mathrm{~min}$ ). Reprinted from Catalysis Today, 172, Pompeo F, Santori GF, Nichio NN., Hydrogen production by glycerol steam reforming with $\mathrm{Pt} / \mathrm{SiO} 2$ and $\mathrm{Ni} / \mathrm{SiO} 2$ catalysts, 183-8, Copyright (2011), with permission from Elsevier. 


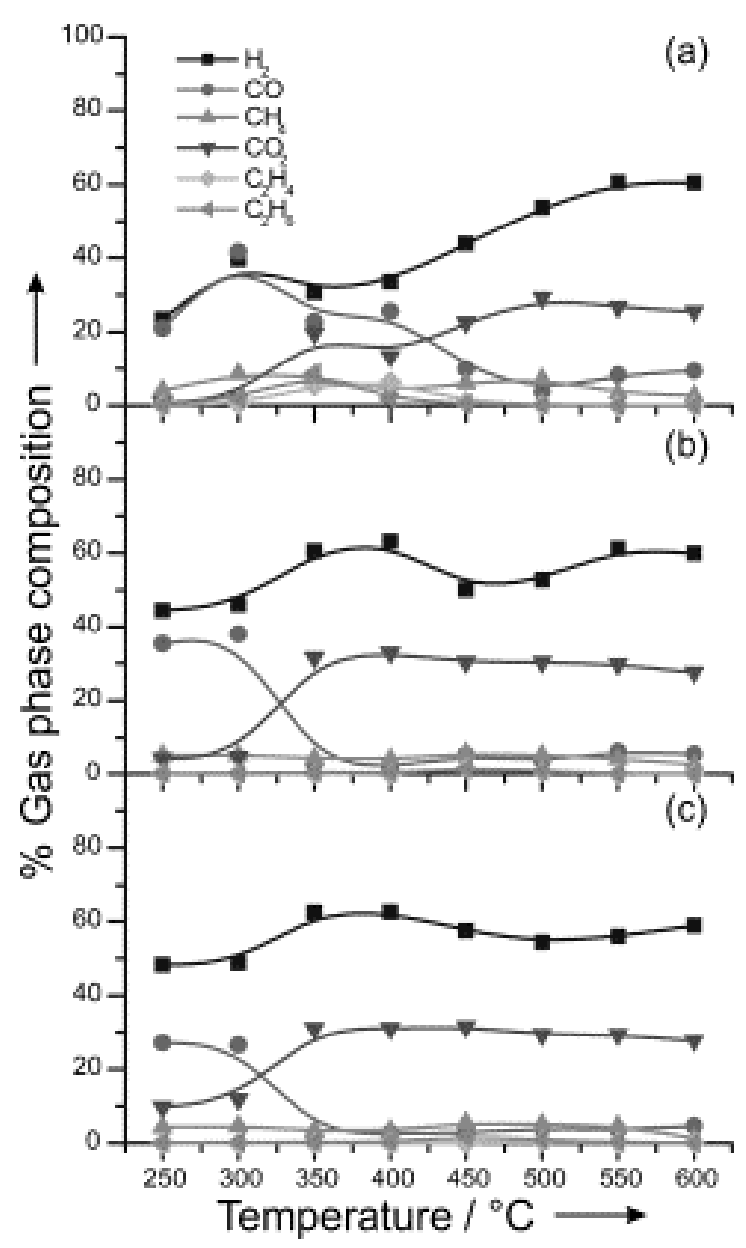

Fig. 14 - Stability tests over doped $\mathrm{Pt} / \mathrm{Al}_{2} \mathrm{O}_{3}$ catalysts. Top: glycerol conversion to gas-phase products. Bottom: gas-phase composition using (a) $\mathrm{Pt} / \mathrm{La}_{2} \mathrm{O}_{3} / \mathrm{Al}_{2} \mathrm{O}_{3}$ and (b) $\mathrm{Pt} / \mathrm{CeO}_{2} / \mathrm{Al}_{2} \mathrm{O}_{3}$ catalyst. Conditions: $1.00 \mathrm{~g}$ catalyst, $0.32 \mathrm{~mL} \cdot \mathrm{min}^{-1}$ of $\mathrm{C}_{3} \mathrm{H}_{8} \mathrm{O}_{3}$ (30 wt.\%; aqueous solution), $T=$ $350{ }^{\circ} \mathrm{C}$. Reprinted from ChemSusChem., 3, Montini T, Singh R, Das P, Lorenzut B, Bertero N, Riello $\mathrm{P}$, et al., Renewable $\mathrm{H} 2$ from glycerol steam reforming: Effect of $\mathrm{La} 2 \mathrm{O} 3$ and $\mathrm{CeO} 2$ addition to Pt/Al2O3 catalysts, 619-28, Copyright $\odot 2010$ WILEY-VCH Verlag GmbH \& Co. KGaA, Weinheim.

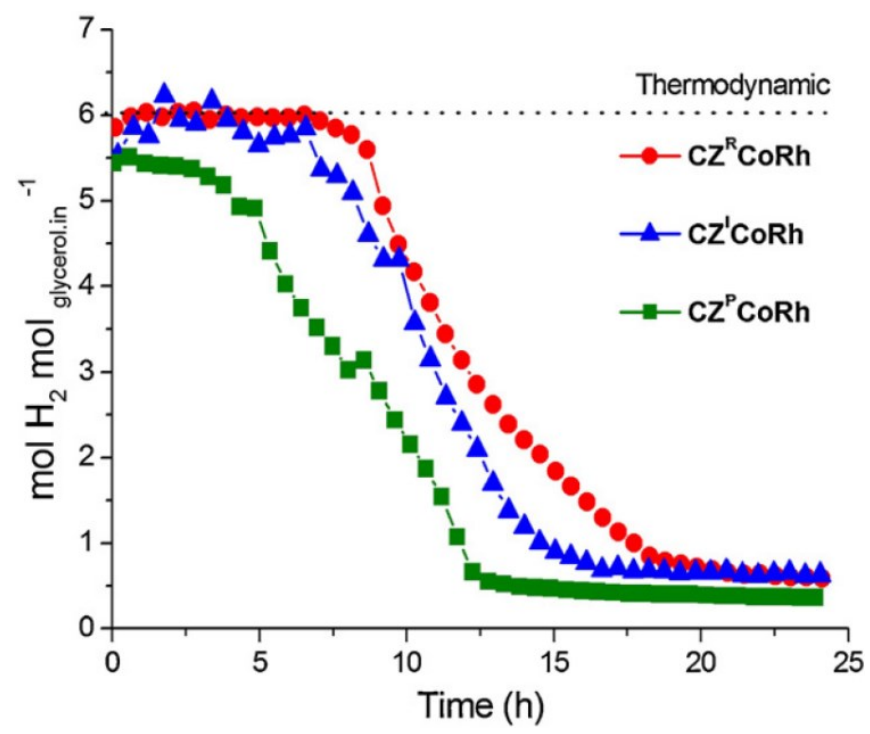


Fig. 15 - Evolution of the $\mathrm{H}_{2}$ production in GSR over $\mathrm{Ce}_{0.53} \mathrm{Zr}_{2.97} \mathrm{Co}_{0.47} \mathrm{Rh}_{0.03} \mathrm{O}_{8 . \delta}$ with poor ceria content $\left(\mathrm{CZ}^{\mathrm{P} C \mathrm{CORh}}\right), \mathrm{Ce}_{2} \mathrm{Zr}_{1.5} \mathrm{CO}_{0.47} \mathrm{Rh}_{0.03} \mathrm{O}_{8-\delta}$ with intermediate ceria content ( $\left.\mathrm{CZ} \mathrm{C}^{\prime} \mathrm{CoRh}\right)$, and $\mathrm{Ce}_{2.59} \mathrm{Zr}_{0.91} \mathrm{Co}_{0.47} \mathrm{Rh}_{0.03} \mathrm{O}_{8 . \delta}$ with rich ceria content $\left(\mathrm{CZ}^{\mathrm{R}} \mathrm{CoRh}\right)$. Conditions: temperature $650{ }^{\circ} \mathrm{C}$, WGFR of 9 and atmospheric pressure. Thermodynamic value expected using the UNIQUAC model: $6.06 \mathrm{molH}_{2} \cdot \mathrm{mol}_{\text {glycerol. }}{ }^{-1}$. Reprinted from Applied Catalysis B: Environmental, 132-133, Martínez T LM, Araque M, Vargas JC, Roger AC., Effect of Ce/Zr ratio in CeZr-CoRh catalysts on the hydrogen production by glycerol steam reforming, 499-510, Copyright (2013), with permission from Elsevier.

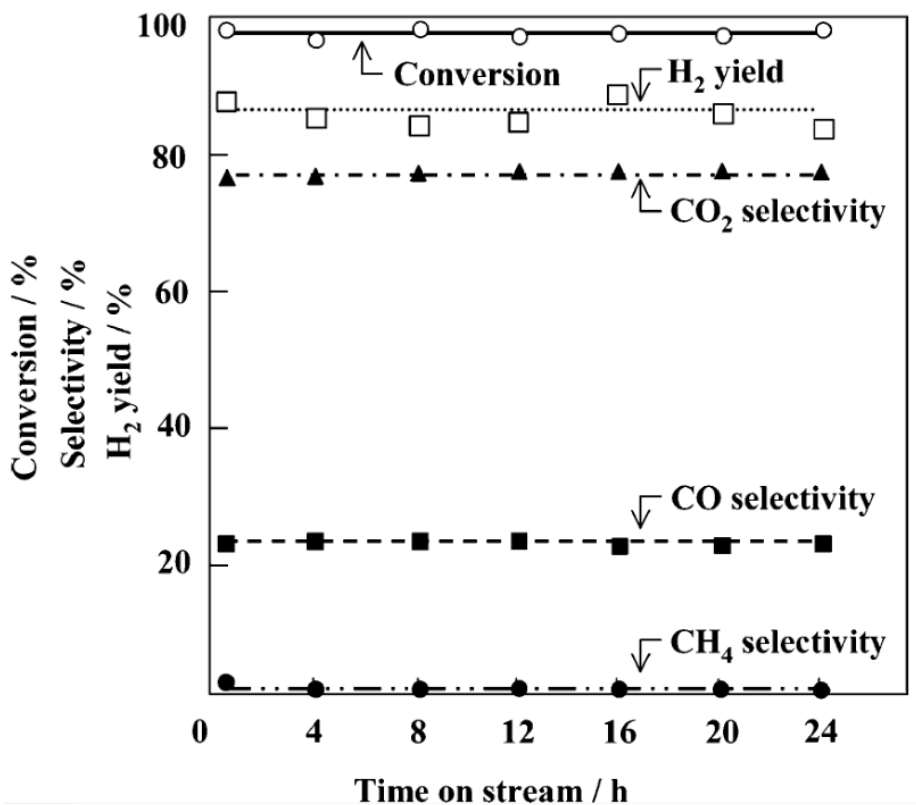

Fig. 16 - Stability tests over $3 \mathrm{wt} . \% \mathrm{Ru} / \mathrm{Y}_{2} \mathrm{O}_{3}$ catalyst for $24 \mathrm{~h}$ in the $\mathrm{GSR}$, at $600{ }^{\circ} \mathrm{C}$ and sweep gas space velocity of $80000 \mathrm{~mL} \cdot \mathrm{gcat}^{-1} \cdot \mathrm{h}^{-1}$. Reprinted with permission from (Hirai T, Ikenaga NO, Miyake T, Suzuki T. Production of hydrogen by steam reforming of glycerin on ruthenium catalyst. Energy and Fuels. 2005;19:1761-2). Copyright (2005) American Chemical Society.

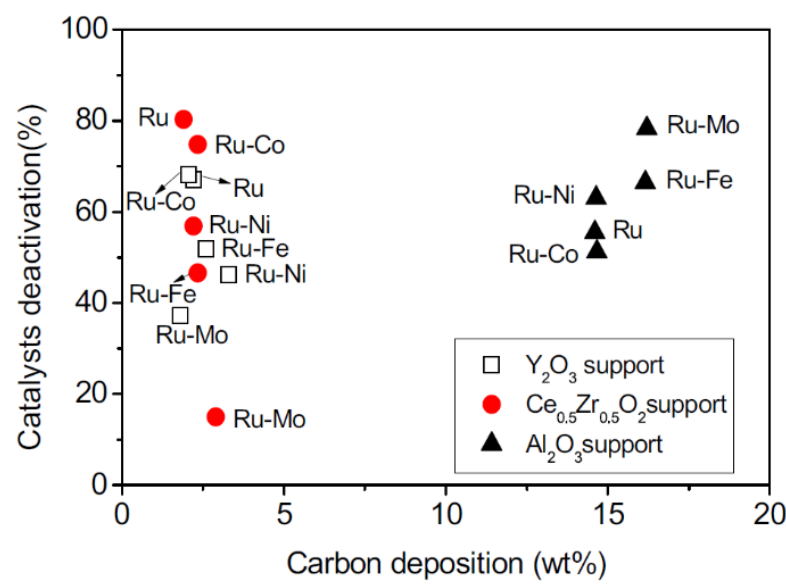

Fig. 17 - Deactivation of catalysts (\%) with respect to the amount of solid carbonaceous species deposited (wt.\%) on the catalysts after $10 \mathrm{~h}$ of reaction at $600{ }^{\circ} \mathrm{C}$ (feed conditions: WGFR of 12 , spatial velocity of $\left.876-2340 \mu \mathrm{mol} \cdot \mathrm{g}_{\mathrm{cat}^{-}}{ }^{-1} \cdot \mathrm{min}^{-1}\right)$. Reprinted from International Journal of Hydrogen Energy, 38, Kim J, Lee D, Glycerol steam reforming on supported Ru-based catalysts for hydrogen production for fuel cells, 11853-62, Copyright (2013), with permission from International Journal of Hydrogen Energy. 


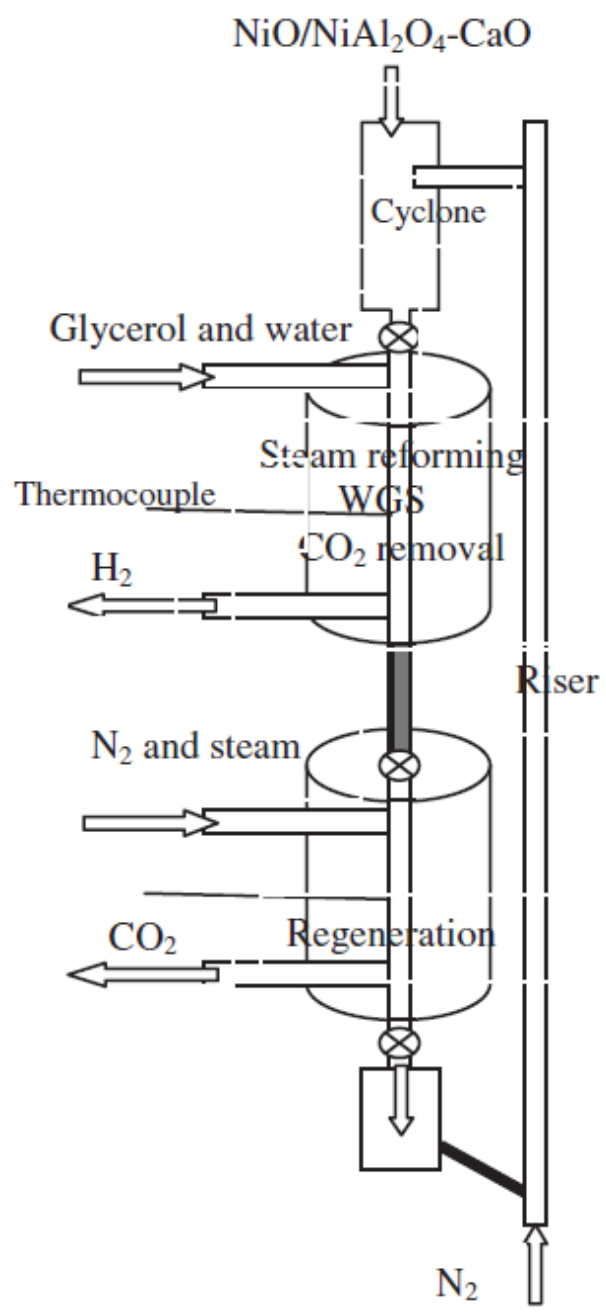

Fig. 18 - Scheme of the continuous SEGSR system. Reprinted from International Journal of Hydrogen Energy, 38, Dou B, Wang C, Chen H, Song Y, Xie B, Continuous sorption-enhanced steam reforming of glycerol to high-purity hydrogen production, 11902-9, Copyright (2013), with permission from International Journal of Hydrogen Energy.

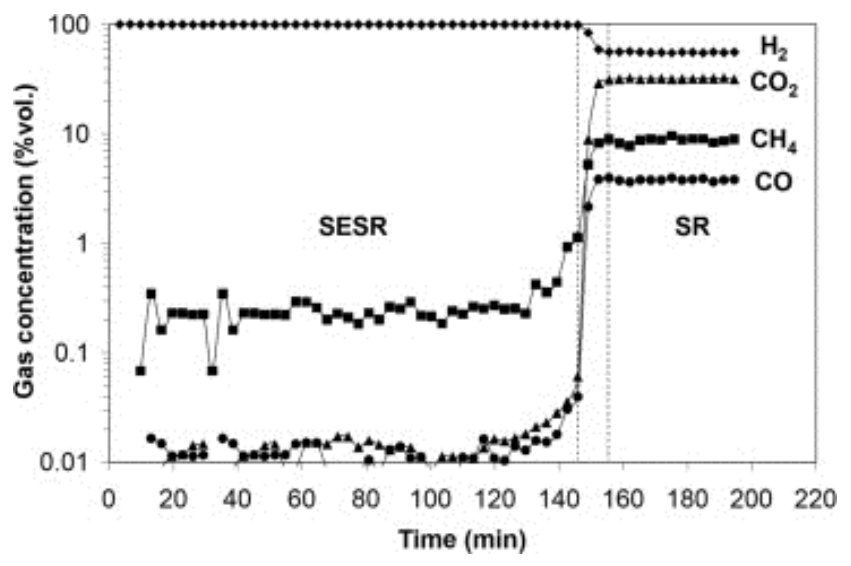

Fig. 19 - Evolution with time of the gas product composition $\left(\mathrm{N}_{2}\right.$ free and dry basis) during SEGSR at $550^{\circ} \mathrm{C}$, WGFR of $9,1 \mathrm{~atm}$, contact time of $1.09 \mathrm{~h}$ and sorbent/catalyst $=5$ ). Reprinted from International Journal of Hydrogen Energy, 37, Fermoso J, He L, Chen D, Production of high purity hydrogen by sorption enhanced steam reforming of crude glycerol, 14047-54, Copyright (2012), with permission from International Journal of Hydrogen Energy. 

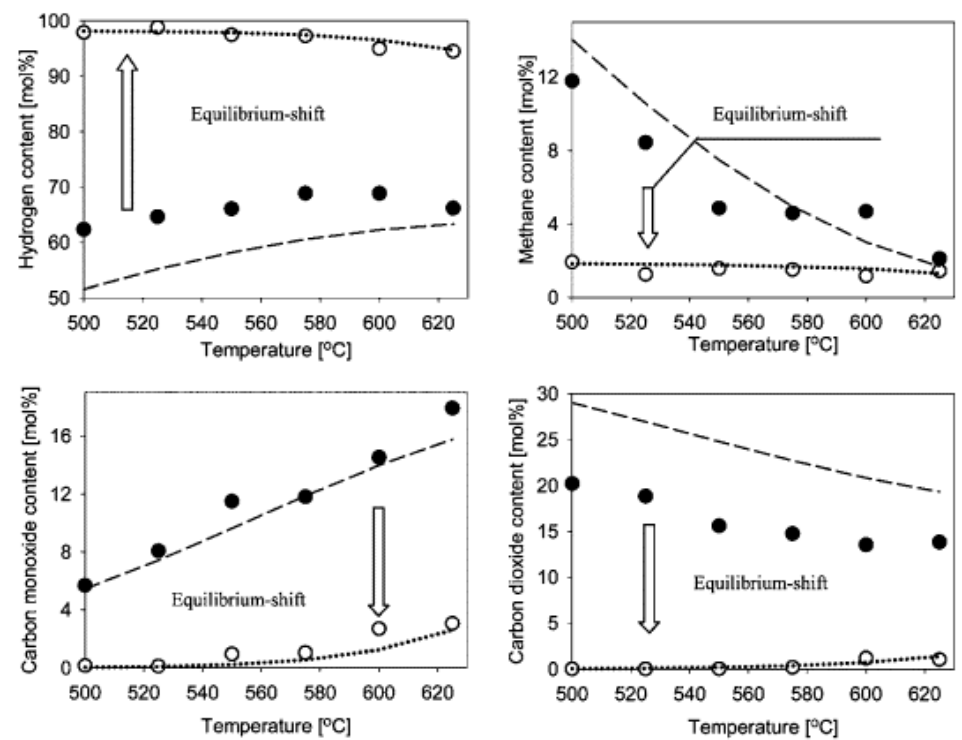

Fig. 20 - Product gas composition (dry basis) of GSR with and without in situ $\mathrm{CO}_{2}$ removal at WGFR of $4,1 \mathrm{~atm}$, catalyst/sorbent ratio of $5 / 2.5$ and contact time of $1 \mathrm{~h}(\cdots$ thermodynamic equilibrium of SEGSR, --- thermodynamic equilibrium of GSR, O experimental results for SEGSR, - experimental results for GSR). [He L, Parra JMS, Blekkan EA, Chen D. Towards efficient hydrogen production from glycerol by sorption enhanced steam reforming. Energy and Environmental Science. 2010;3:1046-56] - Reproduced by permission of The Royal Society of Chemistry. Available at http://pubs.rsc.org/en/content/articlepdf/2010/ee/b922355j.

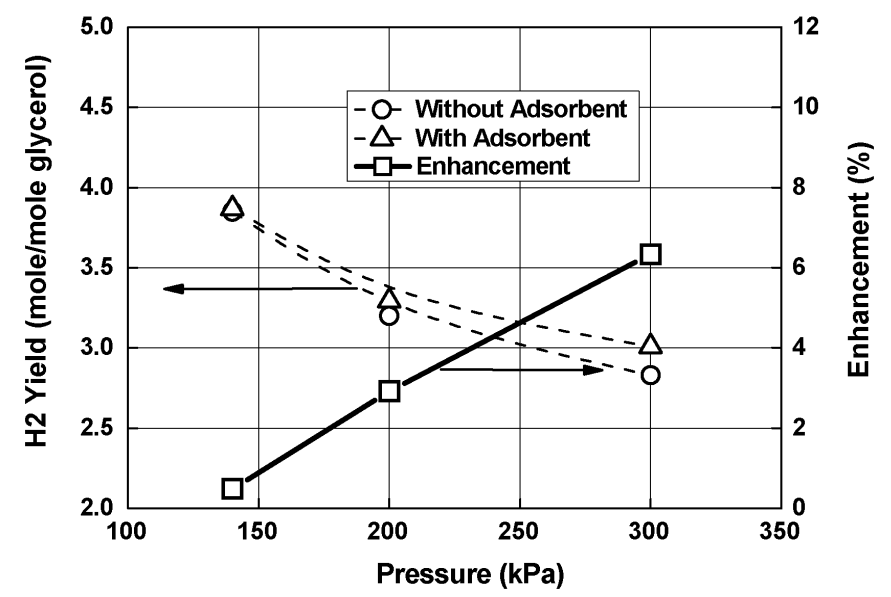

Fig. 21 - Effect of pressure on the hydrogen yield during SEGSR at $450^{\circ} \mathrm{C}$, WGFR of 9 , glycerol/ $\mathrm{N}_{2}$ volume ratio of 0.025 , using a $\mathrm{Ni}$-based catalyst and microsized hydrotalcite as $\mathrm{CO}_{2}$ sorbent. Reprinted from Chemical Engineering Research and Design, 89, Chen H, Ding Y, Cong NT, Dou $B$, Dupont $\mathrm{V}$, Ghadiri $\mathrm{M}$, et al., Progress in low temperature hydrogen production with simultaneous CO2 abatement, 1774-82, Copyright (2011), with permission from Elsevier. 


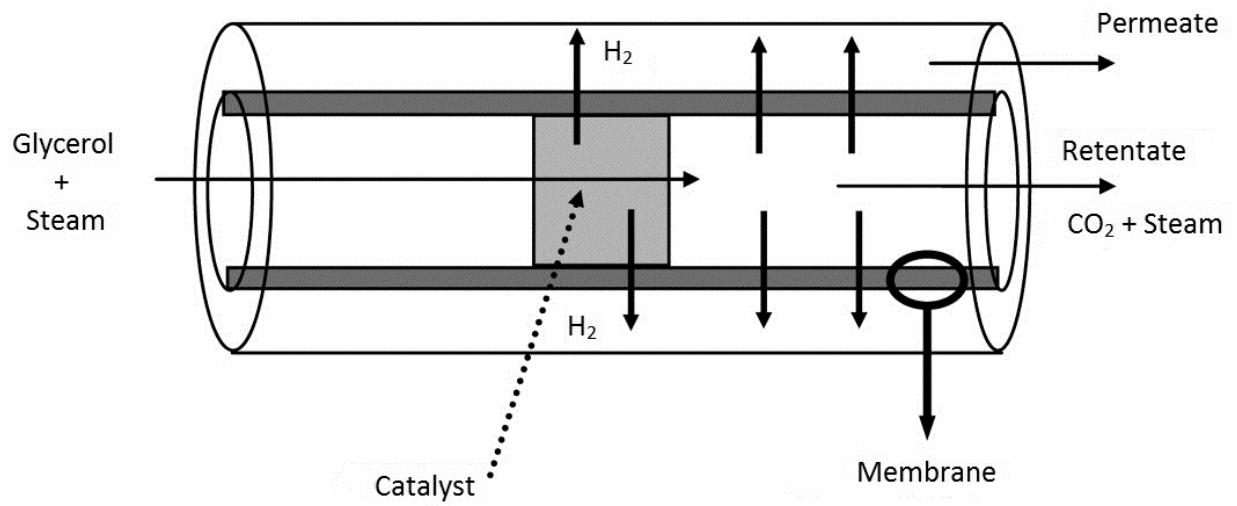

Fig. 22 - Scheme of a MR for the GSR reaction. Adapted from Journal of Catalysis, 252, Haag S, Burgard M, Ernst B., Beneficial effects of the use of a nickel membrane reactor for the dry reforming of methane: Comparison with thermodynamic predictions, 190-204, Copyright (2007), with permission from Elsevier.

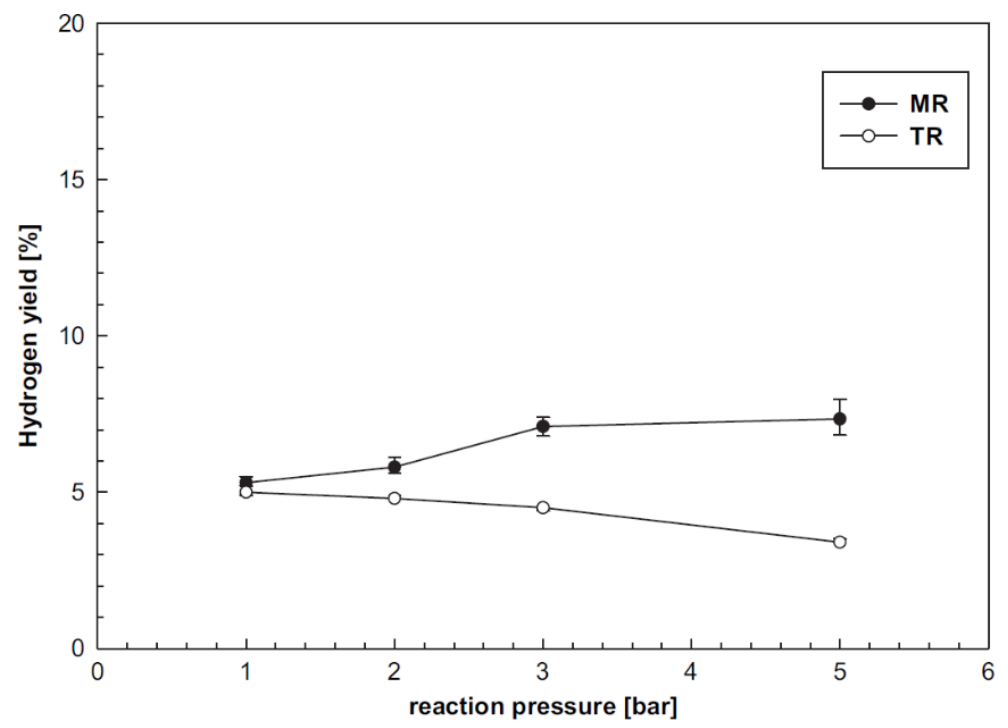

Fig. 23 - Effect of reaction pressure on the hydrogen yield for the traditional reactor (TR) and membrane reactor (MR) at $400{ }^{\circ} \mathrm{C}$, WGFR of 6 , WHSV of $1.0 \mathrm{~h}^{-1}$, counter-current configuration of sweep-gas, atmospheric pressure in the permeate side and $Q_{\text {sweep-gas }} / Q_{\text {glycerol-in }}=11.9$. Reprinted from International Journal of Hydrogen Energy, 36, lulianelli A, Seelam PK, Liguori $\mathrm{S}$, Longo T, Keiski R, Calabrò V, et al., Hydrogen production for PEM fuel cell by gas phase reforming of glycerol as byproduct of bio-diesel. The use of a Pd-Ag membrane reactor at middle reaction temperature, 3827-34, Copyright (2011), with permission from International Journal of Hydrogen Energy. 


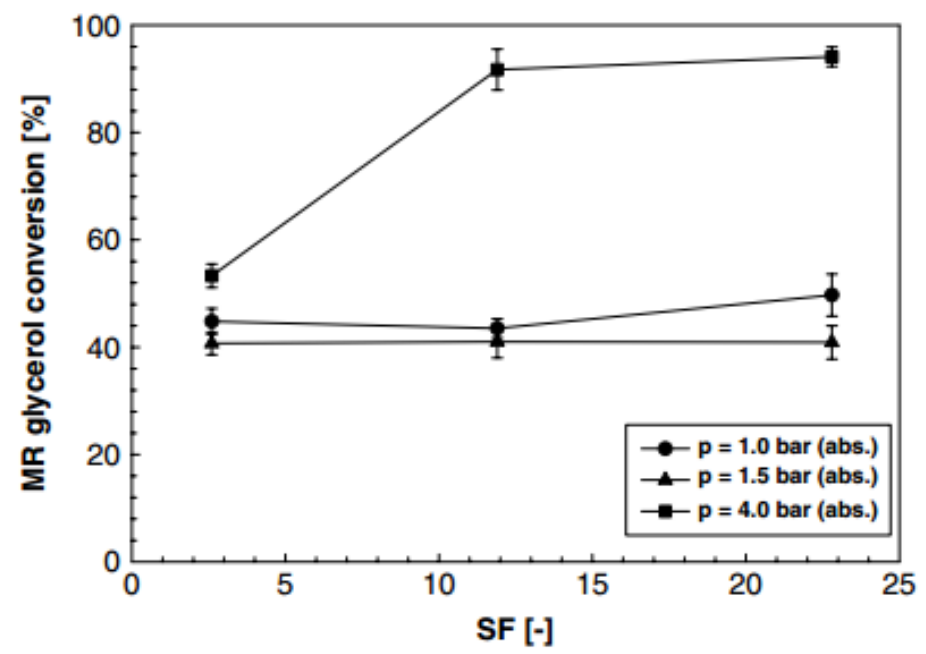

Fig. 24 - Dependency of glycerol conversion the sweep factor (SF) in the Pd-Ag MR at different reaction pressures, $400{ }^{\circ} \mathrm{C}$, WGFR of 6 and WHSV of $1.01 \mathrm{~h}^{-1}$. Reprinted from Asia-Pacific Journal of Chemical Engineering, 5, lulianelli A, Longo T, Liguori S, Basile A., Production of hydrogen via glycerol steam reforming in a Pd-Ag membrane reactor over Co-Al2O3 catalyst, 138-45, Copyright $\odot 2009$ Curtin University of Technology and John Wiley \& Sons, Ltd. 
Table 1 - Summary of the catalytic performance and operating conditions of different Ni-based catalysts on GSR.

\begin{tabular}{|c|c|c|c|c|c|}
\hline Catalyst & Operating Conditions & $\begin{array}{l}\text { Conversion } \\
\text { (\%) }\end{array}$ & Type of Conversion & $\begin{array}{l}\mathrm{H}_{2} \text { Yield }(\%)^{\mathrm{a}} \text { / } \\
\text { Selectivity } \\
(\%)\end{array}$ & Reference \\
\hline 11.6 wt.\% Ni/ $\mathrm{CeO}_{2}$ & $\begin{array}{l}600{ }^{\circ} \mathrm{C}, 1 \mathrm{~atm}, \text { feed flow rate }= \\
0.5 \mathrm{~mL} \cdot \mathrm{min}^{-1} \text { and WGFR }=9\end{array}$ & 100 & Glycerol conversion ${ }^{\mathrm{b}}$ & n.d. ${ }^{c} / 70$ & {$[48]$} \\
\hline 9.62 wt.\% Ni/MgO & $\begin{array}{l}600{ }^{\circ} \mathrm{C}, 1 \mathrm{~atm}, \text { feed flow rate }= \\
0.5 \mathrm{~mL} \cdot \mathrm{min}^{-1} \text { and WGFR }=9\end{array}$ & 100 & Glycerol conversion ${ }^{\mathrm{b}}$ & n.d. ${ }^{c} / 40$ & {$[48]$} \\
\hline 12.7 wt. $\% \mathrm{Ni} / \mathrm{TiO}_{2}$ & $\begin{array}{l}600{ }^{\circ} \mathrm{C}, 1 \mathrm{~atm}, \text { feed flow rate }= \\
0.5 \mathrm{~mL} \cdot \mathrm{min}^{-1} \text { and WGFR }=9\end{array}$ & 60 & Glycerol conversion ${ }^{\mathrm{b}}$ & n.d.c/15 & {$[48]$} \\
\hline 10 wt. $\% \mathrm{Ni} / \mathrm{ZrO}_{2}$ & $\begin{array}{l}650{ }^{\circ} \mathrm{C}, 1 \mathrm{~atm}, \text { feed flow rate }= \\
0.06 \mathrm{~mL} \cdot \mathrm{min}^{-1} \text { and } 10 \mathrm{wt} . \% \\
\text { glycerol }\end{array}$ & $72(20 h)^{d}$ & $\begin{array}{l}\text { Glycerol conversion } \\
\text { to gaseous products }\end{array}$ & $65 /$ n.d. ${ }^{c}$ & {$[51]$} \\
\hline $\begin{array}{l}12.6 \text { wt. } \% \mathrm{Ni} / \gamma- \\
\mathrm{Al}_{2} \mathrm{O}_{3}\end{array}$ & $\begin{array}{l}500{ }^{\circ} \mathrm{C}, 4 \mathrm{~atm}, \mathrm{WHSV}^{\mathrm{f}}=7.7 \mathrm{~h}^{-1} \\
\text { and } 10 \mathrm{wt} . \% \text { glycerol }\end{array}$ & $100(8 h)^{d}$ & Glycerol conversion ${ }^{b}$ & $50 /$ n.d. ${ }^{c}$ & [53] \\
\hline 10 wt. $\% \mathrm{Ni} / \mathrm{SiC}$ & $\begin{array}{l}400^{\circ} \mathrm{C}, 1 \mathrm{~atm}, \mathrm{WHSV}^{\mathrm{f}}=33.3 \mathrm{~h}^{-1} \\
\text { and WGFR }=9\end{array}$ & $95.2(60 h)^{d}$ & $\begin{array}{l}\text { Glycerol conversion } \\
\text { to gaseous products }\end{array}$ & n.d. ${ }^{c} /$ n.d. ${ }^{c}$ & {$[60]$} \\
\hline
\end{tabular}

a Based on the thermodynamic limit established in each work;

b Calculation based on the total amount of glycerol converted;

$$
\text { c n.d.: not determined; }
$$

d Time of operation after which the data was collected;

e Calculation based on the amount of carbon (in glycerol) converted into gaseous products $\left(\mathrm{CO}_{2}, \mathrm{CO}\right.$ and $\left.\mathrm{CH}_{4}\right)$;

${ }^{f}$ WHSV: weight hourly space velocity. 
Table 2 - Summary of the catalytic performance and operating conditions of different promoted Ni-based catalysts on GSR.

\begin{tabular}{|c|c|c|c|c|c|}
\hline Catalyst & $\begin{array}{l}\text { Operating } \\
\text { Conditions }\end{array}$ & $\begin{array}{l}\text { Conversion } \\
\text { (\%) }\end{array}$ & Type of Conversion & $\begin{array}{l}\mathrm{H}_{2} \text { Yield (\%) } \\
\text { /Selectivity (\%) }\end{array}$ & Reference \\
\hline $\begin{array}{l}8.4 \% \mathrm{Ni} / \gamma-\mathrm{Al}_{2} \mathrm{O}_{3} / 6 \\
\text { wt.\% } \mathrm{La}_{2} \mathrm{O}_{3}\end{array}$ & $\begin{array}{l}500{ }^{\circ} \mathrm{C}, 4 \mathrm{~atm}, \\
\mathrm{WHSV}^{\mathrm{b}}=7.7 \mathrm{~h}^{-1} \text { and } \\
10 \text { wt.\% glycerol }\end{array}$ & $100(8 h)^{c}$ & Glycerol conversion $^{d}$ & 99.7/n.d. ${ }^{\mathrm{e}}$ & {$[22]$} \\
\hline $\begin{array}{l}11.9 \mathrm{wt} \% \mathrm{Ni} / \gamma- \\
\mathrm{Al}_{2} \mathrm{O}_{3} / 4.3 \mathrm{wt} . \% \mathrm{CeO}_{2}\end{array}$ & $\begin{array}{l}500{ }^{\circ} \mathrm{C}, 4 \mathrm{~atm}, \\
\mathrm{WHSV}^{\mathrm{b}}=7.7 \mathrm{~h}^{-1} \text { and } \\
10 \text { wt. } \% \text { glycerol }\end{array}$ & $100(8 h)^{c}$ & Glycerol conversion ${ }^{d}$ & $80.3 /$ n.d. $^{e}$ & [53] \\
\hline $\begin{array}{l}13.4 \text { wt. } \% \mathrm{Ni} / \gamma-\mathrm{Al}_{2} \mathrm{O}_{3} \\
-7 \text { wt. } \% \mathrm{ZrO}_{2}\end{array}$ & $\begin{array}{l}500{ }^{\circ} \mathrm{C}, 4 \mathrm{~atm}, \\
\mathrm{WHSV}^{\mathrm{b}}=7.7 \mathrm{~h}^{-1} \text { and } \\
10 \text { wt. } \% \text { glycerol }\end{array}$ & $100(7-8 h)^{c}$ & Glycerol conversiond & $62 /$.d. $^{\mathrm{e}}$ & [65] \\
\hline $\begin{array}{l}10 \text { wt. } \% \text { Ni/MoLaCa- } \\
\text { LTA }\end{array}$ & $\begin{array}{l}600{ }^{\circ} \mathrm{C} \text {, feed flow } \\
\text { rate }=0.63 \mathrm{~mL} \cdot \mathrm{min}^{-1} \\
\text { and } 35 \mathrm{wt} . \% \text { glycerol }\end{array}$ & $82.03(100 \mathrm{~h})^{\mathrm{c}}$ & $\begin{array}{l}\text { Glycerol conversion } \\
\text { to gaseous products }\end{array}$ & n.d. ${ }^{e} /$ n.d. ${ }^{e}$ & [66] \\
\hline
\end{tabular}


Table 3 - Summary of the catalytic performance and operating conditions of different Pt-based catalysts on GSR.

\begin{tabular}{|c|c|c|c|c|c|}
\hline Catalyst & Operating Conditions & $\begin{array}{l}\text { Conversion } \\
\text { (\%) }\end{array}$ & Type of Conversion & $\begin{array}{l}\mathrm{H}_{2} \text { Yield }(\%)^{\mathrm{a}} / \\
\text { Selectivity (\%) }\end{array}$ & Reference \\
\hline $\begin{array}{l}3 \text { wt.\% } \\
\mathrm{Pt} / \mathrm{Y}_{2} \mathrm{O}_{3}\end{array}$ & $\begin{array}{l}600{ }^{\circ} \mathrm{C}, 1 \mathrm{~atm}, \text { feed flow rate }= \\
0.06 \mathrm{~mL} \cdot \mathrm{min}^{-1} \text {, carrier gas flow } \\
\text { rate }=33 \mathrm{~mL} \cdot \mathrm{min}^{-1} \text { and } \mathrm{WGFR}=24\end{array}$ & $100(2.5-3 h)^{b}$ & $\begin{array}{l}\text { Glycerol conversion } \\
\text { to gaseous products }\end{array}$ & $90.0 /$ n.d.d & [54] \\
\hline $5 \% \mathrm{Pt} / \mathrm{C}$ & $\begin{array}{l}400{ }^{\circ} \mathrm{C}, 5 \text { atm, volumetric flow } \\
\text { rate at reactor inlet }=210 \\
\mathrm{~mL} \cdot \mathrm{min}^{-1} \text { and } \mathrm{WGFR}=9\end{array}$ & $60(3 h)^{b}$ & Glycerol conversion ${ }^{\mathrm{e}}$ & $37.0 /$ n.d. ${ }^{d}$ & [89] \\
\hline $\begin{array}{l}1 \mathrm{wt} . \% \\
\mathrm{Pt} / \mathrm{SiO}_{2}\end{array}$ & $\begin{array}{l}350^{\circ} \mathrm{C}, 1 \mathrm{~atm} \text {, Space time }=0.88 \\
\text { min, feed flow rate }=0.5 \mathrm{~mL} \cdot \mathrm{min}^{-} \\
{ }^{1} \text { and } 10 \mathrm{wt} . \% \text { glycerol }\end{array}$ & $85(2 h)^{b}$ & $\begin{array}{l}\text { Glycerol conversion } \\
\text { to gaseous products }\end{array}$ & n.d.c/n.d.d & [91] \\
\hline $\begin{array}{l}2 \mathrm{wt} . \% \\
\mathrm{Pt} / \mathrm{SiO}_{2}\end{array}$ & $\begin{array}{l}350{ }^{\circ} \mathrm{C}, 1 \mathrm{~atm} \text {, Space time }=0.88 \\
\text { min, feed flow rate }=0.5 \mathrm{~mL} \cdot \mathrm{min}^{-} \\
{ }^{1} \text { and } 10 \mathrm{wt} . \% \text { glycerol }\end{array}$ & $100(2 h)^{b}$ & $\begin{array}{l}\text { Glycerol conversion } \\
\text { to gaseous products }\end{array}$ & n.d.d/n.d.d & [91] \\
\hline $\begin{array}{l}3 \text { wt. } \% \\
\mathrm{Pt} / \mathrm{Al}_{2} \mathrm{O}_{3}\end{array}$ & $\begin{array}{l}350^{\circ} \mathrm{C}, 1 \mathrm{~atm} \text {, feed flow rate }= \\
0.32 \mathrm{~mL} \cdot \mathrm{min}^{-1} \text { and } 30 \mathrm{wt} . \% \\
\text { glycerol }\end{array}$ & $\approx 21.0$ & $\begin{array}{l}\text { Glycerol conversion } \\
\text { to gaseous products }\end{array}$ & n.d. ${ }^{d} /$ n.d. ${ }^{d}$ & [92] \\
\hline
\end{tabular}


Table 4 - Summary of the catalytic performance and operating conditions of different promoted Pt-based catalysts on GSR.

\begin{tabular}{|c|c|c|c|c|c|}
\hline Catalyst & Operating Conditions & $\begin{array}{l}\text { Conversion } \\
\text { (\%) }\end{array}$ & Type of Conversion & $\begin{array}{l}\mathrm{H}_{2} \text { Yield (\%) }{ }^{\mathrm{a}} \\
\text { Selectivity (\%) }\end{array}$ & Reference \\
\hline $\begin{array}{l}\mathrm{Pt} / 4 \mathrm{wt} . \% \mathrm{CeO}_{2}-1 \\
\text { wt. } \% \mathrm{ZrO}_{2}-\alpha-\mathrm{Al}_{2} \mathrm{O}_{3}\end{array}$ & $\begin{array}{l}350^{\circ} \mathrm{C} \text {, space time }=6 \mathrm{~min} \text {, } \\
\text { feed flow rate }=0.1 \mathrm{~mL} \cdot \mathrm{min}^{-1} \\
\text { and } 10 \mathrm{wt} . \% \text { glycerol }\end{array}$ & $78.0(1 \mathrm{~h})^{\mathrm{b}}$ & $\begin{array}{l}\text { Glycerol conversion } \\
\text { to gaseous products }{ }^{c}\end{array}$ & n.d. ${ }^{d} / 72.5$ & {$[97]$} \\
\hline $\begin{array}{l}3 \text { wt. } \% \mathrm{Pt} / 20 \\
\text { wt. } \% \mathrm{CeO}_{2} / \mathrm{Al}_{2} \mathrm{O}_{3}\end{array}$ & $\begin{array}{l}350^{\circ} \mathrm{C}, 1 \mathrm{~atm}, \text { feed flow rate } \\
=0.32 \mathrm{~mL} \cdot \mathrm{min}^{-1} \text { and } 30 \mathrm{wt} . \% \\
\text { glycerol }\end{array}$ & 88.0 & $\begin{array}{l}\text { Glycerol conversion } \\
\text { to gaseous products }{ }^{c}\end{array}$ & n.d.d/n.d.d & {$[92]$} \\
\hline $\begin{array}{l}3 \text { wt. } \% \text { Pt } / 5 \text { wt. } \% \\
\mathrm{La}_{2} \mathrm{O}_{3} / \mathrm{Al}_{2} \mathrm{O}_{3}\end{array}$ & $\begin{array}{l}350^{\circ} \mathrm{C}, 1 \mathrm{~atm}, \text { feed flow rate } \\
=0.32 \mathrm{~mL} \cdot \mathrm{min}^{-1} \text { and } 30 \mathrm{wt} . \% \\
\text { glycerol }\end{array}$ & 91.0 & $\begin{array}{l}\text { Glycerol conversion } \\
\text { to gaseous products }{ }^{c}\end{array}$ & n.d.d/n.d.d & {$[92]$} \\
\hline
\end{tabular}


Table 5 - Summary of the catalytic performance and operating conditions of different non-promoted and promoted Co-based catalysts on GSR.

\begin{tabular}{|c|c|c|c|c|c|}
\hline Catalyst & Operating Conditions & $\begin{array}{l}\text { Conversion } \\
\text { (\%) }\end{array}$ & $\begin{array}{l}\text { Type of } \\
\text { Conversion }\end{array}$ & $\begin{array}{l}\mathrm{H}_{2} \text { Yield (\%) }{ }^{\mathrm{a}} \\
\text { Selectivity (\%) }\end{array}$ & Reference \\
\hline $15 \% \mathrm{Co} / \mathrm{CeO}_{2}$ & $\begin{array}{l}425^{\circ} \mathrm{C}, 1 \mathrm{~atm}, \mathrm{GHSV}^{\mathrm{b}}=11000 \\
\mathrm{~mL} \cdot \mathrm{g}_{\text {cat. }}{ }^{-1} \cdot \mathrm{h}^{-1} \text { and } \mathrm{G} / \mathrm{W} / \mathrm{He}^{\mathrm{c}}= \\
2 / 18 / 80 \text { vol. } \%\end{array}$ & 100 & Not specified & n.d. ${ }^{d} / 88.0$ & [106] \\
\hline $\begin{array}{l}15 \text { wt. } \% \\
\mathrm{Co} / \mathrm{Al}_{2} \mathrm{O}_{3}\end{array}$ & $\begin{array}{l}500{ }^{\circ} \mathrm{C}, 1 \mathrm{~atm}, \mathrm{GHSV}^{\mathrm{b}}=50000 \\
\mathrm{~mL} \cdot \mathrm{g}_{\text {cat. }}{ }^{-1} \cdot \mathrm{h}^{-1} \text { and } \mathrm{p}_{\text {glycerol }}=7.40 \\
\mathrm{kPa} \text { and } \mathrm{p}_{\text {steam }}=57.02 \mathrm{kPa}\end{array}$ & $\approx 13.0$ & $\begin{array}{l}\text { Glycerol } \\
\text { conversion to } \\
\text { gaseous products }\end{array}$ & $77.0^{f} / 63.0$ & [107] \\
\hline $\begin{array}{l}5 \text { wt. } \% \mathrm{Co}-10 \\
\text { wt. } \% \mathrm{Ni} / \mathrm{Al}_{2} \mathrm{O}_{3}\end{array}$ & $\begin{array}{l}525^{\circ} \mathrm{C}, 1 \text { atm, GHSV }=50000 \\
\mathrm{~mL} \cdot \mathrm{g}_{\text {cat. }}{ }^{-1} \cdot \mathrm{h}^{-1} \text { and } 30 \mathrm{wt} . \%\end{array}$ & - & - & $79.1 / 65.3$ & [108] \\
\hline
\end{tabular}


Table 6 - Summary of the catalytic performance and operating conditions of different non-promoted and promoted Ru-based catalysts on GSR.

\begin{tabular}{|c|c|c|c|c|c|}
\hline Catalyst & Operating Conditions & $\begin{array}{l}\text { Conversion } \\
\text { (\%) }\end{array}$ & Type of Conversion & $\begin{array}{l}\mathrm{H}_{2} \text { Yield (\%) }{ }^{\mathrm{a}} \\
\text { Selectivity(\%) }\end{array}$ & Reference \\
\hline $5 \% \mathrm{Ru} / \mathrm{Al}_{2} \mathrm{O}_{3}$ & $\begin{array}{l}400{ }^{\circ} \mathrm{C}, 1 \mathrm{~atm}, \text { feed flow rate } \\
=0.20 \mathrm{~mL} \cdot \mathrm{min}^{-1} \text { and WGFR }=9\end{array}$ & $68.1(2 h)^{b}$ & Glycerol conversion ${ }^{c}$ & $37.0 /$ n.d. ${ }^{d}$ & {$[114]$} \\
\hline 3 wt. $\% \mathrm{Ru} / \mathrm{Y}_{2} \mathrm{O}_{3}$ & $\begin{array}{l}600{ }^{\circ} \mathrm{C}, 1 \mathrm{~atm}, \mathrm{GHSV}^{\mathrm{e}}=80000 \\
\mathrm{~mL} \cdot \mathrm{g}_{\text {cat. }}{ }^{-1} \cdot \mathrm{h}^{-1} \text { and WGFR }=9\end{array}$ & $\approx 100(24 \mathrm{~h})^{\mathrm{b}}$ & $\begin{array}{l}\text { Glycerol conversion } \\
\text { to gaseous products }\end{array}$ & $85 / 90.0^{\mathrm{g}}$ & {$[117]$} \\
\hline $\begin{array}{l}0.59 \text { wt. } \% \text { Ru- } 0.23 \\
\text { wt. } \% \mathrm{Sn} / \mathrm{Mg}(\mathrm{Al}) 0\end{array}$ & $\begin{array}{l}650{ }^{\circ} \mathrm{C}, 1 \mathrm{~atm}, \text { feed flow rate } \\
=0.06 \mathrm{~mL} \cdot \mathrm{min}^{-1} \text { and } 10 \mathrm{wt} . \% \\
\text { glycerol }\end{array}$ & $87.5(20 h)^{b}$ & $\begin{array}{l}\text { Glycerol conversion } \\
\text { to gaseous products }\end{array}$ & $60 /$ n.d. ${ }^{d}$ & {$[120]$} \\
\hline \multirow[t]{2}{*}{$\begin{array}{l}0.06 \text { wt. } \% \\
\mathrm{Ru} / \mathrm{Mg}(\mathrm{Al}) \mathrm{O}\end{array}$} & $\begin{array}{l}550^{\circ} \mathrm{C}, 1 \mathrm{~atm}, \mathrm{WHSV}^{\mathrm{h}}=327.3 \\
\mathrm{~h}^{-1 \mathrm{i}} \text { and } 10 \mathrm{wt} . \% \text { glycerol }\end{array}$ & $97(20 h)^{b}$ & $\begin{array}{l}\text { Glycerol conversion } \\
\text { to gaseous products }\end{array}$ & $91.0 / 97.0^{j}$ & {$[121]$} \\
\hline & $\begin{array}{r}{ }^{a} \text { Based on the thermodynamic } \\
\text { b Time of operation after w } \\
\text { c Calculation based on the tota } \\
d \text { n.d.: not } \\
\text { e GHSV: gas hour } \\
\text { on the amount of carbon (in glycer } \\
\text { g taken f } \\
\text { h WHSV: weight ho } \\
{ }^{i} \text { Calculat } \\
{ }^{\mathrm{j} \mathrm{CO}_{2} \text { se }}\end{array}$ & $\begin{array}{l}\text { imit established } \\
\text { ich the data was } \\
\text { amount of glycer } \\
\text { etermined; } \\
\text { / space velocity; } \\
\text { ) converted into } \\
\text { m [122]; } \\
\text { rly space velocity } \\
\text { d value; } \\
\text { ctivity. }\end{array}$ & $\begin{array}{l}\text { n each work; } \\
\text { collected; } \\
\text { ol converted; } \\
\text { gaseous products }\left(\mathrm{CO}_{2}, \mathrm{CC}\right.\end{array}$ & and $\mathrm{CH}_{4}$ ); & \\
\hline
\end{tabular}


Table 7 - Summary of the catalytic performance and operating conditions of different noble metal-based catalysts on GSR.

\begin{tabular}{|c|c|c|c|c|c|}
\hline Catalyst & Operating Conditions & $\begin{array}{l}\text { Conversion } \\
\text { (\%) }\end{array}$ & $\begin{array}{l}\text { Type of } \\
\text { Conversion }\end{array}$ & $\begin{array}{l}\mathrm{H}_{2} \text { Yield (\%) }{ }^{\mathrm{a}} \\
\text { Selectivity (\%) }\end{array}$ & Reference \\
\hline $\mathrm{Ir} / \mathrm{CeO}_{2}$ & $\begin{array}{l}400{ }^{\circ} \mathrm{C}, 1 \mathrm{~atm}, \mathrm{GHSV}^{\mathrm{b}}=11000 \\
\mathrm{~mL} \cdot \mathrm{g}_{\text {cat. }}{ }^{-1} \cdot \mathrm{h}^{-1} \text { and } \mathrm{G} / \mathrm{W} / \mathrm{He}^{\mathrm{c}}= \\
2 / 18 / 80 \text { vol. } \%\end{array}$ & 100 & Not specified & n.d. d/85.6 & {$[106]$} \\
\hline 5 wt. $\%$ Rh $/ \mathrm{Al}_{2} \mathrm{O}_{3}$ & $\begin{array}{l}650^{\circ} \mathrm{C}, 1 \mathrm{~atm}, \mathrm{GHSV}^{\mathrm{b}}=5000 \mathrm{~h}^{-} \\
1 \text { and WGFR }=9\end{array}$ & $50.0(100 h)^{e}$ & $\begin{array}{l}\text { Glycerol } \\
\text { conversion to } \\
\text { gaseous products }\end{array}$ & $35.7^{\mathrm{g}} /$ n.d. $^{\mathrm{d}}$ & {$[128]$} \\
\hline 1 wt. $\% \mathrm{Pd} / \mathrm{Al}_{2} \mathrm{O}_{3}$ & $\begin{array}{l}600{ }^{\circ} \mathrm{C}, 1 \mathrm{~atm}, \text { feed flow rate }= \\
0.05 \mathrm{~mL} \cdot \mathrm{min}^{-1} \text { and WGFR }=6\end{array}$ & $80.0(2 h)^{e}$ & $\begin{array}{l}\text { Glycerol } \\
\text { conversion to } \\
\text { gaseous products }\end{array}$ & $55.0 / 70.0$ & {$[133]$} \\
\hline 10 wt. $\% \mathrm{Ce} / \mathrm{Al}_{2} \mathrm{O}_{3}$ & $\begin{array}{l}600^{\circ} \mathrm{C}, 1 \mathrm{~atm}, \text { feed flow rate }= \\
0.05 \mathrm{~mL} \cdot \mathrm{min}^{-1} \text { and WGFR }=6\end{array}$ & $55.0(2 h)^{e}$ & $\begin{array}{l}\text { Glycerol } \\
\text { conversion to } \\
\text { gaseous products }^{f}\end{array}$ & $42.0 / 80.0$ & {$[133]$} \\
\hline
\end{tabular}


Table 8 - Activation energies and reaction orders for the GSR reaction over different catalyst.

\begin{tabular}{|c|c|c|c|c|c|c|}
\hline Catalyst & Operating conditions $^{\mathrm{a}}$ & Preparation method & $\begin{array}{l}E_{a} \\
\left(k J \cdot \mathrm{mol}^{-1}\right)\end{array}$ & $\begin{array}{l}\text { Reaction order } \\
\text { for glycerol }^{\mathrm{b}}\end{array}$ & $\begin{array}{l}\text { Reaction order } \\
\text { for steam }^{b}\end{array}$ & Reference \\
\hline $\begin{array}{l}15 \mathrm{wt} . \% \mathrm{Ni}-10 \mathrm{wt} . \% \\
\mathrm{ZrO}_{2} / \mathrm{CeO}_{2}\end{array}$ & $1 \mathrm{~atm}, 600-700^{\circ} \mathrm{C}$ & $\begin{array}{l}\text { Wet impregnation of } \mathrm{CeO}_{2} \text { with } \mathrm{Ni}\left(\mathrm{NO}_{3}\right)_{2} \cdot 6 \mathrm{H}_{2} \mathrm{O} \text { and } \\
\mathrm{ZrO}\left(\mathrm{NO}_{3}\right)_{2} \cdot \mathrm{xH}_{2} \mathrm{O} \text { aqueous solutions }\end{array}$ & 43.4 & 0.3 & 0 & [18] \\
\hline $\begin{array}{l}24.1 \mathrm{wt} . \% \mathrm{Ni}-26.1 \\
\text { wt.\% } \mathrm{Mg}-49.8 \mathrm{wt} . \% \mathrm{Al}\end{array}$ & $1 \mathrm{~atm}, 400-600^{\circ} \mathrm{C}$ & $\begin{array}{l}\text { Co-precipitation method with rising pH technique } \\
\text { using } \mathrm{Ni}\left(\mathrm{NO}_{3}\right)_{2} \cdot 6 \mathrm{H}_{2} \mathrm{O}, \mathrm{Al}\left(\mathrm{NO}_{3}\right)_{3} \cdot 9 \mathrm{H}_{2} \mathrm{O} \text { and } \\
\mathrm{Mg}\left(\mathrm{NO}_{3}\right)_{2} \cdot 6 \mathrm{H}_{2} \mathrm{O} \text { aqueous solutions }\end{array}$ & 37.8 & $\begin{array}{l}1.0 \\
(\mathrm{WGFR}=9)\end{array}$ & 0 & [24] \\
\hline 15 wt. $\% \mathrm{Ni} / \mathrm{CeO}_{2}$ & $1 \mathrm{~atm}, 400-700^{\circ} \mathrm{C}^{\mathrm{c}}$ & $\begin{array}{l}\text { Deposition-precipitation using } \mathrm{Ni}\left(\mathrm{NO}_{3}\right)_{2} \cdot 6 \mathrm{H}_{2} \mathrm{O} \\
\text { aqueous solution }\end{array}$ & 36.5 & n.d. ${ }^{d}$ & n.d. ${ }^{d}$ & [50] \\
\hline 15 wt. $\% ~ N i / \mathrm{Al}_{2} \mathrm{O}_{3}$ & $1 \mathrm{~atm}, 450-550^{\circ} \mathrm{C}$ & $\begin{array}{l}\text { Wet impregnation of } \mathrm{Y}-\mathrm{Al}_{2} \mathrm{O}_{3} \text { with } \mathrm{Ni}\left(\mathrm{NO}_{3}\right)_{2} \cdot 6 \mathrm{H}_{2} \mathrm{O} \\
\text { aqueous solution }\end{array}$ & 59.8 & $\begin{array}{l}0.48 \\
(30-60 w t . \%)\end{array}$ & $\begin{array}{l}0.34 \\
(40-70 w t . \%)\end{array}$ & [134] \\
\hline $\mathrm{Ni} / \mathrm{CeO}_{2}{ }^{\mathrm{c}}$ & $1 \mathrm{~atm}, 600-650^{\circ} \mathrm{C}$ & $\begin{array}{l}\text { Wet impregnation of } \mathrm{CeO}_{2} \text { with } \mathrm{Ni}\left(\mathrm{NO}_{3}\right)_{2} \cdot 6 \mathrm{H}_{2} \mathrm{O} \\
\text { aqueous solution }\end{array}$ & 103.4 & 0.23 & 0 & [135] \\
\hline 15 wt. $\% \mathrm{Co} / \mathrm{Al}_{2} \mathrm{O}_{3}$ & $1 \mathrm{~atm}, 450-550^{\circ} \mathrm{C}$ & $\begin{array}{l}\text { Wet impregnation of } \mathrm{Al}_{2} \mathrm{O}_{3} \text { with } \mathrm{Co} \\
\left(\mathrm{NO}_{3}\right)_{2} \cdot 6 \mathrm{H}_{2} \mathrm{O} \text { aqueous solution }\end{array}$ & 67.2 & $\begin{array}{l}0.08 \\
(30-60 w t . \%)\end{array}$ & $\begin{array}{l}0.39 \\
(40-70 w t . \%)\end{array}$ & [107] \\
\hline $\begin{array}{l}5 \text { wt.\% } \mathrm{Co}-10 \text { wt.\% } \\
\mathrm{Ni} / \mathrm{Al}_{2} \mathrm{O}_{3}\end{array}$ & $1 \mathrm{~atm}, 500-550^{\circ} \mathrm{C}$ & $\begin{array}{l}\mathrm{Co} \text {-impregnation of } \mathrm{Al}_{2} \mathrm{O}_{3} \text { with } \mathrm{Co}\left(\mathrm{NO}_{3}\right)_{2} \cdot 6 \mathrm{H}_{2} \mathrm{O} \text { and } \\
\mathrm{Ni}\left(\mathrm{NO}_{3}\right)_{2} \cdot 6 \mathrm{H}_{2} \mathrm{O} \text { aqueous solutions }\end{array}$ & 63.3 & $\begin{array}{l}0.25 \\
(4.5-16.5 \mathrm{kPa})\end{array}$ & (25-88 kPa) & [108] \\
\hline $\mathrm{Pt} / \mathrm{C}$ & $5 \mathrm{~atm}, 350-400^{\circ} \mathrm{C}$ & $\begin{array}{l}\text { Supplied } \\
\text { by Arora-Matthey Ltd., Kolkata }\end{array}$ & n.d. ${ }^{d}$ & $\begin{array}{l}1.0 \\
(10-34 \mathrm{kPa})\end{array}$ & 0 & [89] \\
\hline $5 \% \mathrm{Ru} / \mathrm{Al}_{2} \mathrm{O}_{3}$ & $1 \mathrm{~atm}, 350-500{ }^{\circ} \mathrm{C}$ & Supplied by Johnson-Matthey Ltd., Delhi. & 21.2 & $\begin{array}{l}1.0 \\
\left(\mathrm{x}_{\mathrm{G}}=0.068\right. \\
0.091)\end{array}$ & 0 & [114] \\
\hline
\end{tabular}

a - Temperature and total pressure at which the experiments were carried out;

$\mathrm{b}$ - The values between brackets are the ranges of each species in the feed or their partial pressure;

c - Metal loading not specified;

d n.d.: not determined. 
Table 9 - Sorption capacities and sorption/regeneration temperatures of several $\mathrm{CO}_{2}$ sorbents reported in the literature for SERs applications.

\begin{tabular}{|c|c|c|c|c|c|c|}
\hline $\begin{array}{l}\text { K-doped hydrotalcite (20 wt.\% } \\
\mathrm{K}_{2} \mathrm{CO}_{3} \text { and } \mathrm{Mg} / \mathrm{Al} \text { ratio }=2 \text { ) }\end{array}$ & $9.40^{a}$ & 300 & 600 & 0.34 & 4.5 & [141] \\
\hline Hydrotalcite & 1.18 & 400 & n.s. & 0.15 & 0 & [164] \\
\hline $\begin{array}{l}\text { Ga-K-doped hydrotalcite (10 } \\
\text { wt.\% Ga and } 20 \text { wt.\% K) }\end{array}$ & 1.82 & 300 & 300 & 1.08 & 0 & [165] \\
\hline $\mathrm{CaO}-\mathrm{Y}_{2} \mathrm{O}_{3}\left(20\right.$ wt. $\left.\% \mathrm{Y}_{2} \mathrm{O}_{3}\right)$ & 12.95 & 850 & 850 & n.s. ${ }^{b}$ & 0 & [147] \\
\hline $\mathrm{Li}_{2} \mathrm{ZrO}_{3}$ & $5.00^{a}$ & 500 & n.s. & n.s. ${ }^{\text {bc }}$ & n.s. ${ }^{b c}$ & [153] \\
\hline $\begin{array}{l}\text { K-doped } \mathrm{Li}_{4} \mathrm{SiO}_{4} \text { (30 wt.\% } \\
\mathrm{K}_{2} \mathrm{CO}_{3} \text { ) }\end{array}$ & 5.23 & 580 & 700 & 0.04 & 0 & [156] \\
\hline $\begin{array}{l}\mathrm{Li}_{4} \mathrm{SiO}_{4} \text { (treated with glacial } \\
\text { acetic acid) }\end{array}$ & 0.77 & 550 & 625 & 0.1 & 0 & {$[157]$} \\
\hline
\end{tabular}

a Wet conditions;

b n.s.: not specified;

c - Total pressure $=4.47 \mathrm{bar}$. 
Table 10 - Characteristics of different Pd-based membranes reported in the literature.

\begin{tabular}{|c|c|c|c|c|c|c|c|}
\hline Membrane & $T\left({ }^{\circ} \mathrm{C}\right)^{\mathrm{a}}$ & $\Delta P(\mathrm{kPa})^{\mathrm{b}}$ & $\begin{array}{l}\delta \\
(\mu \mathrm{m})\end{array}$ & $\begin{array}{l}\text { Permeance to } \mathrm{H}_{2} \\
\left(\mathrm{~mol} \cdot \mathrm{m}^{-2} \cdot \mathrm{s}^{-1} \cdot \mathrm{Pa}^{-0.5}\right)\end{array}$ & $\begin{array}{l}\text { Ideal selectivity } \\
\mathrm{H}_{2} / \mathrm{N}_{2}\end{array}$ & $\begin{array}{c}E_{a, P d} \\
\left(\mathrm{~kJ} \cdot \mathrm{mol}^{-1}\right)\end{array}$ & Reference \\
\hline $\mathrm{Pd}-25$ wt.\% Ag & 300 & $10-150$ & 50 & $1.15 \times 10^{-4 c}$ & $\infty$ & 10.72 & {$[180]$} \\
\hline Pd-23-25 wt.\% Ag & 350 & 700 & 84 & $2.26 \times 10^{-4 c}$ & $\infty$ & 2.92 & [181] \\
\hline $\mathrm{Pd}_{46.6}-\mathrm{Cu}_{53.4}$ & 400 & 345 & 40 & $4.50 \times 10^{-4 c}$ & - & 5.80 & [182] \\
\hline $\mathrm{Pd}_{45.8}-\mathrm{Cu}_{51.9}-\mathrm{Ag}_{2.3}$ & 400 & 345 & 40 & $3.50 \times 10-4^{c}$ & - & 10.20 & [182] \\
\hline Pd-5 wt.\% Pt/YSZ & 400 & $\begin{array}{l}57.9- \\
609.5\end{array}$ & 6.6 & $1.18 \times 10^{-3 c}$ & 994 & - & [183] \\
\hline $\mathrm{Pd} / \mathrm{Ag} / \mathrm{PSS}$ & 400 & 100 & 4.0 & $1.71 \times 10^{-3 c}$ & 1000 & 11.90 & [184] \\
\hline Pd/Pencil/PSS & 450 & 100 & 7.0 & $1.40 \times 10^{-3 c}$ & 120 & 13.80 & [185] \\
\hline $\mathrm{Pd} / \mathrm{TiO}_{2} / \mathrm{Ti}-\mathrm{Al}$ & 500 & $588-704^{c}$ & 14.0 & $1.07 \times 10^{-3}$ & $\infty$ & 13.65 & [186] \\
\hline $\mathrm{Pd}_{78} \mathrm{Ag}_{9} \mathrm{Au}_{13}$ & 450 & - & 14.0 & $1.16 \times 10^{-3 c}$ & - & - & [187] \\
\hline $\mathrm{Ti}_{50.864} \mathrm{Ni}_{46.961} \mathrm{Pd}_{4.175}$ & 450 & 100 & 45.0 & $3.84 \times 10^{-6 c}$ & - & 42.23 & [188] \\
\hline $\mathrm{Pd}_{95} \mathrm{Au}_{5}$ & 400 & - & 2.5 & $4.40 \times 10^{-3 c}$ & $\geq 10000$ & - & [189] \\
\hline $\mathrm{Pd}_{95} \mathrm{Y}_{5}$ & 400 & - & 2.0 & $5.50 \times 10^{-3 c}$ & $\geq 10000$ & - & [189] \\
\hline $\mathrm{Pd}_{73} \mathrm{Cu}_{26} \mathrm{Y}_{1}$ & 400 & - & 2.0 & $2.50 \times 10^{-3 c}$ & $\geq 10000$ & - & [189] \\
\hline
\end{tabular}

b Trans-membrane pressure difference at which the permeance was obtained;

c Calculated values. 